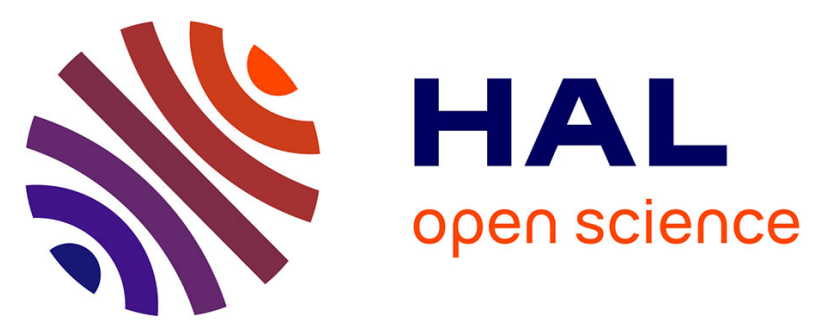

\title{
Neurotensin receptor 2 is induced in astrocytes and brain endothelial cells in relation to status epilepticus and neuroinflammation following pilocarpine administration in rats
}

Kyriatzis Grigorios, Bernard Anne, Bôle Angélique, Pflieger Guillaume, Chalas Petros, Masse Maxime, Lécorché Pascaline, Jacquot Guillaume, Ferhat Lotfi, Michel Khrestchatisky

\section{- To cite this version:}

Kyriatzis Grigorios, Bernard Anne, Bôle Angélique, Pflieger Guillaume, Chalas Petros, et al.. Neurotensin receptor 2 is induced in astrocytes and brain endothelial cells in relation to status epilepticus and neuroinflammation following pilocarpine administration in rats. 2020. hal-03073954

\author{
HAL Id: hal-03073954 \\ https://hal.science/hal-03073954
}

Preprint submitted on 16 Dec 2020

HAL is a multi-disciplinary open access archive for the deposit and dissemination of scientific research documents, whether they are published or not. The documents may come from teaching and research institutions in France or abroad, or from public or private research centers.
L'archive ouverte pluridisciplinaire HAL, est destinée au dépôt et à la diffusion de documents scientifiques de niveau recherche, publiés ou non, émanant des établissements d'enseignement et de recherche français ou étrangers, des laboratoires publics ou privés. 


\section{Neurotensin receptor $\mathbf{2}$ is induced in astrocytes and brain endothelial cells in relation to} status epilepticus and neuroinflammation following pilocarpine administration in rats

Running title : Induced astroglial NTSR2 in epilepsy

Kyriatzis Grigorios ${ }^{1}$, Bernard Anne ${ }^{1}$, Bôle Angélique ${ }^{1}$, Pflieger Guillaume ${ }^{1}$, Chalas Petros ${ }^{1}$, Masse Maxime ${ }^{2}$, Lécorché Pascaline ${ }^{2}$, Jacquot Guillaume ${ }^{2}$, Ferhat Lotfi ${ }^{1 *}$ and Khrestchatisky Michel $^{1 *}$

1) Aix-Marseille Univ, CNRS, INP, Inst Neurophysiopathol, Marseille, France

2) VECT-HORUS, Faculté de Médecine, 27 Bd Jean Moulin, 13385 Marseille Cedex 5, France

* Equally last and corresponding authors: lotfi.ferhat@univ-amu.fr and michel.khrestchatisky@univ-amu.fr

\section{WORD COUNT}

Abstract: 242

Introduction: 919

Materials and Methods: 3511

Results: 4965

Discussion: 3146

References: 4183

Figure legends: 2262

\section{MAIN POINTS}

Epilepsy is associated with increased NTSR2 expression in astrocytes and endothelial cells. Proinflammatory factors induce NTSR2 in astroglia with immediate early gene response. A neurotensin analog down regulates NTSR2 and glial cell inflammation. 


\section{ACKNOWLEDGEMENTS}

This work was supported by a fellowship to GK from the European Union's Horizon 2020 research and innovation program under the Marie Sklodowska-Curie grant agreement No 642881, and AMIDEX (ICN PhD Program, ANR-11-IDEX-0001-02 grant) funded by the French Government «Investissements d'Avenir» program. Funding from the CNRS and AixMarseille Université (AMU) to the Institute of Neurophysiopathology (INP), UMR7051 is acknowledged. We thank Fanny Gassiot for her expertise in VH-N412 synthesis and Antoine Ghestem for advice on the rat pilocarpine model. We are grateful to Dr. Jean-Pierre Kessler and Dr. Fabien Tell for helpful discussions and sharing lab space and equipment. We also thank Stéphane Girard, Christophe Fraisier, and Yasmine Mechioukhi (all from Vect-Horus SAS, Marseille) for providing PDGFRß, CD31 and CollV antibodies. Last, we thank Dr. Mourad Mekaouche and Axel Fernandez for advice and help with animal care, as well Yves Gobin for laboratory assistance.

\section{CONFLICT OF INTERESTS STATEMENT}

MK is director of the Institute of Neurophysiopathology, UMR7051, an academic neuroscience laboratory supported by the CNRS and Aix-Marseille University, but also cofounder, shareholder and scientific counsel of the VECT-HORUS biotechnology company. 


\section{ABSTRACT}

Neurotensin (NT) acts as a primary neurotransmitter and neuromodulator in the CNS and has been involved in a number of CNS pathologies including epilepsy. NT mediates its central and peripheral effects by interacting with the NTSR1, NTSR2 and NTSR3 receptor subtypes. To date, little is known about the precise expression of the NT receptors in brain neural cells and their regulation in pathology. In the present work, we studied expression of the NTSR2 protein in the rat hippocampus using a model of temporal lobe epilepsy induced by pilocarpine and questioned whether NTSR2 was modulated in conditions of neuroinflammation. This model is characterized by a rapid and intense inflammatory reaction with a pattern of reactive gliosis in the hippocampus. We show that NTSR2 protein is expressed in hippocampal astrocytes and its expression increases together with astrocyte reactivity following induction of status epilepticus. NTSR2 immunoreactivity is also increased in perivascular astrocytes and their end-feet and is apparent in endothelial cells following induction of status epilepticus. Proinflammatory factors such as IL1 $\beta$ and LPS induced NTSR2 in astrocytes, but also in microglia in vitro. Glial NTSR2 expression showed characteristic immediate early gene response under inflammatory conditions. Treating inflamed glial cells with a vectorized NT analogue decreased NTSR2 expression as well as astrocytic and microglial reactivity. Together, these results suggest that NTSR2 is implicated in astroglial and gliovascular inflammation and that targeting the NTSR2 receptor may open new avenues in the regulation of neuroinflammation in CNS diseases.

\section{KEYWORDS}

NT, NTS, NTSR2, seizures, epilepsy, microglia, endothelial cells, blood-brain barrier, immediate early gene 
bioRxiv preprint doi: https://doi.org/10.1101/2020.06.29.166637; this version posted June 29, 2020. The copyright holder for this preprint (which was not certified by peer review) is the author/funder. All rights reserved. No reuse allowed without permission.

\section{TABLE OF CONTENTS IMAGE}

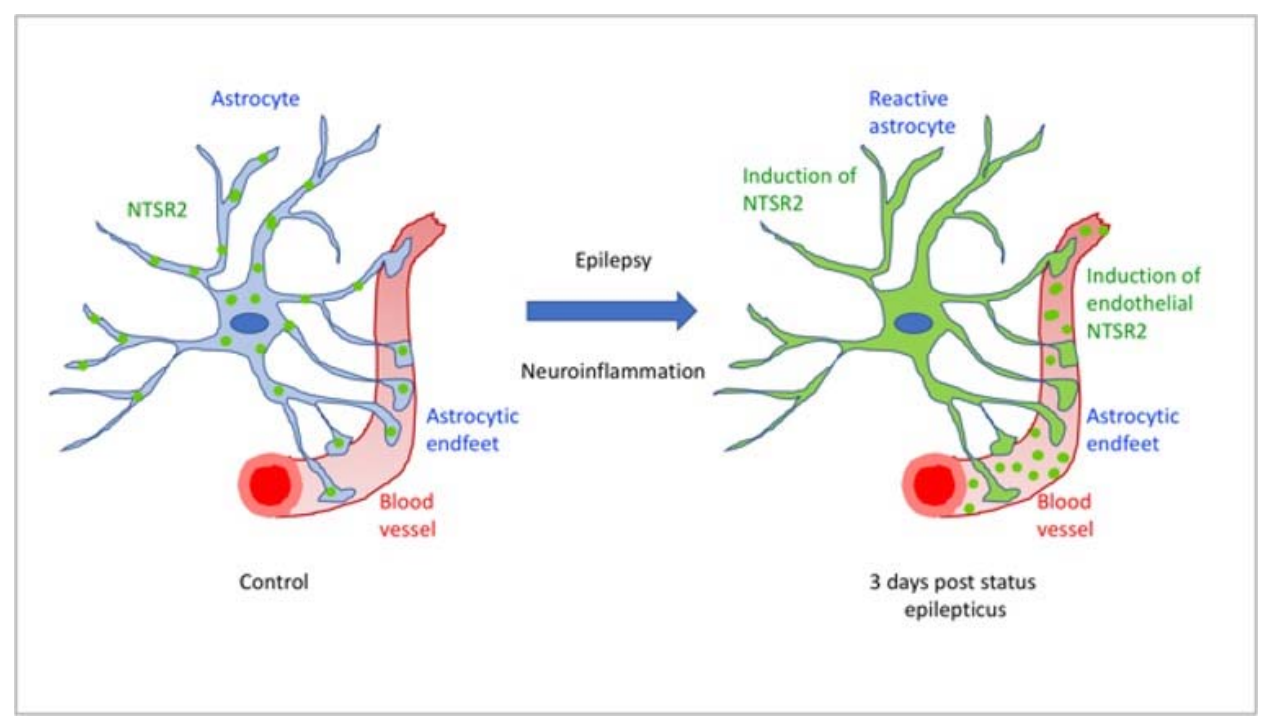




\section{INTRODUCTION}

Neurotensin (NT) is a tridecapeptide highly conserved between species. In the periphery it is expressed in the gastrointestinal tract where it acts as a hormone, influencing food intake, body weight gain and the control of energy homeostasis. In the CNS, NT is a primary neurotransmitter/neuromodulator that mediates analgesia and is implicated in memory consolidation and in learning processes (Goedert and Emson, 1983; Vincent, 1995; Friry et al., 2002; Devader et al., 2006; Yamauchi et al., 2007). NT has been involved in a number of psychiatric pathologies, distinctively schizophrenia (Sharma et al., 1997), eating disorders (Hawkins et al., 1986), Parkinson's disease (Hernandez-Chan et al., 2015), glioma (Ouyang et al., 2015), pain (Williams et al., 1995), cerebral ischemia (Torup et al., 2003) and epilepsy (Lee et al., 2009; St-Gelais et al., 2006). Previous studies have interrelated NT and seizures. Indeed, in the KA model of epilepsy, NT-like immunoreactivity in the rat hippocampus was reduced after onset of seizures, suggesting NT release (Sperk et al., 1986). Intracerebroventricular (i.c) or intraperitoneal (i.p) administration of NT or its analogues showed anti-convulsant effects in a corneal stimulation mouse model of pharmaco-resistant epilepsy (Lee et al., 2009; Green et al., 2010). However, the mechanism by which NT receptors (NTSRs) mediate anti-convulsive effects remains unknown. NT and its analogues induce generalized hypothermia of $2-4^{\circ} \mathrm{C}$ when administered directly in the CNS by intracisternal or i.c administration (Nemeroff et al., 1980). This reduction in body temperature prevents hippocampal neuronal damage and preserves locomotor activity during an ischemic insult, highlighting NT's therapeutic potential (Babcock et al., 1993).

Recently, we showed that intravenous (i.v) administration of NT analogues vectorized with a brain shuttle peptide targeting the blood brain barrier LDL receptor induced potent neuroprotective and anti-neuroinflammatory effects in the hippocampus of a rodent model of epilepsy. These neuroprotective effects of NT on hippocampal neurons were probably mediated by hypothermia, in vivo, but we demonstrated they could also be observed in vitro, independently of hypothermia (Soussi et al., manuscript in preparation).

NT mediates its central and peripheral effects by interacting with three receptor subtypes, namely NTSR1, NTSR2 and NTSR3. NTSR1 and NTSR2 are G protein-coupled 
receptors with seven transmembrane domains (Vincent, 1995). NTSR3 or gp95/Sortilin 1 is a type I receptor with a single transmembrane domain that belongs to the Vps10p-containing domain receptor family and is not coupled to a $G$ protein (Mazella, 2001). To date, not much is known on the potential role of NT in modulating neuroprotection and neuroinflammation and which receptors are involved, in which brain structures and cell types. NTSR1 and NTSR2 show high and low affinity for NT, respectively (Tanaka et al., 1990; Chalon et al., 1996), and these two receptors are found in different cell types of the nervous system at different developmental stages. NTSR1 is expressed prenatally in many rat brain structures. Expression peaks shortly after birth and is decreased in adulthood (Palacios et al., 1988). On the other hand, NTSR2 expression is essentially postnatal and increases progressively with age (Sarret et al., 1998; Lépée-Lorgeoux et al., 1999), raising interest on the role of this receptor in brain physiopathology.

NTSR2 is a $45 \mathrm{kDa}$ protein in humans and rodents, endowed with lower affinity for NT compared to NTSR1 ( $\mathrm{Kd}=3-10 \mathrm{nmol} / \mathrm{L}$ compared to $0.1-0.3 \mathrm{nmol} / \mathrm{L}$ for NTSR1) (St-Gelais et al., 2006). Besides its expression in pancreatic $\beta$ cells (Béraud-Dufour et al., 2009) and human B lymphocytes (Saada et al., 2012), NTSR2 is essentially expressed in the CNS, including the hippocampus, cerebral cortex, cerebellum, olfactory bulb, substantia nigra, and ventral tegmental area (Walker et al., 1998; Lépée-Lorgeoux et al., 1999; Sarret et al., 2003). Globally, NTSR2 exerts the same effects as NTSR1 with a more characterized role in painreducing modulation (reviewed in Kleczkowska and Lipkowski, 2013) and fear memory (Yamauchi et al., 2007). Rat NTSR2 mRNA expression was shown in astrocytes in vivo (Walker et al., 1998; Yamauchi et al., 2007), and NTSR2 protein immunofluorescence was reported in astrocytes in the ventral tegmental area in mice (Woodworth et al., 2018). In contrast, other studies reported no NTSR2 immunostaining in astrocytes in adult rat brain (Sarret et al., 2003). Thus, the neurocellular expression of NTSR2 remains controversial, and up to now, the data available is limited.

In the present work, we assessed the expression of NTSR2 in the hippocampus, both in physiological and pathological conditions. In particular, we questioned whether expression of the NTSR2 receptor was modulated in conditions of neuroinflammation using a pathophysiological model of TLE induced by pilocarpine in adult rats. In this model, animals 
undergo a rapid and intense neuroinflammatory reaction with a pattern of reactive gliosis in the hippocampus involving the activation of microglia and astrocytes (Clifford et al., 1987; Garzillo \& Mello, 2002).

Our study shows for the first time unambiguous expression of NTSR2 protein in hippocampal astrocytes of the adult rat, both in vivo and in vitro. In the pilocarpine epileptic rat model, NTSR2 expression was increased rapidly when neuroinflammation peaks, and decreased at the chronic phase (3 months), when astrocyte reactivity subsides (Garzillo and Mello, 2002; Choi and Koh, 2008). NTSR2 was found also to be expressed in microglial cells in vitro but not in vivo. We also report increased NTSR2 expression in blood vessels during inflammation and showed that a NT analogue that elicits anti-neuroinflammation effects in vivo downregulated glial reactivity in vitro. In all, our work demonstrates the involvement of the neurotensinergic system in parenchymal astrocytes and in the glio-vascular unit during neuroinflammation and suggest that targeting the NTSR2 receptor could modulate neuroinflammation. 


\section{MATERIALS AND METHODS}

\section{Experimental Animals}

All experimental procedures involving rats and mice were approved by National and European regulations (EU directive $\mathrm{N}^{\circ}$ 2010/63) and in agreement with the authorization for animal experimentation attributed to the laboratory by the Prefecture des Bouches du Rhône (permit number: D 13055 08) and to the project ( $\mathrm{N}^{\circ}$ 00757.02) by the French Ministry of Research and Local Ethics Committee. Animals were maintained in the animal facility with $12 \mathrm{H}$ light-dark cycles, had access to food and water ad libitum and were treated according to Appendix $A$ of the European Convention for the Protection of Vertebrate Animals used for Experimental and other Scientific Purposes, ETS No. 123. All efforts were made to minimize animal suffering and to reduce the number of animals used.

\section{Rat pilocarpine model}

Adult male Wistar rats weighing 200-290 g (Charles River, France) were first injected i.p. with a low dose of the cholinergic antagonist scopolamine methyl nitrate $(2 \mathrm{mg} / \mathrm{kg}$; Sigma, Saint Louis, MO, USA), in order to minimize the peripheral effects of pilocarpine hydrochloride (320 mg/kg; Sigma), a muscarinic cholinergic agonist that we diluted in 0,9\% $\mathrm{NaCl}$ and administered i.p.30 min after scopolamine methyl nitrate. Control rats received an injection of $0,9 \% \mathrm{NaCl}$. The injection protocols were similar to those previously described for the generation of TLE (Mello et al., 1993; Obenaus et al., 1993; Dinocourt et al., 2003; Sbai et al., 2012; Soussi et al., 2015). Only animals that developed confirmed SE after the pilocarpine injection were included in the study. To reduce animal mortality, SE was stopped after $1 \mathrm{H}$ by two injections of Diazepam (Valium) with a $15 \mathrm{~min}$ interval $(10 \mathrm{mg} / \mathrm{kg}$, i.p. Roche, France). Pilocarpine-treated animals were then observed periodically for general behavior and occurrence of spontaneous seizures. Pilocarpine-treated animals were studied at several post-injection intervals: during the latent period, when animals displayed an apparently normal behavior ( 3 days, 1 and 2 weeks, $n \geq 6$ at each time point), and during the chronic stage, when the animals developed spontaneous recurrent limbic seizures ( 12 weeks; $n \geq 6$ ). During the following days after induction of SE, animals were nurtured and assisted to drink water. For the weakest ones, a double dose of soluble $\mathrm{NaCl} 0,9 \%$ and glucose $(10 \mathrm{mg} / \mathrm{kg}$, i.p.) was provided twice per day until they regained their weight or reached the endpoint. 
Animals were housed two per cage in enriched environment to minimize stress prior to SE and one per cage to avoid aggressive behaviors post-SE.

\section{Mouse kainic acid model}

As an alternative model of epilepsy, young adult male $\mathrm{FVB} / \mathrm{N}$ mice (Janvier Laboratories, France), 25-30 g, 9-10 weeks old, were injected subcutaneously with a single dose of kainic acid (KA, 40-45 mg/kg; Abcam, France) to generate mice with spontaneous recurrent seizures as a hallmark of SE as previously described (Schauwecker \& Steward, 1997). All animals were housed six per cage. KA-injected mice were individually housed and received a 0,5 $\mathrm{ml}$ i.p. dose of glucose and also had free access to Doliprane (paracetamol, Sanofi, Gentilly, France) at 2,4 \% in agarose gel in order to reduce pain. Mice were observed during $9 \mathrm{H}$ for onset and extent of seizure activity and only mice developing typical SE were included in the study. Body weight was monitored daily.

\section{Tissue Preparation}

Rats were deeply anesthetized with pentobarbital sodium injection (Nembutal, 120 $\mathrm{mg} / \mathrm{kg}$, i.p., Ceva, France) and perfused through the heart with a fixative paraformaldehydebased solution (Antigenfix, Diapath, Italy). The brains were then removed from the skull $30 \mathrm{~min}$ later, and were post-fixed in the same fixative solution for $24 \mathrm{H}$ at $4^{\circ} \mathrm{C}$. Finally, brains were rinsed $3 x$ in Phosphate Buffer (0,12 M; PB, pH 7,2-7,4) and cryoprotected in 30\% sucrose solution in PB 0,12 M until fully dehydrated (indicated by sinking of the brain at the bottom of the pot, lasting from 2-4 days). Brains were first frozen in isopentane solution (Sigma) at $-80^{\circ} \mathrm{C}$ and then fixed in O.C.T. Tissue Tek (Sakura Finetek, Torrance, CA, USA) and sectioned coronally at $40 \mu \mathrm{m}$ with a cryostat. The sections were collected sequentially in wells of culture plates containing an ethylene glycol-based cryoprotective solution and stored at $-20^{\circ} \mathrm{C}$ until processing. Selected sections from each rat covering the dorsal hippocampus (from bregma $-3,30$ to $-4,80 \mathrm{~mm}$ according to the rat brain Atlas (Paxinos \& Watson, 1998), were used for immunohistochemical staining. Free-floating sections from control (CTL) and pilocarpine-treated rats (PILO) were always processed in parallel.

Mice were deeply anesthetized with chloral hydrate $(700 \mathrm{mg} / \mathrm{kg}$; ProLabo, France) and transcardially perfused with Antigenfix solution. The brains were extracted and post- 
fixed for $1 \mathrm{H}$ at room temperature (RT) and rinsed in PB $0.12 \mathrm{M}$. Forty $\mu \mathrm{m}$ coronal sections were generated using a vibratome, immersed in a cryoprotective solution and stored at $20^{\circ} \mathrm{C}$ until use for immunofluorescence. From each mouse, selected sections from the dorsal hippocampus (bregma -1,55 to -2,35 according to the mouse brain Atlas (Paxinos \& Franklin, 2019)), were processed for immunohistochemistry. Mice were sacrificed at 7 days post-SE (KA 7D) and free-floating sections from CTL and KA-treated mice were processed in parallel.

\section{Immunohistochemistry}

\section{Double immunofluorescence labeling for NTSR2 and GFAP/Iba1}

For double labeling of primary antibodies originating from the same host species, in our case rabbit, a protocol from Jackson Immunoresearch was used and optimized for our purposes. Free-floating sections from CTL and pilocarpine-treated rats (PILO rats) from the dorsal hippocampus were processed in parallel. References of primary antibodies used in this study are summarized in Table 1. Free-floating sections were permeabilized in a solution containing 3\% Bovine Serum Albumin (BSA) and 0,3\% Triton X-100 in PB 0,12 M for $1 \mathrm{H}$ at RT. Following permeabilization, sections were first incubated overnight at $4{ }^{\circ} \mathrm{C}$ with rabbit antiNTSR2 diluted in a blocking solution containing 3\% BSA diluted in PB 0,12 M. The next day, slices were washed three times in PB 0,12 M under agitation and incubated with secondary antibody, goat anti-rabbit biotin (1:200) (Life Technologies, France) diluted in the blocking solution for $2 \mathrm{H}$, and then revealed with streptavidin IgG conjugated with AlexaFluor 488 (Jackson Immunoresearch, West Grove, PA, USA) diluted in blocking solution (1:800) for $2 \mathrm{H}$, in dark. Next, slices were washed three times in PB 0,12 $\mathrm{M}$ and incubated with normal rabbit serum (1:20) (Jackson Immunoresearch) diluted in PB 0,12 M for $2 \mathrm{H}$ at $\mathrm{RT}$, in dark, to saturate open binding sites on the first secondary antibody with IgG. Following three washes in PB $0.12 \mathrm{M}$, slices were incubated with unconjugated Fab goat anti-rabbit IgG $(\mathrm{H}+\mathrm{L})(20$ $\mu \mathrm{g} / \mathrm{mL}$ ) (Jackson Immunoresearch) diluted in PB 0,12 M for $2 \mathrm{H}$ at RT, in dark, to cloak the rabbit IgG and hamper binding of the second secondary antibody. Afterwards, slices were incubated overnight in the dark at $4^{\circ} \mathrm{C}$ under agitation with rabbit anti-GFAP or rabbit antiIba1. The last day, slices were washed three times in PB 0,12 M and incubated with a goat anti-rabbit IgG $(\mathrm{H}+\mathrm{L})$ highly cross-adsorbed AlexaFluor A594 (1:1.000, Life Technologies) diluted in blocking solution for $2 \mathrm{H}$, in dark. Nuclei were counterstained with $5 \mu \mathrm{g} / \mathrm{mL}$ 4?,6Diamidino-2-phenylindole (DAPI, Sigma) for $0,5 \mathrm{H}$ at RT, in dark. After three washes in PB 
$0,12 \mathrm{M}$, floating sections were mounted on Superfrost Plus glass slides using Fluoromount-G Mounting medium (Electron Microscopy Sciences, Hatfield, PA, USA) and stored at $-20^{\circ} \mathrm{C}$ until imaging and analysis. The specimens were then analyzed using a confocal microscope (Zeiss, LSM 700, Jena, Germany) and images were acquired using Zen software (Zeiss), and processed using Adobe Photoshop and ImageJ softwares.

The specificity of the double immunohistochemical labeling for antibodies originating from the same host such as NTSR2 and GFAP or Iba1 was tested by incubating some sections from CTL and pilocarpine-treated animals with two primary antibodies with different targets; GFAP (rabbit, for astrocytes) and Iba1 (rabbit, for microglia). The two antibodies gave a clearly distinctive specific pattern and did not overlap. To judge the efficiency of the blocking, the second primary antibody was omitted, but not the corresponding secondary antibody. In all cases, the second secondary antibody did not detect the first primary antibody. Additional controls included incubation of some sections in a mixture of one primary antibody and biotinylated rabbit normal IgG, or rabbit normal IgG. The pattern of immunolabeling of these sections was the same as for sections processed for single labeling.

\section{Triple immunofluorescence labeling for CollV, CD31, NTSR2}

Following permeabilization and blocking, sections were incubated overnight at $4{ }^{\circ} \mathrm{C}$ under agitation with goat anti-CollV diluted in blocking solution. Next day, sections were washed three times in PB 0,12 $\mathrm{M}$ under agitation and then incubated overnight at $4^{\circ} \mathrm{C}$ with the other two primary antibodies, mouse anti-CD31 and rabbit anti-NTSR2, sequentially (i.e. one per day). The fourth day, sections were washed three times in PB 0,12 M under agitation and then incubated for $2 \mathrm{H}$, in the dark with the appropriate secondary antibodies: donkey anti-goat IgG $(\mathrm{H}+\mathrm{L})$ highly cross-adsorbed AlexaFluor A488 for CollV, donkey antimouse IgG $(\mathrm{H}+\mathrm{L})$ highly cross-adsorbed AlexaFluor A594 for CD31 and donkey anti-rabbit IgG $(\mathrm{H}+\mathrm{L})$ highly cross-adsorbed AlexaFluor A647 for NTSR2 (Life Technologies), diluted in blocking solution at 1:800. Slices were then washed three times in PB 0,12 M under agitation and nuclei were counterstained with $5 \mu \mathrm{g} / \mathrm{mL}$ DAPI for $0,5 \mathrm{H}$ at RT, in dark. Finally, sections were mounted using Fluoromount-G Mounting medium and stored at $-20^{\circ} \mathrm{C}$. The specificity of the triple immunohistochemical labeling was validated by incubating some sections in a solution omitting the primary antibodies in the presence of the appropriate secondary 
antibodies. No staining was detected under these conditions.

\section{Triple immunofluorescence labeling PDGFR $\beta$, CD31, NTSR2}

For the immunostaining of PDGFR $\beta$ and NTSR2, sections were processed as for NTSR2 and GFAP/Iba1 immunostaining. Briefly, sections were incubated with rabbit anti-PDGFR $\beta$ and the next day after several rinses in PB 0,12 M, they were incubated sequentially with goat anti-rabbit biotin, streptavidin IgG conjugated with AlexaFluor A488 (Jackson Immunoresearch), normal rabbit serum, Fab goat anti-rabbit IgG, and finally incubated with rabbit anti-NTSR2 overnight at $4^{\circ} \mathrm{C}$. The third day, following three washes in PB 0,12 M, slices were incubated with mouse anti-CD31 overnight. The last day, slices were washed three times and incubated with goat anti-mouse IgG1 $(\mathrm{H}+\mathrm{L})$ cross-adsorbed AlexaFluor A594 (1:800) for CD31, and goat anti-rabbit IgG $(\mathrm{H}+\mathrm{L})$ highly cross-adsorbed AlexaFluor A647 (1:1.000) (Life Technologies) in blocking solution for $2 \mathrm{H}$, in dark. Nuclei were counterstained with DAPI and sections were mounted using Fluoromount-G Mounting medium and stored at $-20^{\circ} \mathrm{C}$. The specificity of the triple immunohistochemical labeling was tested as described above. In all cases, no specific staining was detected under these conditions.

\section{Double immunofluorescence labeling for NTSR2 and MAP2}

Sections were incubated overnight at $4^{\circ} \mathrm{C}$ under agitation with rabbit anti-NTSR2 diluted in blocking solution. Next day, they were washed three times in PB 0,12 M under agitation and incubated overnight at $4^{\circ} \mathrm{C}$ with chicken anti-MAP2. The last day, sections were washed 3 times in PB 0,12 M under agitation and then incubated for $2 \mathrm{H}$, in the dark with the appropriate secondary antibodies: goat anti-rabbit $\lg G(\mathrm{H}+\mathrm{L})$ highly cross-adsorbed AlexaFluor A488 for NTSR2 and goat anti-chicken IgY (H+L) AlexaFluor A594 (Life Technologies) for MAP2 diluted in blocking solution at 1:800. Counterstaining with DAPI, mounting, storage and imaging were as described above.

\section{Primary glial cell cultures}

Glial cells (astrocytes, microglia) were prepared from embryonic day 18 (E18) or newborn (P0) rats cortices. Briefly, rats were killed by decapitation, brains were removed and cortices were dissected out and cleared from the meninges. Pieces of cortices were digested in a Trypsin-EDTA $1 x$ solution for $15 \mathrm{~min}$ at $37^{\circ} \mathrm{C}$ and rinsed three times in HBSS $1 \mathrm{X}$ 
followed by three rinses in Dulbecco's Modified Eagle Medium Glutamax 1X (DMEM) medium supplemented with $10 \%(\mathrm{v} / \mathrm{v}$ ) heat-inactivated Fetal Bovine Serum (FBS). Next, cortices were mechanically dissociated by successive pipetting in DMEM supplemented with FBS. Dissociated cells were grown in DMEM supplemented with $10 \%$ FBS and 100 i.u./mL penicillin/streptomycin (all supplements were from Thermo Fisher Scientific, France), in a humidified atmosphere containing $5 \% \mathrm{CO}_{2}$, at $37^{\circ} \mathrm{C}$. The medium was changed twice per week and the cultures were used for experiments after 15 days in culture.

\section{Induction of inflammation and pharmacological treatments in primary glial cultures}

Inflammation in primary glial cultures was induced by the addition of proinflammatory agents such as interleukin 1 beta (IL1 $\beta, 10 \mathrm{ng} / \mathrm{mL}$; PeproTech, France) or lipopolysaccharide (LPS, $1 \mu \mathrm{g} / \mathrm{ml}$; Sigma) for 1,6 , and $24 \mathrm{H}$, at $37^{\circ} \mathrm{C}$. Cultures were also incubated with $1 \mu \mathrm{M} \mathrm{VH}$ $\mathrm{N} 412$ for $24 \mathrm{H}$ in the presence or absence of IL1 $\beta$ or LPS. For studies of immediate-early gene responses, primary glial cultures were incubated with the protein synthesis inhibitor, cycloheximide ( $\mathrm{CHX}, 10 \mathrm{\mu g} / \mathrm{ml}$, Cell Signaling Technology, MA, USA) in the presence or absence of LPS for 1,6 , and $24 \mathrm{H}$ at $37^{\circ} \mathrm{C}$. Following treatments, after one wash with $\mathrm{PB} 0,12$ $M$, cells were either fixed with $4 \%$ paraformaldehyde (PFA) in PB 0,12 M for 20 min at RT and then processed for immunocytochemistry, or used for RNA extraction and RT-qPCR analyses.

\section{Immunocytochemistry}

Cell coated coverslips were rinsed three times with PB 0,12 $\mathrm{M}$ and permeabilized in a blocking solution containing 3\% BSA and 0,1\% Triton X-100 diluted in PB 0,12 M for 30 min at RT. Then, coverslips were incubated overnight with rabbit anti-NTSR2 antibody placed on droplets of $50 \mu \mathrm{l}$ of antibody solutions diluted in the $3 \%$ BSA blocking solution with the cells side facing down, inside a humidity chamber at $4^{\circ} \mathrm{C}$. The next day, coverslips were washed three times in PB 0,12 M under agitation at RT and incubated with goat anti-rabbit IgG $(\mathrm{H}+\mathrm{L})$ highly cross-adsorbed AlexaFluor A488 (1:800, Life Technologies) diluted in the blocking solution for $2 \mathrm{H}$, in dark. After three washes in PB 0,12 M, coverslips were incubated with normal rabbit serum (1:20) for $2 \mathrm{H}$ and then with Fab goat anti-rabbit IgG $(20 \mu \mathrm{g} / \mathrm{mL})$ for another $2 \mathrm{H}$ at RT, in dark, before incubation with rabbit anti-GFAP or rabbit anti-lba1 at $4^{\circ} \mathrm{C}$ overnight, in dark. The last day, coverslips were washed three times in PB 0,12 $\mathrm{M}$ and incubated with a goat anti-rabbit IgG $(\mathrm{H}+\mathrm{L})$ highly cross-adsorbed AlexaFluor A594 (1:1.000, 
Life Technologies) antibody diluted in the blocking solution for $2 \mathrm{H}$ at RT, in dark. Nuclei were counterstained with $5 \mu \mathrm{g} / \mathrm{mL}$ DAPI for $0,5 \mathrm{H}$ at RT, in dark. After three washes in PB 0,12 $\mathrm{M}$, coverslips were rapidly rinsed three times in $\mathrm{dH}_{2} \mathrm{O}$ and let to dry in dark, before mounting on Superfrost glass slides using Fluoromount-G Mounting medium and stored at $-20^{\circ} \mathrm{C}$.

Labeling specificity was assessed under the same conditions, by incubating some coverslips from control and treated cells in a solution omitting one of the primary antibodies, and, furthermore, the specificity of the double immunolabeling for antibodies originating from the same host was evaluated by incubating some coverslips with two primary antibodies with different targets, GFAP and Iba1. In all cases, no overlap of antibodies was detected.

\section{MCP-1 (CCL2) assay by ELISA}

Primary glial cell cultures were stimulated with IL1 $\beta(10 \mathrm{ng} / \mathrm{ml})$ or LPS $(1 \mu \mathrm{g} / \mathrm{ml})$ for $24 \mathrm{H}$. Then, supernatants were collected, centrifuged, and stored at $-80^{\circ} \mathrm{C}$ until analysis. Monocyte chemoattractant protein 1/chemokine C-C motif ligand 2 (MCP1/CCL-2) levels were evaluated using a commercially available ELISA kit (PeproTech) according to the manufacturer's instructions. All samples were analyzed in triplicate. The detection threshold was $16 \mathrm{pg} / \mathrm{ml}$ of cytokine.

\section{RNA Extractions and Taq Man quantitative PCR (qPCR)}

Total RNA was prepared from primary rat glial cultures using the Nucleospin RNA plus kit (Macherey Nagel, France). cDNA was synthesized from 500 ng of total RNA using the High Capacity RNA-to-cDNA Kit (Applied Biosystems, CA, USA). For real-time qPCR, 12,5 ng of cDNA were used. The samples were run in duplicate on 96-well plates and then analyzed with 7500 v2.0 software (Applied Biosystems). The conditions of the thermal cycle were as follows: initial denaturation at $95^{\circ} \mathrm{C}$ for 40 cycles, denaturation at $95^{\circ} \mathrm{C}$, and hybridization and extension at $60^{\circ} \mathrm{C}$. Relative expression levels were determined according to the $\Delta \Delta \mathrm{Ct}$ ( $\mathrm{Ct}$ : cycle threshold) method where the expression level of the mRNA of interest is given by $2^{-}$ $\triangle \triangle C T$, where $\triangle \triangle C T=\triangle C t$ target mRNA $-\triangle C$ t reference mRNA (GAPDH, housekeeping gene) in the same sample. PCR experiments were performed with the 7500 Fast Real Time PCR System (Applied Biosystems), according to the manufacturer's recommendations. All 
reactions were performed using TaqMan Fast Universal PCR Mix (Applied Biosystems) and TaqMan Assays (Applied Biosystems) probes (see Table 2).

\section{Synthesis of VH-N412}

VH-N412 (Pr-[CMPipRLRSarC] $]_{c}$-PEG6-RRPYIL-OH) was synthesized by solid phase peptide synthesis method using standard Fmoc/tBu strategy and a Fmoc-Leu-Wang Resin on a Liberty ${ }^{\mathrm{TM}}$ (CEM) microwave synthesizer. In brief, resin-bound peptide was cleaved using a solution comprised of TFA/TIS/ $\mathrm{H}_{2} \mathrm{O} / \mathrm{EDT}$ : $94 / 2 / 2 / 2$ for $2 \mathrm{H}$ at RT. Crude peptide was then precipitated using ice-cold ether, centrifuged at $3000 \mathrm{rpm}$ for $8 \mathrm{~min}$ and lyophilized in $\mathrm{H}_{2} \mathrm{O} / 0.1 \%$ TFA to obtain a white powder. Crude linear Pr-cMPipRLRSarC-PEG6-RRPYIL-OH conjugate was then dissolved in $\mathrm{AcOH} 0.5 \%$ to reach $0.5 \mathrm{mg} / \mathrm{mL}$ final concentration. Ammonium carbonate $(2 \mathrm{~N})$ was added to the conjugate solution to reach an approximate basic $\mathrm{pH}$ of $8-9 . \mathrm{K}_{3}\left[\mathrm{Fe}(\mathrm{CN})_{6}\right](0.01 \mathrm{~N})$ was then added to the reaction mixture until a bright and persistent yellow color was observed to allow mild oxidation conditions. Monitoring of the disulfide bond formation between the two cysteines was performed by analytical RPHPLC. After $30 \mathrm{~min}$, the reaction mixture was filtered over $0.2 \mu \mathrm{M}$ and purified by preparative RP-HPLC. The pull of fractions containing $>95 \%$ pure VH-N412 was freeze-dried to yield a pure white to yellow powder (purity > 95\% assessed by analytical RP-HPLC) and MALDI-TOF (m/z) for C94H163N27024S3, [M+H]+ calc. 2151.15, found 2151,11 Da.

\section{Data analysis}

All acquisitions were performed using a confocal laser-scanning microscope (LSM 700 , Zeiss) through a $\times 20$ or $\times 40$ oil objective and analysis of immunostaining images was performed using ZEN software (Zeiss). To visualize the whole hippocampus, the mosaic function was required. Z-stack function was also useful to determine precisely the coexpression of two markers in the same cells. Finally, ImageJ software (NIH) was used to quantify each immunolabeling. Pictures were binarized to 16 -bit black and white images and a fixed intensity threshold was applied, defining each staining. Images were obtained with double averaging, frame size $1024 \times 1024$, and 1 AU pinhole for each channel.

Quantification of NTSR2 levels in GFAP-positive (GFAP+) cells on tissue. The mean fluorescence intensity (mean grey value) was measured in three different brain regions: 
dentate gyrus $(D G)$, covering the hilus $(H)$, granule cell layer $(G)$, and the inner- and outer molecular layer (IML, OML), CA1, and CA3. Cells were identified as GFAP+ by an apparent nucleus-surrounding structure by co-labeling of NTSR2 with GFAP, and measurement of fluorescence was made in Z-stack x40 acquired images on the stack in which the intensity of NTSR2 was the highest. Measurement of fluorescence was made on the cell body and processes, when these were well defined, by drawing around them. A minimum of 200 GFAP+ cells were analyzed from three pilocarpine-treated animals at each time point and three CTL (2 sections/animal) after subtracting the background fluorescence. Background fluorescence was set in areas devoid of stained cells in the same sections; an average value of 3 such areas was obtained from every image. Data are presented as the mean percentage of fluorescence of NTSR2+ cells co-labeled with GFAP normalized to the controls [mean \pm SEM (standard error of the mean)].

Quantification of NTSR2 levels in blood vessels on tissue. The mean fluorescence intensity was measured in blood vessels of the DG and the lacunosum-moleculare (LM), by drawing and measuring around the inner and outer surface of each vessel. Measurement of fluorescence was made in Z-stack x20 mosaic images on the stack in which the intensity of NTSR2 was the highest. All vessels from three animals from CTL and PILO 3D were quantified (55 and 79 vessels, respectively). Background fluorescence was subtracted. Background fluorescence was set in the stratum radiatum, in areas devoid of brain vessels in the same sections; an average value of three such areas was obtained from every image. Data are presented as the mean percentage of fluorescence of NTSR2+ cells co-labeled with GFAP normalized to the controls (mean \pm SEM).

Quantification of NTSR2, GFAP and Iba1 levels in CTL, inflamed and VH-N412-treated primary glial cultures. The mean fluorescence intensity of NTSR2, GFAP and Iba1 in the cell body and processes was measured in double stained cells for NTSR2 and either GFAP or Iba1. Measurement of fluorescence was made in Z-stack x20 acquired images on the stack where the intensity of each marker was the highest, on isolated cells. A minimum of 100 GFAP+/Iba1+ cells were analyzed for each condition from a total of 10 images/condition spanning the whole coverslip, randomly acquired, from three independent experiments, after subtracting the background fluorescence. Background fluorescence was set in areas 
devoid of cells in every image. Data are presented as the mean percentage of fluorescence of NTSR2 or GFAP/Iba1 in the same cells, normalized to the controls (mean \pm SEM).

\section{Statistical analysis}

All experiments were performed at least three times with different rat series or independent cultures. Student's $t$-test was used to compare two groups. The quantification of mean values and double-positive cells was analyzed with a one-way ANOVA, followed by Tukey's post hoc test for multiple comparisons. All data are expressed as the mean \pm SEM. Statistical significance was set up to $*<<0,05, * * p<0,01$, and $* * * p<0,001$. 


\section{RESULTS}

NTSR2 protein is expressed in the rat hippocampus and increases following pilocarpineinduced SE

Several lines of evidence suggest that NTSR2 mRNA is expressed in glial cells, namely astrocytes, in vitro and in vivo, including in the hippocampus (Walker et al., 1998; LépéeLorgeoux et al., 1999; Nouel et al., 1999). The NTSR2 protein was not expressed in hippocampal astrocytes (Sarret et al., 2003) but was recently described in astrocytes of the ventral tegmental area (Woodworth et al., 2018). We questioned the expression of NTSR2 protein in the hippocampus of CTL rats and its modulation in reactive astrocytes associated with epilepsy and neuroinflammation. In particular, we studied NTSR2 expression pattern and distribution in the hippocampus of rats at different stages following pilocarpine administration. Indeed, this model is characterized by rapid astrocyte and microglial activation in the hippocampus (Shapiro et al., 2008).

All rats that were injected with pilocarpine and survived developed SE (mortality rate was around $25 \%$ ). From 10 minutes to $1 \mathrm{H}$ following pilocarpine injection, rats exhibited limbic motor seizures every few minutes. After three weeks, spontaneous recurrent seizures started to appear that could last up to $60 \mathrm{sec}$; these developed into generalized seizures within the following days that persisted for the lifetime of the animals. These observations are in agreement with previous studies (Goffin et al., 2007; A. K. Sharma et al., 2007; Drislane et al., 2009; Knake et al., 2009).

We performed dual immunohistochemical labeling of NTSR2 (green) and glial fibrillary acidic protein (GFAP, red), a mature astrocyte marker (Dusart et al., 1991), at different stages following SE in pilocarpine-treated rats (Fig. 1). We chose to illustrate the results obtained at three days post SE (PILO 3D) with NTSR2 (Figs. 1 A,D) and GFAP (Figs. 1 $\mathrm{B}, \mathrm{E})$ labeling in control (CTL) (Figs. $1 \mathrm{~A}-\mathrm{C}$ ) and pilocarpine-treated rats (Figs. 1 D-F). Indeed, in our conditions, the three -day time point corresponds to strong astroglial inflammation, characterized by a dramatic increase of GFAP, in agreement with the temporal profile described by Shapiro et al. (2008). In sections from CTL rats, and at low magnification, NTSR2 immunolabeling was fairly homogeneous in all areas and layers of the hippocampus (Figs. 
$1 \mathrm{~A}, \mathrm{C})$ and showed a regional- and laminar-specific pattern within the hippocampus. Modest to moderate NTSR2 immunolabeling was found within all layers, including the stratum oriens $(0)$, stratum radiatum $(R)$ and the stratum lacunosum-moleculare (LM) of the CA1-CA2-CA3 areas, the stratum lucidum (SL) of CA2-CA3, the molecular layer (M) and the hilus $(\mathrm{H})$ of the dentate gyrus (DG) (Fig. 1A). The cell bodies of hippocampal pyramidal neurons (P) of CA1, CA2 and CA3, and granule cells (G) of DG were moderately stained. The NTSR2 immunolabeling pattern was clearly altered in PILO 3D compared to CTL rats. At low magnification, NTSR2 immunolabeling was characterized by a punctiform pattern in $\mathrm{O}, \mathrm{R}, \mathrm{LM}$ and $H$. Strong NTSR2 immunolabeling was observed within all layers and areas, including the $O, R$ and the LM of the CA1-CA2-CA3 areas, the SL of CA2-CA3, the $M$, the cell bodies of $P$ of CA1-CA2-CA3 areas, and the H of the DG (Figs. 1D,F).

\section{NTSR2 protein is expressed in astrocytes and increases following pilocarpine-induced SE}

At high magnification, all scattered GFAP positive cells located in the $\mathrm{H}$ were clearly immunolabeled for NTSR2, both in CTL and PILO 3D rats. GFAP immunolabeling was clearly enhanced in astrocytes of the DG, CA1, CA3, and the H of PILO 3D as compared to CTL rats, characteristic of astrocytic reactivity and neuroinflammation. NTSR2 was expressed in the cell bodies as well as within processes of hilar astrocytes of CTL and PILO 3D rats. While NTSR2 immunolabeling was fairly diffuse in CTL astrocytes (Figs. 1G-I, see insets), it appeared more punctiform in the astrocytes of the PILO 3D rats (Figs. 1J-L, see insets). NTSR2 staining was localized in part at the plasma membrane of astrocytes, both in CTL and PILO 3D rats, consistent with the cell membrane localization of NTSR2. In addition, NTSR2 immunolabeling of cell membranes as well as processes appeared markedly more intense in PILO 3D astrocytes compared to CTL astrocytes (compare insets in J and L with insets in G and I). All astrocytes, both in CTL and PILO 3D rats, as well as at all time points post-SE (data not shown), were NTSR2 positive.

Since differences in NTSR2 and GFAP labeling intensity in astrocytes were observed consistently between CTL and PILO 3D, we conducted semi-quantitative analysis at various time points post-SE in the DG, CA1 and CA3 to determine the relative extent of these changes (Fig. 2). In the DG, the mean NTSR2 levels were significantly increased in PILO 3D $(129,7 \pm 3,5 \%, 30 \%)$ and PILO 7D $(119,1 \pm 4,1 \%, 19 \%)$ when compared with CTL rats (100 \pm 
4,9\%; $n=3 ; p<0,01$; Tukey's test), whereas no difference was found in PILO 14D $(105,1 \pm$ $4,1 \% ; n=3 ; p>0,05 ;$ Anova). The mean NTSR2 levels were significantly decreased at three months post SE (PILO 3M) (46,7 $\pm 2,5 \%, 53 \% ; n=3 ; p<0,01$; Tukey's test) (Fig. 2A). In CA1, the mean NTSR2 levels in astrocytes were significantly increased in PILO 3D (182,3 \pm 8,7\%, 82\%; $\mathrm{n}=3 ; p<0,01$; Tukey's test), PILO 7D $(150,4 \pm 5 \%, 50 \%)$ and to a much higher extent in PILO $14 \mathrm{D}(229,2 \pm 8,9 \%, 129 \%)$ as compared to CTL (100 $\pm 4,9 \% ; n=3 ; p<0,01 ;$ Tukey's test). No difference was found in PILO $3 \mathrm{M}$ (79,3 $\pm 3,2 \%$; $n=3 ; p>0,05$; Anova) (Fig. 2B). In CA3, the mean NTSR2 levels in astrocytes were significantly increased in PILO 3D (135,9 44,1\%, 36\%), PILO 7D $(128,2 \pm 5,6 \%, 28 \%)$ and PILO 14D (123 $\pm 4,5 \%, 23 \%)$ as compared to CTL (100 \pm $4,3 \% ; n=3 ; p<0,01$; Tukey's test), whereas the mean NTSR2 levels in astrocytes were significantly decreased in PILO 3M ( $55 \pm 2,8 \%, 45 \%$; $n=3 ; p<0,01$; Tukey's test) (Fig. 2C).

NTSR2 protein is expressed in the mouse hippocampus and increases following kainateinduced SE

In order to evaluate whether increased NTSR2 expression was specific to the rat pilocarpine model of epilepsy or may occur in other models, we injected KA to adult mice, generating SE and subsequent damage to the ipsilateral CA3 subfield, along with injury to the CA1 and DG/hilar region (Mouri et al., 2008). All mice developed spontaneous recurrent seizures within 5 days, in agreement with previously published studies (Mouri et al., 2008) and displayed sustained neuroinflammation with astrogliosis from 1 day to 1 month post-KAinduced SE (M. Ding et al., 2000; Z. Chen et al., 2005).

We performed dual immunohistochemical labeling of NTSR2 (green) and microtubule-associated protein 2 (MAP2, red), a mature neuronal marker (Izant \& Mclntosh, 1980), in CTL and KA-injected mice 1 week post-SE (KA 7D), when animals displayed sustained neuroinflammation (Fig. S1). In CTL mice, and at low magnification, NTSR2 immunolabeling was fairly homogeneous in all areas and layers of the hippocampus (Figs. $\mathrm{S} 1 \mathrm{~A}, \mathrm{C}$ ) and showed a regional- and laminar-specific pattern within the hippocampus. Modest to moderate NTSR2 immunolabeling was found within all layers, including the $O, R$ and the LM of the CA1-CA2-CA3 areas, the SL of CA2-CA3, the M and the $H$ of the DG (Fig. S1A). The cell bodies of $P$ of $C A 1, C A 2$ and $C A 3$, and $G$ of DG were moderately stained. The NTSR2 
immunolabeling pattern was clearly altered in KA 7D compared to CTL mice (Fig. 1SD). At low magnification, NTSR2 immunolabeling was characterized by a punctiform and filamentous pattern in O, R, LM and H. Strong NTSR2 immunolabeling was observed within all layers and areas, including the $\mathrm{O}, \mathrm{R}$ and the LM of the CA1-CA2-CA3 areas, the SL of CA2$C A 3$, the $M$, the cell bodies of $P$ of CA1-CA2-CA3 areas, and the $H$ of the DG (Figs. S1D,F). This strong increase of NTSR2 is associated with remarkable decrease of MAP2 immunolabeling (compare Fig. S1B with Fig. S1E). At high magnification, all scattered NTSR2 positive cells located in the $\mathrm{H}$ were clearly immunolabeled for MAP2 in CTL mice. Such NTSR2 positive cells were not observed in KA 7D mice. Indeed, MAP2 immunolabeling was clearly decreased in neurons of the DG, CA1, CA2, CA3, and the H of KA 7D (Figs. 1SE,K) as compared to that of CTL mice (Figs.1SB,H). This loss of MAP2 immunolabeling may be due to the neurodegenerative processes known to occur in this model (Mouri et al., 2008). However, few scattered neurons were observed within the hippocampal lesion sites, where neuronal loss was extensive. NTSR2 was expressed in the cell bodies as well as within the proximal dendrites of hilar neurons of CTL mice and in non-neuronal, MAP2-negative cells in KA 7D mice. At high magnification, NTSR2-positive cells had an intense fibrillose appearance with strong staining in the cell bodies and processes. These NTSR2-labeled MAP2-negative cells (Figs. S1J-L) were most likely astrocytes.

We next sought to determine whether NTSR2 is also expressed and/or regulated in microglial cells, that also contribute to inflammation in pilocarpine-induced seizures in rats. To this end, we performed double immunolabeling of NTSR2 (Figs. 3 A,D, green) and the ionized macrophage and microglia specific calcium-binding adaptor molecule-1 (Iba1) (Ohsawa et al., 2004) (Figs. 3B,E, red) in CTL and pilocarpine-treated rats at different time points post-SE, in the DG, CA1 and CA3. Similar to GFAP, increased Iba1 immunolabeling, characteristic of inflammation, was observed in hippocampal microglial cells of PILO 3D rats as compared to CTL rats (Shapiro et al., 2008). High magnification images from CTL rats (Figs. 3G-I) and PILO 3D (Figs. 3J-L), clearly showed that the NTSR2 and Iba1 antibodies stained distinct cells in the $\mathrm{H}$ of the DG (Figs. 3G-L, see arrowheads), and in all other subfields of the hippocampus (data not shown), suggesting that NTSR2 is not expressed in microglial cells in vivo. Altogether, our data show that NTSR2 protein is expressed in hippocampal astrocytes 
of CTL rats and its expression is up-regulated during inflammation in pilocarpine-induced seizures.

NTSR2 protein is expressed in blood vessels and increases following pilocarpine-induced SE Immunohistochemical analysis of hippocampal slices revealed that the NTSR2 protein is expressed in blood vessels of the LM of CTL (Fig. 4B, in green) and PILO 3D rats (Fig. 4E, in green). The pattern of NTSR2 immunolabeling was clearly altered in and around the blood vessels of PILO 3D rats (Figs. 4E,F), compared to that observed in CTL rats (Fig. 4B,C). The expression of NTSR2 increased in the blood vessels of the LM of PILO 3D. Furthermore, we observed several cells in the close vicinity of these vessels (see arrows), and other cells sparsely distributed around the blood vessels (see arrowheads), which displayed also high NTSR2 immunolabeling with a punctate pattern. Because differences in NTSR2 labeling intensity in the blood vessels were observed consistently between CTL and pilocarpinetreated animals, we conducted semi-quantitative analysis in CTL and PILO 3D rats to determine the relative extent of these changes (Fig. 4G). In the LM and DG, the mean intensities of labeling for NTSR2 were significantly increased in the PILO 3D animals $(313,6 \pm$ 21,4\%, 213\%; $p<0,001$, Student's $t$-test), when compared with CTL rats (100 $\pm 12,2 \%)$. NTSR2-immunohistochemical labeling was abolished when the anti-NTSR2 antibody was omitted (data not shown). Thus, these data indicate upregulation of NTSR2 protein expression in the blood vessels during pilocarpine-induced seizures.

As for pilocarpine-treated rats, an increase of NTSR2 immunolabeling was also observed in the blood vessels of KA-treated mice (Fig. S2). Whereas in CTL mice the staining of NTSR2 around vessels was diffusively faint (Fig. S2B), in KA 7D mice NTSR2 immunoreactivity was strongly increased in the blood vessel cells of the LM compared to CTL mice (Fig. S2E). Several other cells around these vessels displayed differential, ranging from moderate to strong, NTSR2 expression, compared to CTL mice (arrowheads), while dispersed cells, likely perivascular astrocytes, projecting their processes (indicated by arrows and asterisks) were also observed around the blood vessels (Fig. S2F).

NTSR2 protein is expressed in astrocytic end-feet and endothelial cells in blood vessels following pilocarpine-induced SE 
Since all GFAP-labeled cells were also labeled for NTSR2, we performed high magnification confocal microscopic analysis to reveal the cellular compartments of astrocytes that are immunolabeled for NTSR2 (Fig. 5). We used GFAP to label astrocytes, astrocytic processes, and end-feet. Double immunofluorescence showed high NTSR2 expression in all reactive hypertrophic astrocytes (expressing high levels of GFAP) that were located around the blood vessels of the LM (Figs. 5 A-E, yellow, see arrows) in PILO 3D rats, when NTSR2 expression reached its peak. In addition, high magnification images revealed that astrocytic processes as well as their end feet that project on blood vessels were also strongly immunolabeled for NTSR2 (Figs. 5F-I, yellow, see arrowheads). Nevertheless, other cells that constitute the blood vessels that were not GFAP-positive also expressed high levels of NTSR2 (see stars in Figs. 5F-I). These vessels are constituted by specialized endothelial cells, surrounded by a basal lamina, pericytes, astrocyte-end feet that collectively form the blood-brain barrier (BBB), microglia and neurons (ElAli et al., 2014; Uzunalli et al., 2019).

In order to determine the identity of the NTSR2-expressing cells in blood vessels, we used antibodies directed against endothelial and pericyte markers, namely the endothelial cell adhesion molecule, CD31, and the platelet derived growth factor receptor-beta, PDGFRß, respectively (Uzunalli et al., 2019). The basal lamina was revealed using an antibody against Collagen IV (ColIV), which is the most abundant extracellular matrix protein in the endothelial basement membrane (Figs. 6-7).

We first examined whether endothelial cells expressed NTSR2. To this end, we performed NTSR2, CD31 and CollV triple immunolabeling in PILO 3D rats (Figs 6A-H). High magnification images of LM blood vessels revealed that NTSR2 was expressed in endothelial cells since both NTSR2 and CD31 stained the same cells (Figs. 6I,J). Endothelial cells displayed a punctiform NTSR2 immunolabeling pattern. Note that the CollV immunolabeling (Fig. 6L, see arrowheads) was closely apposed to CD31 labeling (Fig. 6L, see arrows), as endothelial cells were surrounded by basal lamina. Finally, we sought to determine whether NTSR2 was expressed in blood vessel pericytes, which are present on the abluminal surface of the endothelium and in direct contact with endothelial cells while separated by the basement membrane (Armulik et al., 2011). NTSR2, CD31 and PDGFR 3 triple immunolabeling was carried out in PILO 3D rats (Fig. 7). High magnification images showed that NTSR2 was faintly 
expressed in PDGFRß-labeled pericytes, as compared with strong labeling of CD31-labeled endothelial cells (Figs 7I-L). The faint NTSR2 immunolabeling displayed by pericytes is more diffuse than that showed for astrocytes and endothelial cells. Thus, these results indicated that NTSR2 was expressed by several cellular components of the blood vessels.

Taken together, our data suggest that the increased NTSR2 expression in astrocytes and blood vessels in PILO rats is associated with neuroinflammation, since increased GFAPlabeled astrocytes were observed in the pilocarpine model. Finally, Iba1-labeled microglial cells around the blood vessels did not express NTSR2, similar to all other hippocampal areas (data not shown).

\section{Inflammation modulates differentially the expression of neurotensin receptors in glial primary cultures}

Before investigating whether neuroinflammation can regulate NTSR2 expression, we first performed NTSR2 (Fig. 8B, green) and GFAP (Fig. 8C, red) double immunofluorescence labeling on primary glial cultures to validate our findings regarding NTSR2 astrocytic expression in rat brain tissue. Confocal microscopy analysis confirmed that all GFAP-labeled astrocytes were co-labeled for NTSR2 within the cytoplasm as well as at the cell membrane and processes (Figs. 8B,D, see arrowheads). The strong NTSR2 immunostaining observed in the cell body likely corresponds to the Golgi apparatus. We observed that not only astrocytes but also all cells in these glial cultures, that include astrocytes and microglial cells, were NTSR2-labeled. We performed NTSR2 (Fig. 8F, green) and Iba1 (Fig. 8G, red) double immunofluorescence on the same cultures and we report here for the first time that NTSR2 was expressed in microglial cells from primary glial cultures, in contrast to our in vivo findings. NTSR2 immunolabeling was more intense within the cell body and membrane compared to the cell processes (Figs. 8F,H). Surprisingly, we observed that expression of NTSR2 in microglia was stronger than that observed in astrocytes of CTL glial cultures. Indeed, quantitative analysis showed that the average fluorescence intensity for NTSR2 was significantly higher in Iba1-labeled microglia (149,4 $\pm 19,7 \%, 49 \% ; p<0,05$, Student's $t$-test), compared with that of GFAP-labeled astrocytes (100 $\pm 13 \%)$. 
In order to study the effects of inflammation on the regulation of NTSR2 expression in primary glial cultures, cells were treated with different proinflammatory factors, including IL1 $\beta$ and LPS. The inflammatory response of these cells to IL1 $\beta$ or LPS was monitored by following the expression of IL1 $\beta$ and MCP-1/ccl2 mRNA by RT-qPCR at different time points $(1,6$ and $24 \mathrm{H})$, and synthesis of MCP-1/CCL2 by Elisa after $24 \mathrm{H}$ treatment. Quantitative analysis showed that IL1 $\beta$ did not affect the levels of IL1 $\beta$ mRNA at all time points analyzed (IL1 $\beta$ 1H: $1,4 \pm 1,3$; IL1 $\beta 6 \mathrm{H}: 3,2 \pm 0,6$; IL1 $\beta 24 \mathrm{H}: 3,3 \pm 1,2$ ) when compared to CTL levels (1 \pm 0,$0 ; n=8 ; p>0,05$; Anova), whereas LPS significantly induced IL1 $\beta$ mRNA levels at $1 \mathrm{H}(8,6 \pm$ $2,5)$ and $6 \mathrm{H}(11,5 \pm 2,3)$. However, the levels of IL1 $\beta$ mRNA at $24 \mathrm{H}(3,6 \pm 1,2)$ were not significantly different from CTL levels ( $1 \pm 0,0 ; n=8 ; p>0,05$; Anova) (Fig. 9A). The expression of MCP-1/ccl2 mRNA levels was significantly induced by IL1 $\beta$ as well as by LPS at $6 \mathrm{H}$ (IL1 $\beta 6 \mathrm{H}$ : $4,1 \pm 1 ; n=8 ; p<0.05 ;$ LPS $6 \mathrm{H}: 8,2 \pm 1 ; \mathrm{n}=8 ; p<0,001$, Tukey's test) (Fig. 9B). However, no significant modulation of MCP-1/Ccl2 mRNA was observed after either IL1 $\beta$ or LPS treatment at $1 \mathrm{H}$ (IL1 $\beta$ 1H: 1,6 $\pm 0,5 ; \mathrm{n}=8$; Anova; LPS $1 \mathrm{H}: 1,1 \pm 0,2 ; \mathrm{n}=8 ; p>0,05 ;$ Anova) and $24 \mathrm{H}$ (IL1 $\beta$ 24H: $2,4 \pm 1 ; n=8 ; p>0,05$; Anova; LPS $24 \mathrm{H}: 2,8 \pm 0,8 ; \mathrm{n}=8 ; p>0,05$; Anova) (Fig. 9B). Consistent with the RT-qPCR data, MCP-1/CCl2 is produced at significant levels in the supernatants of cultured glial cells after $24 \mathrm{H}$ treatment by IL1 $\beta(357,9 \pm 25,4 \mathrm{ng} / \mathrm{ml} ; 545,5 \%)$ or LPS $(716 \pm 27,4 \mathrm{ng} / \mathrm{ml} ; 1091,3 \%)$ as compared to CTL $(65,6 \pm 14,1 \mathrm{ng} / \mathrm{ml}, 100 \%$; $\mathrm{n}=8$; $p<0,01$; Tukey's test) (Fig. 9C). These data confirmed that our glial cultures were inflamed.

We next analyzed the expression of NTSR2 and the other receptors, NTSR1 and NTSR3, after 1, 6 and $24 \mathrm{H}$ treatment with either IL1 $\beta$ or LPS. Inflammation induced rapid upregulation of mRNAs encoding NTSR2 (IL1 $\beta$ 1H: 2,9 $\pm 0,7 ; n=8 ; p<0,05 ;$ Tukey's test; LPS $1 \mathrm{H}: 3,4 \pm 0,9 ; \mathrm{n}=8 ; p<0,01$; Tukey's test) (Fig 9D) and to a lower extent NTSR3 (IL1 $\beta$ 1H: 1,4 \pm 0,2; $\mathrm{n}=8 ; p<0,05$; Tukey's test; LPS $1 \mathrm{H}: 1,60 \pm 0,2 ; \mathrm{n}=8 ; p<0,001$; Tukey's test) (Figs 9D,E) at $1 \mathrm{H}$ after IL1 $\beta$ or LPS treatments, whereas no significant modulation of NTSR2 (IL1 $\beta 6 \mathrm{H}: 1,4 \pm$ 0,$5 ; \mathrm{n}=8 ; p>0,05$; Anova; LPS 6H: 2,1 $\pm 0,4 ; \mathrm{n}=8 ; p>0,05$; Anova) and NTSR3 (IL1 $6 \mathrm{H}: 1 \pm 0,1$; $p>0,05$; Anova; LPS $6 \mathrm{H}: 0,8 \pm 0,1 ; n=8 ; p>0,05$; Anova) mRNA was observed after either IL1 $\beta$ or LPS treatment at $6 \mathrm{H}$ (Figs. 9D,E). However, significant decrease of mRNA encoding NTSR3 was observed at $24 \mathrm{H}$ after IL1 $\beta$ or LPS treatments (IL1 $24 \mathrm{H}: 0,6 \pm 0,1 ; n=8 ; p<0,05$; Tukey's test; LPS 24H: 0,5 $\pm 0,1 ; n=8 ; p<0,01 ;$ Tukey's test) (Fig 9E). Our study showed no significant 
modulation of NTSR1 encoding mRNA at all time points examined (IL1 $\beta$ 1H: $2 \pm 0,7 ;$ IL1 $\beta 6 \mathrm{H}$ : $1,7 \pm 0,3$; IL1 $24 \mathrm{H}: 1,5 \pm 0,8$; LPS $1 \mathrm{H}: 3,1 \pm 0,8$; LPS $6 \mathrm{H}: 1,8 \pm 0,4 ;$ LPS $24 \mathrm{H}: 0,6 \pm 0,2 ; n=8$; $p>0,05$; Anova) (Fig. 9F). These results indicate that inflammation differently affects the expression of neurotensin receptors in primary glial cultures.

\section{NTSR2 is expressed as an immediate early gene following inflammatory stimuli in glial primary cultures.}

The transient and rapid (as early as $1 \mathrm{H}$ ) upregulation by inflammation of mRNAs encoding NTSR2 and NTSR3 was reminiscent of the pattern of expression of immediate-early genes (IEGs), also referred to as primary response genes (Herschman, 1991; Lau \& Nathans, 1991). IEGs are also characterized by the fact that the transient and rapid response to stimuli does not require protein synthesis, and that their expression is usually induced by agents that block protein synthesis (Mehendale \& Apte, 2009). In order to determine whether the activation of NTSR2 and NTSR3 requires protein synthesis, we incubated glial cells with or without LPS $(1 \mu \mathrm{g} / \mathrm{ml})$ and/or cycloheximide $(\mathrm{CHX})$, a protein synthesis inhibitor (Alberini, 2008), at a classical dose of $10 \mu \mathrm{g} / \mathrm{ml}$ (Cochran et al., 1984; Greenfield et al., 1996), for 1, 6 and $24 \mathrm{H}$ prior to RNA extraction and RT-qPCR analysis. We used as a standard positive control Zif-268/egr-1, a zinc-finger protein known to be rapidly induced in diverse cell types following activation by a variety of stimulants, including mitogens, cell differentiating agents, and LPS (Gashler \& Sukhatme, 1995; Yao et al., 1997; Xu et al., 2001). We first evaluated whether Zif-268/egr-1 behaved as an IEG in primary rat glial cells. RT-qPCR analysis demonstrates that in these cells, LPS alone induced strong, rapid and transient expression of Zif-268 mRNA, with a peak in mRNA levels occurring at the $1 \mathrm{H}$ time point $(23 \pm 0,5 ; 23$-fold; $\mathrm{n}=3$; $p<0,001$; Tukey's test) as compared to untreated CTL cells $(1 \pm 0,0)$ (Fig.10A). Zif-268 mRNA expression levels returned back to baseline at the 6 and $24 \mathrm{H}$ time points (Fig. $10 \mathrm{~A}$, left plot), consistent with the temporal profile of zif-268 gene induction described previously (Hughes et al., 1993; Yamaji et al., 1994). CHX alone resulted in a more potent induction of Zif-268/egr-1 mRNA at all time points compared to CTL and LPS (Fig. 10, right plot) with a 60fold induction at $1 \mathrm{H}(59,9 \pm 2 ; n=3 ; p<0,01$; Tukey's test) compared to CTL (Fig. 10A, right diagram) while $\mathrm{CHX}$ alone resulted in a 2,6-fold induction at $1 \mathrm{H}(59,9 \pm 2 ; n=3 ; p<0,01$; Tukey's test) when compared to LPS $1 \mathrm{H}(23 \pm 0,5)$. When combining LPS with $\mathrm{CHX}$ in glial cell 
cultures, we observed a super-induction of Zif-268/egr-1 mRNA at all time points compared to LPS (Fig. 10A, left plot) with a 7,7-fold super-induction of Zif-268/egr-1 mRNA levels at 1H $(177,1 \pm 15,3 ; n=3 ; p<0,05$; Tukey's t-test) over LPS alone (Fig. 10A, right diagram). This LPSCHX super-induction was most obvious when the Zif-268/egr-1 mRNA levels returned back to CTL levels following LPS treatment (Fig. 10A, left plot). These data suggest that in rat primary glial cells, inhibition of translation prevents the synthesis of a protein/or proteins that negatively regulate Zif-268/erg-1 expression. Thus, the zif-268 gene is induced by LPS in rat primary glial cells and this induction is independent of de novo protein synthesis. These results show that Zif-268 is induced as an IEG in primary glial cultures activated by LPS, consistent with other cell types (Hughes et al., 1993; Yamaji et al., 1994; Gashler et al., 1995; Yao et al., 1997; Xu et al., 2001).

As shown in Figure 9D,E, LPS alone also induced rapid and transient expression of NTSR2 and NTSR3 (Figs. 10B,C, left plots), with mRNA expression peaking at the $1 \mathrm{H}$ time point (NTSR2: $3,7 \pm 0,3$; NTSR3: $2,8 \pm 0,2 ; n=3 ; p<0,001$; Tukey's test) when compared to untreated CTL glial cells $(1 \pm 0,0)$ (Figs. 10B,C, right diagrams). LPS induction of NTSR2 (3,7fold) and NTSR3 (2,8-fold) mRNA levels was less potent than that of Zif-268 (23-fold), and decreased less rapidly (Figs. 10B,C, left plots). CHX-treatment alone also induced NTSR2 (3,9 $\pm 0,3 ; 6 \mathrm{H}: 3 \pm 0,2 ; 3$-fold; $24 \mathrm{H}: 3,4 \pm 0,2 ; 3,4$-fold; $\mathrm{n}=3 ; p<0,001$; Tukey's t-test) and NTSR3 (1H: 3,1 \pm 0,2; 3,1-fold; $6 \mathrm{H}: 2,2 \pm 0,1 ; 2,2$-fold; $24 \mathrm{H}: 2,1 \pm 0,0 ; 2,1$-fold; $\mathrm{n}=3 ; p<0,001$; Tukey's test) mRNA levels at all time points compared to CTL (Figs. 10A-C), but to a lesser extent than the Zif-268/erg-1 induction by $\mathrm{CHX}$ (from 60-fold induction at $1 \mathrm{H}$ to 91,8 -fold at $24 \mathrm{H}$ ) (Fig. 10 A). In contrast to Zif-268/erg-1, NTSR2 and NTSR3 did not show any significant superinduction response at all time points examined when $\mathrm{CHX}$ treatment was combined with LPS or $\mathrm{CHX}$ treatment alone (Figs. 10B,C, left plots and right diagrams). Thus, although $\mathrm{CHX}$ induced expression of NTSR2 and NTSR3 in glial cells, there was no additional stimulation of these genes by LPS treatment (Figs. 10B,C, left plots). CHX treatment did not block activation of NTSR2 and NTSR3, similarly to what was described for c-fos (Yamaji et al., 1994) and BDNF (Hughes et al., 1993). Our results show that upon stimulation with a proinflammatory factor such as LPS, induction of NTSR2 and NTSR3 mRNA levels were not dependent upon de novo protein synthesis. Taken together with the rapid and transient kinetics of activation, they suggest that NTSR2 and NTSR3 are new IEGs in rat glial cells. 


\section{The vectorized NT analog VH-N412 regulates NTSR2, GFAP and Iba1 protein expression in primary glial cultures}

We developed VH-N412 is a vectorized version of a NT functional fragment. It encompasses the C-terminal NT part (8-13, RRPYIL-OH), the shortest NT fragment with full binding and pharmacological activities (Granier et al., 1982) conjugated via a PEG6 linker to VH4129, a cyclic peptide ( [CMPipRLRSarC]c) encompassing non-natural amino-acids, that binds to the low-density lipoprotein receptor (LDLR) and that we previously described (Jacquot et al., 2016). VH4129 belongs to a family of cyclic peptides that can be conjugated to a variety of cargos including fluorophores, peptides and proteins to promote transcytosis across the BBB and enhance their cellular uptake and brain delivery that we previously described (Malcor et al., 2012; Jacquot et al., 2016; Molino et al., 2017; David et al., 2018), and that others have used to functionalize nanoparticles and liposomes to increase brain delivery of anticancer drugs (Zhang et al., 2013; Chen et al., 2017; Shen et al., 2018). VHN412 undergoes transcytosis across the BBB and induces rapid hypothermia when administered i.v. to rats or mice, and we have shown that it elicits neuroprotective and antiinflammatory effects following in vivo administration in KA-induced TLE in mice and neuroprotection in vitro (Soussi et al., manuscript in preparation). Since NTSR2 mRNA expression is regulated by inflammation, we investigated whether its vectorized ligand $\mathrm{VH}-$ N412 could in turn modulate NTSR2 protein expression in primary inflamed glial cultures. To this end, dual NTSR2 (green) and GFAP (red) immunocytochemistry (Fig. 11) was carried out on primary glial cultures treated with $1 \mu \mathrm{M}$ VH-N412 (Figs. 11b,h,n), $10 \mathrm{ng} / \mathrm{ml}$ IL1 $\beta$ (Figs. 11c,i,o), $10 \mathrm{ng} / \mathrm{ml}$ IL1 $\beta+1 \mu \mathrm{M}$ VH-N412 (Figs. 11d,j,p), $10 \mu \mathrm{g} / \mathrm{ml}$ LPS (Figs. 11e,k,q) or 10 $\mu \mathrm{g} / \mathrm{ml}$ LPS $+1 \mu \mathrm{M}$ VH-N412 (Figs. 11f,l,r) for $24 \mathrm{H}$, and compared to untreated glial cells (Figs $11 \mathrm{a}, \mathrm{g}, \mathrm{m})$. The dose of $1 \mu \mathrm{M}$ was chosen based on neuroprotection effects obtained at this dose compared to $0,1,1$, and $10 \mu \mathrm{M}$ (Soussi et al., manuscript in preparation). Quantitative analysis showed that $1 \mu \mathrm{M}$ VH-N412 alone did not modulate NTSR2 protein expression $(93,7$ $\pm 13,7 ; n=3 ; p>0,05 ;$ Anova), as compared to untreated CTL astrocytes (100 \pm 13 ) (Fig. 11B). IL1 $\beta$ caused significant increase of NTSR2 protein expression $(199,1 \pm 38,5 ; 99 \% ; n=3$; $\mathrm{p}<0,05$; Tukey's test) compared to CTL, which was significantly down-regulated upon $\mathrm{VH}-$ N412 treatment (IL1 $\beta+$ VH-N412: 66,4 $\pm 9,3 ; 133 \% ; n=3 ; p<0,01 ;$ Tukey's test). LPS alone or 
together with VH-N412 did not modulate NTSR2 protein expression (LPS: $150 \pm 29,6$; LPS + VH-N412: 91,8 \pm 14,7; $n=3 ; p>0,05 ;$ Anova) (Fig. 11B). In contrast to NTSR2, VH-N412 alone significantly reduced GFAP protein expression ( $51 \pm 3,6 ; n=3 ; p<0,05$; Tukey's test) compared to untreated CTL cultures (100 \pm 13 ) (Fig. 11C), suggesting that VH-N412 reduced astrocytic inflammation. IL1 $\beta$ alone (102 $\pm 10 ; n=3 ; p>0,05 ;$ Anova) and IL1 $\beta+V H-N 412(110,9 \pm 16,4$; $\mathrm{n}=3 ; \mathrm{p}>0,05$; Anova) had no significant effect on GFAP protein levels compared to untreated CTL astrocytes (Fig. 11C). GFAP levels were not modulated by LPS $(132,8 \pm 13,8 ; n=3 ; p>0,05$; Anova) when compared to CTL untreated astrocytes (Fig 11C). However, VH-N412 significantly reduced GFAP expression in the LPS-treated astrocytes (LPS + VH-N412: 75,7 \pm 6,$1 ; 57 \% ; n=3 ; p<0,01$; Tukey's test) (Fig 11C). Altogether, our data indicate that VH-412 may regulate astrocytic inflammation.

Considering that NTSR2 is expressed also in microglial cells in vitro, NTSR2 and Iba1 immunocytochemistry (Fig. 12) was carried out on the same glial cultures treated under the same conditions: $1 \mu \mathrm{M}$ VH-N412 (Figs. 12b,h,n), $10 \mathrm{ng} / \mathrm{ml}$ IL1 $\beta$ (Figs. 11c,i,o), $10 \mathrm{ng} / \mathrm{ml}$ IL1 $\beta$ + $1 \mu \mathrm{M}$ VH-N412 (Figs. 12d, j, p), $10 \mu \mathrm{g} / \mathrm{ml}$ LPS (Figs. 12e, k, q) or $10 \mu \mathrm{g} / \mathrm{ml}$ LPS $+1 \mu \mathrm{M}$ VHN412 (Figs. 12f, I , r) for $24 \mathrm{H}$. Treated microglia were compared to untreated microglia (Figs $12 \mathrm{a}, \mathrm{g}, \mathrm{m})$ and the levels of NTSR2 and Iba1 were quantified. As for astrocytes, VH-N412 alone did not regulate NTSR2 protein expression (102,1 $\pm 7,9 ; \mathrm{n}=3 ; p>0,05$; Anova) in microglial cells, as compared to CTL untreated microglia $(100 \pm 13,2)$ (Fig. 12B). IL1 $\beta$ tended to increase NTSR2 protein levels but did not reach the level of significance $(105,5 \pm 12 ; n=3 ; p>0,05$; Anova), as compared to those of CTL. On the other hand, LPS led to significant increased NTSR2 protein expression (189,7 $\pm 26,2 ; 90 \% ; n=3 ; p<0,01$; Tukey's test). Treatment of the cultures with VH-N412 simultaneously with IL1 $\beta$ or LPS led to significantly decreased NTSR2 levels compared to treatment, either with IL1 $\beta$ or LPS alone (IL1 $\beta+$ VH-N412: 47,1 $\pm 7,8$; 104\%; LPS + VH-N412: 63,3 $\pm 4,4 ; 127 \% ; n=3 ; p<0,01 ;$ Tukey's test) (Fig. 12B). VH-N412 treatment in our non-inflamed primary glial cultures did not result in changes of Iba1 protein expression (78,1 $\pm 6,8 ; n=3 ; p>0,05$; Anova), as compared to CTL $(100 \pm 9,6)$ (Fig. 12C). However, Iba1 protein expression was significantly increased after $24 \mathrm{H}$ treatment with either IL1 $\beta(183,7 \pm 16 ; 84 \% ; n=3 ; p<0,05 ;$ Tukey's test) or LPS $(266,7 \pm 35,2 ; 167 \% ; n=3$; $p<0,01$; Tukey's test). Finally, VH-N412 significantly decreased Iba1 protein expression both in the IL1 $\beta(53,9 \pm 6,6 ; 130 \% ; n=3 ; p<0,01 ;$ Tukey's test) and in the LPS-treated microglia 
$(109,9 \pm 8,6 ; 157 \% ; n=3 ; p<0,01 ;$ Tukey's test), suggesting its potential role in modulating microglial inflammation. Collectively, these results show that NTSR2 is induced at high levels in reactive astrocytes and microglia during pathology, and that astrocyte and microglial reactivity can be modulated by NT analogues. 


\section{DISCUSSION}

Our study shows that NTSR2 protein is expressed in astrocytes of the adult rodent hippocampus and its expression is increased together with astrocyte reactivity in the hippocampus at the early phases following induction of SE, from 3 to 14 days, and decreased at 3 months post-SE. All the GFAP positive cells co-expressed NTSR2. Following SE, NTSR2 immunoreactivity was also increased in perivascular astrocytes and their end-feet and was apparent in endothelial cells. Proinflammatory factors such as IL-1 $\beta$ and LPS induced NTSR2 in astrocytes, but also in microglia in vitro. Astrocytic NTSR2 expression showed characteristic immediate early gene response under inflammatory conditions. Treating cultured glial cells with a vectorized NT analogue decreased NTSR2, GFAP and Iba1 expression, suggesting a role for NTSR2 in the downregulation of astroglial neuroinflammation by NT.

\section{NTSR2 protein is expressed in astrocytes in rat brain}

In the present work, we investigated in vivo and in vitro, by immuno-histo- and immuno-cytochemistry laser scanning confocal microscopy approaches, the expression of the NTSR2 protein in rat hippocampal cells using GFAP labeling combined with a specific and validated anti-NTSR2 antibody. Our study clearly demonstrates for the first time that the NTSR2 protein is expressed in the DG and CA1-CA3 regions of Ammon's horn.

Recently, NTSR2 was shown to be expressed in the DG and CA3 in a transgenic mice line ( $\mathrm{NtSR} 2^{\mathrm{Cre} /+, \mathrm{GFP}}$ ), however the identity of the non-neuronal (NeuN-negative) NTSR2expressing cells was not revealed (Manning et al., 2019). In our study, we observed differential NTSR2 expression in hippocampal neurons (Kyriatzis et al., in preparation) but in the present report we chose to focus our attention on the non-neuronal expression of the NTSR2 protein, in particular in astrocytes. We show for the first time NTSR2 protein expression in all GFAP-labeled astrocytes. A high throughput study showed that NTSR2 mRNA is one of the most abundant receptor-encoding mRNAs in purified mice astrocytes (Y. Zhang et al., 2014), and in vitro, NTSR2 has been used as an astrocytic marker in single-cell transcriptomic analysis (Dulken et al., 2017). RT-qPCR assays showed that cultured astroglial cells express NTSR2 mRNA and its vNTSR2 isoform rather than NTSR1 (Ayala-Sarmiento et 
al., 2015). In situ hybridization studies in vivo showed NTSR2 mRNA expression in rat astrocytes (Walker et al., 1998; Yamauchi et al., 2007), and in mouse astrocytes of P17 mice (Cahoy et al., 2008). Dual immunohistochemical labeling of GFAP and in situ hybridization of NTSR2 mRNA suggested that NTSR2 was expressed only a small subset of astrocytes in the rat brain (Nouel et al., 1999). More recently, in situ hybridization localized NTSR2 mRNA in a subpopulation of astrocytes of the median preoptic nucleus (Tabarean, 2020). At the protein level, previous studies based on NT-binding experiments and sensitivity to levocabastine, a selective non-peptide histamine $\mathrm{H} 1$ receptor antagonist and NTSR2 ligand that does not bind to NTSR1 nor NTSR3 (Sarret \& Beaudet, 2002), suggested NTSR2 protein expression in cultured astrocytes; bound fluorescent NT indicated that receptor expression concerned only a sub-population of astrocytes in culture. More recently, NTSR2 immunostaining was reported in astrocytes of the ventral tegmental area (Woodworth et al., 2018). However, other studies based on double-immunolabeling combining an N-terminal-specific anti-NTSR2 antibody and the astrocyte marker calcium-binding protein $\mathrm{S} 100 \beta$, reported absence of NTSR2 immunostaining in adult rat brain astrocytes (Sarret et al., 2003).

With regard to subcellular localization, we observed in vivo but even more clearly in vitro, that NTSR2 is localized at the cell membrane, typical for a receptor; however we also observed NTSR2 aggregates in astrocytic processes and cell bodies, reminiscent of NTSR2 localization in intracellular vesicles and in the trans-Golgi network described in rat spinal cord neurons (Perron et al., 2006).

\section{NTSR2 is induced in reactive astrocytes in rodent models of epilepsy}

We questioned whether astrocytic NTSR2 expression was modulated in pathological situations involving astrocyte reactivity. To address this issue, we studied two pathophysiological models of TLE induced by pilocarpine in rats and KA in mice. NTSR2 expression was largely increased both after pilocarpine- and KA-induced SE in all hippocampal areas. The NTSR2 increase following SE coincides with the peak of astrocyte activation and prolonged elevation of astrocytic $\mathrm{Ca}^{2+}$ signaling, which occurs at 3 days postSE in different rodent experimental models (Seifert et al., 2010). These reactive astrocytes were shown to contribute to delayed neuronal death of cortical and hippocampal pyramidal cells following pilocarpine-induced SE (Ding et al., 2007). Accordingly, at 3 months post-SE, 
characterized by spontaneous recurrent seizures and attenuated astrocytic reactivity (Garzillo and Mello, 2002; Choi and Koh, 2008), we observed concomitant decrease of NTSR2. The fact that the NTSR2 expression pattern closely follows that of astrocyte reactivity during the course of the disease, provides a hint that this receptor is involved in the neuroinflammation processes associated with pathology. Despite well-established commonalities, astrocyte reactive gliosis can be heterogeneous in response to specific injury. For instance, the molecular phenotypes of reactive astrocytes induced by ischemia and LPS suggest that they may be beneficial or detrimental, respectively (Zamanian et al., 2012). In other neuroinflammatory settings, such as those induced by brain stab-wound in rats, a marked increase in the number of NTSR2 mRNA expressing astrocytes around the lesion has been described, associated with increased NTSR2 mRNA expression at the cellular level (Nouel et al., 1999). Taken with our data, these results suggest that NTSR2 upregulation during astrocytic reaction may be common to different brain injuries. Although we did not observe NTSR2 labeling in CTL mouse MAP2-negative cells resembling astrocytes, our immunohistochemical analysis of mice brain after KA injection also showed enhanced expression of NTSR2 protein following acute neuronal injury. The fibrillose appearance of the labeled cells and absence of co-labeling with the mature neuronal marker MAP2 suggest they are astrocytes. Thus, NTSR2 upregulation in astrocytes seems to be common to different species and to different pathophysiological conditions inducing TLE.

\section{NTSR2 is induced in reactive astrocytes and microglial cells in vitro following proinflammatory stimulation}

A major finding of our study is that inflammation mediated by proinflammatory factors IL1 $\beta$ and LPS significantly enhanced both NTSR2 mRNA and protein levels in astroglial cells, congruent to our in vivo data. This is the first demonstration of NTSR2 mRNA and protein up-regulation following IL1 $\beta$-mediated inflammation and results are in agreement with Pang et al. (2001), who reported increased expression of NTSR2 mRNA in purified astrocytes following LPS stimulation. In the adult rat hippocampus, we showed that NTSR2 was expressed specifically in astrocytes and not in CTL or reactive microglia, that also contribute to inflammation associated with epilepsy. In the pilocarpine model, we observed strong Iba1 immunolabeling, indicative of microglial reactivity. However, we found no NTSR2 staining in Iba1-positive cells in vivo, despite the fact that we observed strong NTSR2 
expression in microglial cells in vitro. This discrepancy could result from insufficient microglia activation in the pilocarpine model of epilepsy, raising the question whether in another pathological model, appropriate proinflammatory factors could induce NTSR2 expression in activated microglia. Alternative hypotheses include differential behavior of microglial cells in in vivo and in vitro conditions, and/or distinct microglia responses to the proinflammatory factors expressed in vivo and those we assessed in vitro. To our knowledge, this is the first demonstration of NTSR2 expression in microglia, as previous studies reported that murine and human microglia cells express only NTSR3 but not NTSR1 nor NTSR2 (Martin et al., 2003; Patel et al., 2016).

\section{VH-N412 decreases astrocyte and microglial reactivity}

In vitro, the vectorized NT analog VH-N412 led to decreased NTSR2, as well as GFAP and Iba1 expression upon inflammatory conditions, suggesting that binding of VH-N412 on NTSR2 attenuates astrocytic and microglia reactivity during inflammation. It has been shown that activation of NTSR2 by its ligand can result in modulation of gene expression (Vita et al., 1998; Gendron et al., 2004; Ayala-Sarmiento et al., 2015). Inhibition of NTSR2 by JMV449, a general NTSR antagonist, suppressed GFAP expression, potentially by affecting transcriptional 3 (STAT3) factor signaling (Ando et al., 2019). Also, NT and NT agonist JMV449, significantly induced the proliferation rate of some astrocytic tumor cell lines, suggesting that NT is secreted by astrocytes and acts as an autocrine and/or paracrine growth factor (Camby et al., 1996). In our experimental settings we do not know whether VH-N412 activates or inhibits NTSR2 considering that different NTSR2 ligands such as NT, SR48692 (a selective non-peptide NTSR1 antagonist) and levocabastine, behave as agonists or antagonists, depending on specific signaling events and cell types studied (Vita et al., 1998; Dobner, 2005). Nevertheless, one may hypothesize that NTSR2 up-regulation during inflammation allows NT or its analogs to antagonize inflammatory processes and that NTSR2 could be a relevant pharmacological target in the modulation of neuroinflammation.

G protein coupled receptors (GPCRs) have been shown to play important roles in inflammation, and their involvement in transmembrane signaling is primarily responsible for the mediation of complex inflammatory (and anti-inflammatory) responses (reviewed in Sun and Ye, 2012). As such, the NT receptors and the neurotensinergic system have been 
involved in various inflammatory disease states. NT has been shown to promote an acute inflammatory response in an experimental model of colon inflammation (Castagliuolo et al., 1999). In contrast, an ameliorative effect of NT in the colitis model of inflammatory bowel disease has been reported, that reduces the levels of the proinflammatory cytokines IL-6 and tumor necrosis factor- $\alpha$ (TNF- $\alpha$ ) that are highly expressed in this model (Akcan et al., 2008). Recently, NT exhibited anti-inflammatory activity in induced asthma, and this beneficial effect was mediated through NTSR1 (Russjan \& Kaczyńska, 2019). With regard to brain diseases, NT has been studied in Schizophrenia, Alzheimer's disease, and Parkinson's disease among others (reviewed in St-Gelais et al., 2006). However, the specific role of NT in neuroinflammation in these disorders has not been addressed, nor which receptors are involved. A large and mild decrease of NTSR2 and NT mRNA respectively has been described in the temporal lobe of Alzheimer's disease patients (Gahete et al., 2010).

\section{NTSR2 is expressed in blood vessel endothelial cells and increased in rodent models of epilepsy}

Besides NTSR2 expression in astrocytes of the hippocampal parenchyma, we observed perivascular NTSR2 labeling that was significantly enhanced (an average of 3-fold increase) in the PILO rats in the hours and days that follow SE as exemplified at 3 days postSE. Detailed studies addressing differences between parenchymal and perivascular astrocytes are lacking, and, although they are bound to have distinct functions, both showed increased GFAP and NTSR2 in the PILO rats. Confocal analysis of GFAP and NTSR2 double labeling immunohistochemistry showed some NTSR2 and GFAP co-localization in astrocytic end-feet in the PILO rats, that are polarized around the basement membrane to maintain the structural integrity of the BBB and restrict vascular permeability (Abbott et al., 2006). In addition, the area that surrounds the blood vessels in PILO rats contained a large number of reactive hypertrophic astrocytes known to be associated with neurologic disease, including inflammation and neurodegeneration (Hol \& Pekny, 2015).

A number of molecules have been identified whose expression is increased in reactive astrocytes as well as in their perivascular processes. For instance, aquaporin-4 (AQP-4) that mediates the delivery of nutrients to surrounding neurons is increased in sclerotic hippocampi from patients with temporal lobe epilepsy and correlates positively 
with increased GFAP in the astrocyte plasma membranes, but also in perivascular end-feet (Lee et al., 2004).

One major finding of our study is that NTSR2 is not exclusively co-localized with GFAP but is also found distributed between astrocytic end-feet and blood vessel lumen. Triple immunolabeling experiments to localize NTSR2, together with the CD31, PDGFR $\beta$ and Collagen IV markers that specifically label endothelial cells, pericytes and basal lamina respectively, led to the finding that in addition to reactive perivascular astrocytes and their end-feet, NTSR2 is expressed in brain endothelial cells, and only faintly in pericytes in the PILO-treated rats. Co-upregulation of specific proteins in both astrocytes and endothelial cells in disease or inflammation has been reported. For instance, IL1 $\beta$ up-regulates GLUT1 both in astrocytes and endothelial cells (Jurcovicova, 2014). Similarly, Lcn2, a secreted lipophilic protein was strongly induced after LPS injury, not only in astrocyte reactive gliosis but also in endothelial cells (Zamanian et al., 2012). Taken together, our results indicate that NTSR2 is expressed by different components of the blood vessels, in particular perivascular astrocytes and endothelial cells in PILO rats and may be implicated in the structural integrity of the BBB. While human pulmonary artery endothelial cells (PAECS) were shown to express NTSR3 (Shults et al., 2018), to our knowledge, our study is the first to show NTSR2 expression in blood vessels in general and in the BBB in particular. This finding suggests that while NTSR2 induction is associated with neuroinflammation involving parenchymal and perivascular astrocyte reactivity, NTSR2 may also play a specific role in brain endothelial cells. For instance, NTSR2 could be involved in modulating endothelial cell properties due to its function as a signal transduction receptor. Indeed, different studies report that NT stimulation of NTSRs activates the extracellular signal regulated kinases $1 / 2$ (ERK1/2) ( Martin et al., 2003; Navarro et al., 2006; Sarret et al., 2002). Interestingly, it has been shown that NTSR2 is internalized after NT binding and that receptor internalization is prevented by the NTSR2 specific antagonist levocabastine (Nouel et al., 1999; Ayala-Sarmiento et al., 2015). Like for other GPCRs, receptor internalization plays critical roles in the signaling pathway (Gendron et al., 2004). Finally, it has also been shown that the mouse NTSR2 recycles to the cell membrane (Martin et al., 2002). While nothing is known at this stage for NTSR2 internalization and recycling in brain endothelial cells, this receptor could be involved in NT endocytosis, intracellular release of NT and recycling at the cell membrane, meeting 
the conditions for NT transcytosis across the BBB if these functional properties were confirmed in brain endothelial cells. The limited effects of NT on hypothermia, pain modulation, and behavior when administered i.v. compared to i.c. administration, are related at least in part to poor blood stability and low half-life. Stable NT analogues appear to elicit central effects when administered i.v. (Kokko et al., 2005; reviewed in Boules et al., 2006), suggesting trans-BBB transport. The potential of the VH-N412 vectorized NT to alleviate astrocyte reactivity in vitro suggests that peripheral NT transported across the BBB or NT endogenously produced in the CNS could modulate neuro-inflammation.

\section{NTSR2 is expressed as immediate early gene in glial cells stimulated with proinflammatory} factors

The transient and rapid upregulation of NTSR2 and NTSR3 mRNA after treatment with proinflammatory agents such as LPS and IL1 $\beta$ led us to question whether these NTSRs could be categorized as IEGs. Conditions for IEG classification are that the gene's mRNA levels are rapidly -in general within an hour- and transiently increased, in response to different cell stimuli. In addition, this upregulation should be independent of de novo protein synthesis (Mehendale \& Apte, 2009; Fowler et al., 2011; Bahrami \& Drabløs, 2016). Our results show that the NTSR2 and NTSR3 mRNA expression levels that were increased as early as $1 \mathrm{~h}$ after LPS were unaltered by CHX. The inflammation mechanisms or pathways involved in rapid induction of NTSR2 and NTSR3 expression remain unknown. It will be therefore essential to dissect and understand the properties of these new IEGs, how they are activated and modulated in response to biological stimuli, and how they impact downstream molecular processes and biological responses. It has been reported that several extracellular signals can activate different cellular pathways that upregulate transcription factors and IEGs. Depending on the cellular context and experimental conditions, the RhoA-actin, ERK and P38 MAPK and PI3K pathways have been implicated in the activation of transcription factors, leading to induction of IEGs (Fowler et al., 2011; Bahrami \& Drabløs, 2016). One may hypothesize that NTSR2 and NTSR3 mRNA rapid induction in inflamed glial cells is mediated via one or several of these reported pathways.

IEGs encode different groups of genes including transcription factors, growth factors, cytoskeleton proteins, and receptors such as the NR4A subfamily of nuclear receptors 
(NR4A1, NR4A2 and NR4A3 (Martínez-González \& Badimon, 2005; Mehendale \& Apte, 2009; Zhao \& Bruemmer, 2010). In line with our data, several studies revealed that the NR4A subfamily responds to inflammation (Maxwell \& Muscat, 2006), similar to NTSR2 and NTSR3. The NR4A1, NR4A2 and NR4A3 are rapidly upregulated in macrophages after LPS stimulation (Barish et al., 2005; Pei et al., 2005; Maxwell \& Muscat, 2006), and NR4A1 is also induced by several cytokines (Pei et al., 2005; Maxwell \& Muscat, 2006). In addition, there is evidence for a relationship between the NR4A upregulation and the Nuclear factor NF-kB, one of the major mediators involved in the inflammatory pathway (Pei et al., 2005; Maxwell \& Muscat, 2006). Further studies will be required to decipher the links between the immediate early responses of NTSR2 and NTSR3 and astroglial inflammation.

It is well established that IEGs play important roles in cell growth, differentiation, immune system responses, learning and memory long-term potentiation, inflammation, vascular reorganization and also in diseases (Davis et al., 2003; Plath et al., 2006; Mehendale \& Apte, 2009; Bahrami \& Drabløs, 2016). In the immune system several IEGs have been shown to play important roles in transmitting the activation signal downstream via transcription factors to dictate expression patterns of particular target genes with immunological significance. It is the case for example for Zif-268/egr-1 shown to play a role in immune responses by regulating downstream gene targets encoding interleukin-2 (IL-2), CD44, ICAM-1, tumor necrosis factor (TNF) and NR4A1 in immune cells such as macrophages, B and T lymphocytes (McMahon \& Monroe, 1996; Bahrami \& Drabløs, 2016). Microglia and astroglia can be considered as part of the CNS immune system that respond to and release various proinflammatory factors such as cytokines and chemokines (Lokensgard et al., 2002). Interestingly, in addition to the induction of NTSR2 and NTSR3 IEGs, our data showed that the transcription factor Zif-268/egr-1 IEG is also rapidly induced in glial cells treated with LPS, similar to observations in activated immune cells (Bahrami \& DrabløS, 2016). Furthermore, in our study, several other inflammatory markers including GFAP, MCP1/ccl2, but also Iba1 and IL1ß (data not shown) were also induced by LPS in activated glial cells. It is appealing to suggest that Zif-268/egr-1 may play a role in the triggering of the immune response in activated glial cells and that the induction of Zif-268/egr-1 involves pathways similar to those -or is involved in the pathway- leading to the expression of NTSR2, NTSR3 and other immune response factors mentioned above. 


\section{CONCLUSION}

In all, our work demonstrates the involvement of the neurotensinergic system in the parenchymal glia and glio-vascular unit in conditions of neurological diseases. Our results show that NTSR2 is expressed as an IEG in glial cells in response to proinflammatory factors and is implicated in astroglial and perivascular inflammation. An NT analog down regulates glial inflammation suggesting that NTSR2 may regulate glial responses to injury and that targeting the NTSR2 receptor may open new avenues in the regulation of neuroinflammation. 


\section{REFERENCES}

Abbott, N. J., Rönnbäck, L., \& Hansson, E. (2006). Astrocyte-endothelial interactions at the blood-brain barrier. Nature Reviews. Neuroscience, 7(1), 41-53. https://doi.org/10.1038/nrn1824

Akcan, A., Muhtaroglu, S., Akgun, H., Akyildiz, H., Kucuk, C., Sozuer, E., Yurci, A., \& Yilmaz, N. (2008). Ameliorative effects of bombesin and neurotensin on trinitrobenzene sulphonic acid-induced colitis, oxidative damage and apoptosis in rats. World Journal of Gastroenterology, 14(8), 1222-1230. https://doi.org/10.3748/wjg.14.1222

Alberini, C. M. (2008). The role of protein synthesis during the labile phases of memory: Revisiting the skepticism. Neurobiology of Learning and Memory, 89(3), 234-246. https://doi.org/10.1016/j.nlm.2007.08.007

Ando, T., Kato, R., \& Honda, H. (2019). Identification of an early cell fate regulator by detecting dynamics in transcriptional heterogeneity and co-regulation during astrocyte differentiation. NPJ Systems Biology and Applications, 5:18. https://doi.org/10.1038/s41540-019-0095-2

Armulik, A., Genové, G., \& Betsholtz, C. (2011). Pericytes: Developmental, physiological, and pathological perspectives, problems, and promises. Developmental Cell, 21(2), 193215. https://doi.org/10.1016/j.devcel.2011.07.001

Ayala-Sarmiento, A. E., Martinez-Fong, D., \& Segovia, J. (2015). The Internalization of Neurotensin by the Low-Affinity Neurotensin Receptors (NTSR2 and vNTSR2) Activates ERK 1/2 in Glioma Cells and Allows Neurotensin-Polyplex Transfection of tGAS1. Cellular and Molecular Neurobiology, 35(6), 785-795. https://doi.org/10.1007/s10571-015-0172-z 
Babcock, A. M., Baker, D. A., Hallock, N. L., Lovec, R., Lynch, W. C., \& Peccia, J. C. (1993).

Neurotensin-induced hypothermia prevents hippocampal neuronal damage and increased locomotor activity in ischemic gerbils. Brain Research Bulletin, 32(4), 373378. https://doi.org/10.1016/0361-9230(93)90202-m

Bahrami, S., \& Drabløs, F. (2016). Gene regulation in the immediate-early response process. Advances in Biological Regulation, 62, 37-49. https://doi.org/10.1016/j.jbior.2016.05.001

Barish, G. D., Downes, M., Alaynick, W. A., Yu, R. T., Ocampo, C. B., Bookout, A. L., Mangelsdorf, D. J., \& Evans, R. M. (2005). A Nuclear Receptor Atlas: Macrophage activation. Molecular Endocrinology (Baltimore, Md.), 19(10), 2466-2477. https://doi.org/10.1210/me.2004-0529

Béraud-Dufour, S., Coppola, T., Massa, F., \& Mazella, J. (2009). Neurotensin receptor-2 and 3 are crucial for the anti-apoptotic effect of neurotensin on pancreatic beta-TC3 cells. The International Journal of Biochemistry \& Cell Biology, 41(12), 2398-2402. https://doi.org/10.1016/j.biocel.2009.04.002

Boules, M., Fredrickson, P., \& Richelson, E. (2006). Bioactive analogs of neurotensin: Focus on CNS effects. Peptides, 27(10), 2523-2533.

https://doi.org/10.1016/j.peptides.2005.12.018

Boules, M., Li, Z., Smith, K., Fredrickson, P., \& Richelson, E. (2013). Diverse roles of neurotensin agonists in the central nervous system. Frontiers in Endocrinology, 4, 36. https://doi.org/10.3389/fendo.2013.00036

Boulland, J.-L., Ferhat, L., Tallak Solbu, T., Ferrand, N., Chaudhry, F. A., Storm-Mathisen, J., \& Esclapez, M. (2007). Changes in vesicular transporters for gamma-aminobutyric acid and glutamate reveal vulnerability and reorganization of hippocampal neurons 
following pilocarpine-induced seizures. The Journal of Comparative Neurology, 503(3), 466-485. https://doi.org/10.1002/cne.21384

Cahoy, J. D., Emery, B., Kaushal, A., Foo, L. C., Zamanian, J. L., Christopherson, K. S., Xing, Y., Lubischer, J. L., Krieg, P. A., Krupenko, S. A., Thompson, W. J., \& Barres, B. A. (2008). A transcriptome database for astrocytes, neurons, and oligodendrocytes: A new resource for understanding brain development and function. The Journal of Neuroscience, 28(1), 264-278. https://doi.org/10.1523/JNEUROSCI.4178-07.2008

Camby, I., Salmon, I., Bourdel, E., Nagy, N., Danguy, A., Brotchi, J., Pasteels, J. L., Martinez, J., \& Kiss, R. (1996). Neurotensin-mediated effects on astrocytic tumor cell proliferation. Neuropeptides, 30(2), 133-139. https://doi.org/10.1016/s0143-4179(96)90080-3

Castagliuolo, I., Wang, C. C., Valenick, L., Pasha, A., Nikulasson, S., Carraway, R. E., \& Pothoulakis, C. (1999). Neurotensin is a proinflammatory neuropeptide in colonic inflammation. The Journal of Clinical Investigation, 103(6), 843-849.

https://doi.org/10.1172/JCl4217

Chalon, P., Vita, N., Kaghad, M., Guillemot, M., Bonnin, J., Delpech, B., Le Fur, G., Ferrara, P., \& Caput, D. (1996). Molecular cloning of a levocabastine-sensitive neurotensin binding site. FEBS Letters, 386(2-3), 91-94. https://doi.org/10.1016/00145793(96)00397-3

Chen, C., Duan, Z., Yuan, Y., Li, R., Pang, L., Liang, J., Xu, X., \& Wang, J. (2017). Peptide-22 and Cyclic RGD Functionalized Liposomes for Glioma Targeting Drug Delivery Overcoming BBB and BBTB. ACS Applied Materials \& Interfaces, 9(7), 5864-5873.

https://doi.org/10.1021/acsami.6b15831

Chen, Z., Duan, R.-S., Quezada, H. C., Mix, E., Nennesmo, I., Adem, A., Winblad, B., \& Zhu, J. (2005). Increased microglial activation and astrogliosis after intranasal administration 
of kainic acid in C57BL/6 mice. Journal of Neurobiology, 62(2), 207-218.

https://doi.org/10.1002/neu.20099

Choi, J., \& Koh, S. (2008). Role of Brain Inflammation in Epileptogenesis. Yonsei Medical Journal, 49(1), 1-18. https://doi.org/10.3349/ymj.2008.49.1.1

Clifford, D. B., Olney, J. W., Maniotis, A., Collins, R. C., \& Zorumski, C. F. (1987). The functional anatomy and pathology of lithium-pilocarpine and high-dose pilocarpine seizures. Neuroscience, 23(3), 953-968. https://doi.org/10.1016/03064522(87)90171-0

Clynen, E., Swijsen, A., Raijmakers, M., Hoogland, G., \& Rigo, J.-M. (2014). Neuropeptides as targets for the development of anticonvulsant drugs. Molecular Neurobiology, 50(2), 626-646. https://doi.org/10.1007/s12035-014-8669-x

Cochran, B. H., Zullo, J., Verma, I. M., \& Stiles, C. D. (1984). Expression of the c-fos gene and of an fos-related gene is stimulated by platelet-derived growth factor. Science (New York, N.Y.), 226(4678), 1080-1082. https://doi.org/10.1126/science.6093261

David, M., Lécorché, P., Masse, M., Faucon, A., Abouzid, K., Gaudin, N., Varini, K., Gassiot, F., Ferracci, G., Jacquot, G., Vlieghe, P., \& Khrestchatisky, M. (2018). Identification and characterization of highly versatile peptide-vectors that bind non-competitively to the low-density lipoprotein receptor for in vivo targeting and delivery of small molecules and protein cargos. Plos One, 13(2), e0191052. https://doi.org/10.1371/journal.pone.0191052

Davis, S., Bozon, B., \& Laroche, S. (2003). How necessary is the activation of the immediate early gene zif268 in synaptic plasticity and learning? Behavioural Brain Research, 142(1-2), 17-30. https://doi.org/10.1016/s0166-4328(02)00421-7 
Ding, M., Haglid, K. G., \& Hamberger, A. (2000). Quantitative immunochemistry on neuronal loss, reactive gliosis and BBB damage in cortex/striatum and hippocampus/amygdala after systemic kainic acid administration. Neurochemistry International, 36(4-5), 313-318. https://doi.org/10.1016/s0197-0186(99)00139-4

Ding, S., Fellin, T., Zhu, Y., Lee, S.-Y., Auberson, Y. P., Meaney, D. F., Coulter, D. A., Carmignoto, G., \& Haydon, P. G. (2007). Enhanced astrocytic Ca2+ signals contribute to neuronal excitotoxicity after status epilepticus. The Journal of Neuroscience, 27(40), 10674-10684. https://doi.org/10.1523/JNEUROSCI.2001-07.2007

Dinocourt, C., Petanjek, Z., Freund, T. F., Ben-Ari, Y., \& Esclapez, M. (2003). Loss of interneurons innervating pyramidal cell dendrites and axon initial segments in the CA1 region of the hippocampus following pilocarpine-induced seizures. The Journal of Comparative Neurology, 459(4), 407-425. https://doi.org/10.1002/cne.10622

Dobner, P. R. (2005). Multitasking with neurotensin in the central nervous system. Cellular and Molecular Life Sciences: CMLS, 62(17), 1946-1963. https://doi.org/10.1007/s00018-005-5128-x

Drislane, F. W., Blum, A. S., Lopez, M. R., Gautam, S., \& Schomer, D. L. (2009). Duration of refractory status epilepticus and outcome: Loss of prognostic utility after several hours. Epilepsia, 50(6), 1566-1571. https://doi.org/10.1111/j.1528-

\subsubsection{3.x}

Dulken, B. W., Leeman, D. S., Boutet, S. C., Hebestreit, K., \& Brunet, A. (2017). Single cell transcriptomic analysis defines heterogeneity and transcriptional dynamics in the adult neural stem cell lineage. Cell Reports, 18(3), 777-790.

https://doi.org/10.1016/j.celrep.2016.12.060 
Dusart, I., Marty, S., \& Peschanski, M. (1991). Glial changes following an excitotoxic lesion in the CNS--II. Astrocytes. Neuroscience, 45(3), 541-549. https://doi.org/10.1016/03064522(91)90269-t

ElAli, A., Thériault, P., \& Rivest, S. (2014). The role of pericytes in neurovascular unit remodeling in brain disorders. International Journal of Molecular Sciences, 15(4), 6453-6474. https://doi.org/10.3390/ijms15046453

Ferhat, L., Esclapez, M., Represa, A., Fattoum, A., Shirao, T., \& Ben-Ari, Y. (2003). Increased levels of acidic calponin during dendritic spine plasticity after pilocarpine-induced seizures. Hippocampus, 13(7), 845-858. https://doi.org/10.1002/hipo.10136

Fowler, T., Sen, R., \& Roy, A. L. (2011). Regulation of Primary Response Genes. Molecular Cell, 44(3), 348-360. https://doi.org/10.1016/j.molcel.2011.09.014

Friry, C., Feliciangeli, S., Richard, F., Kitabgi, P., \& Rovere, C. (2002). Production of Recombinant Large Proneurotensin/Neuromedin N-Derived Peptides and Characterization of Their Binding and Biological Activity. Biochemical and Biophysical Research Communications, 290(4), 1161-1168.

https://doi.org/10.1006/bbrc.2001.6308

Gahete, M. D., Rubio, A., Córdoba-Chacón, J., Gracia-Navarro, F., Kineman, R. D., Avila, J., Luque, R. M., \& Castaño, J.P. (2010). Expression of the ghrelin and neurotensin systems is altered in the temporal lobe of Alzheimer's disease patients. Journal of Alzheimer's Disease, 22(3), 819-828. https://doi.org/10.3233/JAD-2010-100873

Garzillo, C., \& Mello, L. (2002). Characterization of reactive astrocytes in the chronic phase of the pilocarpine model of epilepsy. Epilepsia, 43, 107-109. https://doi.org/10.1046/j.1528-1157.43.s.5.40.x 
Gashler, A., \& Sukhatme, V. P. (1995). Early growth response protein 1 (Egr-1): Prototype of a zinc-finger family of transcription factors. Progress in Nucleic Acid Research and Molecular Biology, 50, 191-224. https://doi.org/10.1016/s0079-6603(08)60815-6

Gendron, L., Perron, A., Payet, M. D., Gallo-Payet, N., Sarret, P., \& Beaudet, A. (2004). Lowaffinity neurotensin receptor (NTS2) signaling: Internalization-dependent activation of extracellular signal-regulated kinases 1/2. Molecular Pharmacology, 66(6), 14211430. https://doi.org/10.1124/mol.104.002303

Goffin, K., Nissinen, J., Van Laere, K., \& Pitkänen, A. (2007). Cyclicity of spontaneous recurrent seizures in pilocarpine model of temporal lobe epilepsy in rat. Experimental Neurology, 205(2), 501-505. https://doi.org/10.1016/j.expneurol.2007.03.008

Granier, C., van Rietschoten, J., Kitabgi, P., Poustis, C., \& Freychet, P. (1982). Synthesis and characterization of neurotensin analogues for structure/activity relationship studies. Acetyl-neurotensin-(8-13) is the shortest analogue with full binding and pharmacological activities. European Journal of Biochemistry, 124(1), 117-124. https://doi.org/10.1111/j.1432-1033.1982.tb05913.x

Green, B. R., White, K. L., McDougle, D. R., Zhang, L., Klein, B., Scholl, E. A., Pruess, T. H., White, H. S., \& Bulaj, G. (2010). Introduction of lipidization-cationization motifs affords systemically bioavailable neuropeptide $Y$ and neurotensin analogs with anticonvulsant activities. Journal of Peptide Science: An Official Publication of the European Peptide Society, 16(9), 486-495. https://doi.org/10.1002/psc.1266

Greenfield, E. M., Horowitz, M. C., \& Lavish, S. A. (1996). Stimulation by parathyroid hormone of interleukin-6 and leukemia inhibitory factor expression in osteoblasts is an immediate-early gene response induced by CAMP signal transduction. The Journal 
of Biological Chemistry, 271(18), 10984-10989.

https://doi.org/10.1074/jbc.271.18.10984

Hawkins, M. F., Barkemeyer, C. A., \& Tulley, R. T. (1986). Synergistic effects of dopamine agonists and centrally administered neurotensin on feeding. Pharmacology, Biochemistry, and Behavior, 24(5), 1195-1201. https://doi.org/10.1016/00913057(86)90170-x

Hernandez-Chan, N. G., Bannon, M. J., Orozco-Barrios, C. E., Escobedo, L., Zamudio, S., De la Cruz, F., Gongora-Alfaro, J. L., Armendáriz-Borunda, J., Reyes-Corona, D., EspadasAlvarez, A. J., Flores-Martínez, Y. M., Ayala-Davila, J., Hernandez-Gutierrez, M. E., Pavón, L., García-Villegas, R., Nadella, R., \& Martinez-Fong, D. (2015). Neurotensinpolyplex-mediated brain-derived neurotrophic factor gene delivery into nigral dopamine neurons prevents nigrostriatal degeneration in a rat model of early Parkinson's disease. Journal of Biomedical Science, 22, 59. https://doi.org/10.1186/s12929-015-0166-7

Herschman, H. R. (1991). Primary response genes induced by growth factors and tumor promoters. Annual Review of Biochemistry, 60, 281-319. https://doi.org/10.1146/annurev.bi.60.070191.001433

Hol, E. M., \& Pekny, M. (2015). Glial fibrillary acidic protein (GFAP) and the astrocyte intermediate filament system in diseases of the central nervous system. Current Opinion in Cell Biology, 32, 121-130. https://doi.org/10.1016/j.ceb.2015.02.004 Hughes, P., Beilharz, E., Gluckman, P., \& Dragunow, M. (1993). Brain-derived neurotrophic factor is induced as an immediate early gene following $\mathrm{N}$-methyl-d-aspartate receptor activation. Neuroscience, 57(2), 319-328. https://doi.org/10.1016/0306$4522(93) 90065-\mathrm{N}$ 
Izant, J. G., \& McIntosh, J. R. (1980). Microtubule-associated proteins: A monoclonal antibody to MAP2 binds to differentiated neurons. Proceedings of the National Academy of Sciences of the United States of America, 77(8), 4741-4745. https://doi.org/10.1073/pnas.77.8.4741

Jacquot, G., Lécorché, P., Malcor, J.-D., Laurencin, M., Smirnova, M., Varini, K., Malicet, C., Gassiot, F., Abouzid, K., Faucon, A., David, M., Gaudin, N., Masse, M., Ferracci, G., Dive, V., Cisternino, S., \& Khrestchatisky, M. (2016). Optimization and in Vivo Validation of Peptide Vectors Targeting the LDL Receptor. Molecular Pharmaceutics, 13(12), 4094-4105. https://doi.org/10.1021/acs.molpharmaceut.6b00687

Jurcovicova, J. (2014). Glucose transport in brain-Effect of inflammation. Endocrine Regulations, 48(1), 35-48. https://doi.org/10.4149/endo_2014_01_35

Kleczkowska, P., \& Lipkowski, A. W. (2013). Neurotensin and neurotensin receptors: Characteristic, structure-activity relationship and pain modulation--a review. European Journal of Pharmacology, 716(1-3), 54-60. https://doi.org/10.1016/j.ejphar.2013.03.004

Knake, S., Hamer, H. M., \& Rosenow, F. (2009). Status epilepticus: A critical review. Epilepsy \& Behavior, 15(1), 10-14. https://doi.org/10.1016/j.yebeh.2009.02.027

Kokko, K. P., Hadden, M. K., Price, K. L., Orwig, K. S., See, R. E., \& Dix, T. A. (2005). In vivo behavioral effects of stable, receptor-selective neurotensin[8-13] analogues that cross the blood-brain barrier. Neuropharmacology, 48(3), 417-425. https://doi.org/10.1016/j.neuropharm.2004.10.008

Lau, L. F., \& Nathans, D. (1991) in The Hormonal Control of Gene Transcription (Cohen, P., and Foulkes, J. G., eds) pp. 257-293, Elsevier, Amsterdam. 
Lee, H.-K., Zhang, L., Smith, M. D., White, H. S., \& Bulaj, G. (2009). Glycosylated neurotensin analogues exhibit sub-picomolar anticonvulsant potency in a pharmacoresistant model of epilepsy. ChemMedChem, 4(3), 400-405. https://doi.org/10.1002/cmdc.200800421

Lee, T. S., Eid, T., Mane, S., Kim, J. H., Spencer, D. D., Ottersen, O. P., \& de Lanerolle, N. C. (2004). Aquaporin-4 is increased in the sclerotic hippocampus in human temporal lobe epilepsy. Acta Neuropathologica, 108(6), 493-502. https://doi.org/10.1007/s00401-004-0910-7

Lépée-Lorgeoux, I., Betancur, C., Rostène, W., \& Pélaprat, D. (1999). Differential ontogenetic patterns of levocabastine-sensitive neurotensin NT2 receptors and of NT1 receptors in the rat brain revealed by in situ hybridization. Brain Research. Developmental Brain Research, 113(1-2), 115-131. https://doi.org/10.1016/s0165-3806(99)00009-7

Lokensgard, J. R., Cheeran, M. C.-J., Hu, S., Gekker, G., \& Peterson, P. K. (2002). Glial cell responses to herpesvirus infections: Role in defense and immunopathogenesis. The Journal of Infectious Diseases, 186 Suppl 2, S171-179.

https://doi.org/10.1086/344272

Malcor, J.-D., Payrot, N., David, M., Faucon, A., Abouzid, K., Jacquot, G., Floquet, N., Debarbieux, F., Rougon, G., Martinez, J., Khrestchatisky, M., Vlieghe, P., \& Lisowski, V. (2012). Chemical optimization of new ligands of the low-density lipoprotein receptor as potential vectors for central nervous system targeting. Journal of Medicinal Chemistry, 55(5), 2227-2241. https://doi.org/10.1021/jm2014919

Manning, C. E., Eagle, A. L., Kwiatkowski, C. C., Achargui, R., Woodworth, H., Potter, E., Ohnishi, Y., Leinninger, G. M., \& Robison, A. J. (2019). Hippocampal Subgranular Zone 
FosB Expression Is Critical for Neurogenesis and Learning. Neuroscience, 406, 225233. https://doi.org/10.1016/j.neuroscience.2019.03.022

Martin, Stéphane, Vincent, J.-P., \& Mazella, J. (2002). Recycling ability of the mouse and the human neurotensin type 2 receptors depends on a single tyrosine residue. Journal of Cell Science, 115(Pt 1), 165-173.

Martin, Stephane, Vincent, J.-P., \& Mazella, J. (2003). Involvement of the neurotensin receptor-3 in the neurotensin-induced migration of human microglia. The Journal of Neuroscience, 23(4), 1198-1205. https://doi.org/10.1523/jneurosci.23-0401198.2003

Martínez-González, J., \& Badimon, L. (2005). The NR4A subfamily of nuclear receptors: New early genes regulated by growth factors in vascular cells. Cardiovascular Research, 65(3), 609-618. https://doi.org/10.1016/j.cardiores.2004.10.002

Maxwell, M. A., \& Muscat, G. E. O. (2006). The NR4A subgroup: Immediate early response genes with pleiotropic physiological roles. Nuclear Receptor Signaling, 4, e002. https://doi.org/10.1621/nrs.04002

Mazella, J. (2001). Sortilin/neurotensin receptor-3: A new tool to investigate neurotensin signaling and cellular trafficking? Cellular Signalling, 13(1), 1-6. https://doi.org/10.1016/s0898-6568(00)00130-3

McMahon, S. B., \& Monroe, J. G. (1996). The role of early growth response gene 1 (egr-1) in regulation of the immune response. Journal of Leukocyte Biology, 60(2), 159-166. https://doi.org/10.1002/jlb.60.2.159

Mehendale, H. M., \& Apte, U. (2009). 'Hepatic Defenses Against Toxicity: Liver Regeneration and Tissue Repair' In Comprehensive Toxicology (2nd ed., Editor-in-Chief: Robert A. Roth). Elsevier, Oxford. 
Molino, Y., David, M., Varini, K., Jabès, F., Gaudin, N., Fortoul, A., Bakloul, K., Masse, M., Bernard, A., Drobecq, L., Lécorché, P., Temsamani, J., Jacquot, G., \& Khrestchatisky, M. (2017). Use of LDL receptor-targeting peptide vectors for in vitro and in vivo cargo transport across the blood-brain barrier. FASEB, 31(5), 1807-1827. https://doi.org/10.1096/fj.201600827R

Mouri, G., Jimenez-Mateos, E., Engel, T., Dunleavy, M., Hatazaki, S., Paucard, A., Matsushima, S., Taki, W., \& Henshall, D. C. (2008). Unilateral hippocampal CA3predominant damage and short latency epileptogenesis after intra-amygdala microinjection of kainic acid in mice. Brain Research, 1213, 140-151. https://doi.org/10.1016/j.brainres.2008.03.061

Mustain, W. C., Rychahou, P. G., \& Evers, B. M. (2011). The role of neurotensin in physiologic and pathologic processes. Current Opinion in Endocrinology, Diabetes, and Obesity, 18(1), 75-82. https://doi.org/10.1097/MED.0b013e3283419052

Navarro, V., Martin, S., \& Mazella, J. (2006). Internalization-dependent regulation of HT29 cell proliferation by neurotensin. Peptides, 27(10), 2502-2507. https://doi.org/10.1016/j.peptides.2006.04.028

Nemeroff, C. B., Bissette, G., Manberg, P. J., Osbahr, A. J., Breese, G. R., \& Prange, A. J. (1980). Neurotensin-induced hypothermia: Evidence for an interaction with dopaminergic systems and the hypothalamic--pituitary--thyroid axis. Brain Research, 195(1), 69-84. https://doi.org/10.1016/0006-8993(80)90867-7

Nouel, D., Sarret, P., Vincent, J. P., Mazella, J., \& Beaudet, A. (1999). Pharmacological, molecular and functional characterization of glial neurotensin receptors. Neuroscience, 94(4), 1189-1197. https://doi.org/10.1016/s0306-4522(99)00354-1 
Ohsawa, K., Imai, Y., Sasaki, Y., \& Kohsaka, S. (2004). Microglia/macrophage-specific protein Iba1 binds to fimbrin and enhances its actin-bundling activity. Journal of Neurochemistry, 88(4), 844-856. https://doi.org/10.1046/j.1471-4159.2003.02213.x

Ouyang, Q., Gong, X., Xiao, H., Zhou, J., Xu, M., Dai, Y., Xu, L., Feng, H., Cui, H., \& Yi, L. (2015). Neurotensin promotes the progression of malignant glioma through NTSR1 and impacts the prognosis of glioma patients. Molecular Cancer, 14, 21. https://doi.org/10.1186/s12943-015-0290-8

Palacios, J. M., Pazos, A., Dietl, M. M., Schlumpf, M., \& Lichtensteiger, W. (1988). The ontogeny of brain neurotensin receptors studied by autoradiography. Neuroscience, 25(1), 307-317. https://doi.org/10.1016/0306-4522(88)90028-0

Pang, Y., Cai, Z., \& Rhodes, P. G. (2001). Analysis of genes differentially expressed in astrocytes stimulated with lipopolysaccharide using cDNA arrays. Brain Research, 914(1-2), 15-22. https://doi.org/10.1016/s0006-8993(01)02766-4

Patel, A. B., Tsilioni, I., Leeman, S. E., \& Theoharides, T. C. (2016). Neurotensin stimulates sortilin and mTOR in human microglia inhibitable by methoxyluteolin, a potential therapeutic target for autism. Proceedings of the National Academy of Sciences of the United States of America, 113(45), E7049-E7058.

https://doi.org/10.1073/pnas.1604992113

Paxinos, G., \& Franklin, K. (2019). The Mouse Brain in stereotaxic coordinates (5th ed.). Academic Press, Inc., San Diego, USA.

Paxinos, G., \& Watson, C. (1998). The Rat Brain in stereotaxic coordinates (5th ed.). Academic Press, Inc., San Diego, USA.

Pei, L., Castrillo, A., Chen, M., Hoffmann, A., \& Tontonoz, P. (2005). Induction of NR4A orphan nuclear receptor expression in macrophages in response to inflammatory 
stimuli. The Journal of Biological Chemistry, 280(32), 29256-29262.

https://doi.org/10.1074/jbc.M502606200

Perron, A., Sharif, N., Gendron, L., Lavallée, M., Stroh, T., Mazella, J., \& Beaudet, A. (2006).

Sustained neurotensin exposure promotes cell surface recruitment of NTS2

receptors. Biochemical and Biophysical Research Communications, 343(3), 799-808.

https://doi.org/10.1016/j.bbrc.2006.03.047

Plath, N., Ohana, O., Dammermann, B., Errington, M. L., Schmitz, D., Gross, C., Mao, X., Engelsberg, A., Mahlke, C., Welzl, H., Kobalz, U., Stawrakakis, A., Fernandez, E., Waltereit, R., Bick-Sander, A., Therstappen, E., Cooke, S. F., Blanquet, V., Wurst, W., ... Kuhl, D. (2006). Arc/Arg3.1 is essential for the consolidation of synaptic plasticity and memories. Neuron, 52(3), 437-444.

https://doi.org/10.1016/j.neuron.2006.08.024

Russjan, E., \& Kaczyńska, K. (2019). Beneficial Effects of Neurotensin in Murine Model of Hapten-Induced Asthma. International Journal of Molecular Sciences, 20(20). https://doi.org/10.3390/ijms20205025

Saada, S., Marget, P., Fauchais, A.-L., Lise, M.-C., Chemin, G., Sindou, P., Martel, C., Delpy, L., Vidal, E., Jaccard, A., Troutaud, D., Lalloué, F., \& Jauberteau, M.-O. (2012). Differential expression of neurotensin and specific receptors, NTSR1 and NTSR2, in normal and malignant human B lymphocytes. Journal of Immunology, 189(11), 52935303. https://doi.org/10.4049/jimmunol.1102937

Sarret, P., Beaudet, A., Vincent, J. P., \& Mazella, J. (1998). Regional and cellular distribution of low affinity neurotensin receptor mRNA in adult and developing mouse brain. The Journal of Comparative Neurology, 394(3), 344-356. 
https://doi.org/10.1002/(SICI)1096-9861(19980511)394:3\%3C344::AID-

\section{CNE6\%3E3.0.CO;2-1}

Sarret, Philippe, \& Beaudet, A. (2002). Chapter VI: Neurotensin receptors in the central nervous system In Handbook of Chemical Neuroanatomy Vol. 20, pp. 323-400 (R. Quirion, A. Björklund and T. Hökfelt, eds.). Elsevier. https://doi.org/10.1016/S09248196(02)80008-2

Sarret, Philippe, Gendron, L., Kilian, P., Nguyen, H. M. K., Gallo-Payet, N., Payet, M.-D., \& Beaudet, A. (2002). Pharmacology and functional properties of NTS2 neurotensin receptors in cerebellar granule cells. The Journal of Biological Chemistry, 277(39), 36233-36243. https://doi.org/10.1074/jbc.M202586200

Sarret, Philippe, Perron, A., Stroh, T., \& Beaudet, A. (2003). Immunohistochemical distribution of NTS2 neurotensin receptors in the rat central nervous system. The Journal of Comparative Neurology, 461(4), 520-538.

https://doi.org/10.1002/cne.10718

Sbai, O., Khrestchatisky, M., Esclapez, M., \& Ferhat, L. (2012). Drebrin A expression is altered after pilocarpine-induced seizures: Time course of changes is consistent for a role in the integrity and stability of dendritic spines of hippocampal granule cells. Hippocampus, 22(3), 477-493. https://doi.org/10.1002/hipo.20914

Schauwecker, P. E., \& Steward, O. (1997). Genetic determinants of susceptibility to excitotoxic cell death: Implications for gene targeting approaches. Proceedings of the National Academy of Sciences of the United States of America, 94(8), 4103-4108. https://doi.org/10.1073/pnas.94.8.4103 
Seifert, G., Carmignoto, G., \& Steinhäuser, C. (2010). Astrocyte dysfunction in epilepsy. Brain Research Reviews, 63(1-2), 212-221.

https://doi.org/10.1016/j.brainresrev.2009.10.004

Shapiro, L. A., Wang, L., \& Ribak, C. E. (2008). Rapid astrocyte and microglial activation following pilocarpine-induced seizures in rats. Epilepsia, 49 Suppl 2, 33-41. https://doi.org/10.1111/j.1528-1167.2008.01491.x

Sharma, A. K., Reams, R. Y., Jordan, W. H., Miller, M. A., Thacker, H. L., \& Snyder, P. W. (2007). Mesial temporal lobe epilepsy: Pathogenesis, induced rodent models and lesions. Toxicologic Pathology, 35(7), 984-999. https://doi.org/10.1080/01926230701748305

Sharma, R. P., Janicak, P. G., Bissette, G., \& Nemeroff, C. B. (1997). CSF neurotensin concentrations and antipsychotic treatment in schizophrenia and schizoaffective disorder. The American Journal of Psychiatry, 154(7), 1019-1021. https://doi.org/10.1176/ajp.154.7.1019

Shen, Y., Cao, B., Snyder, N. R., Woeppel, K. M., Eles, J. R., \& Cui, X. T. (2018). ROS responsive resveratrol delivery from LDLR peptide conjugated PLA-coated mesoporous silica nanoparticles across the blood-brain barrier. Journal of Nanobiotechnology, 16(1), 13. https://doi.org/10.1186/s12951-018-0340-7

Shults, N. V., Almansour, F. S., Rybka, V., Suzuki, D. I., \& Suzuki, Y. J. (2018). Ligand-mediated dephosphorylation signaling for MAP kinase. Cellular Signalling, 52, 147-154. https://doi.org/10.1016/j.cellsig.2018.09.005

Soussi, R., Boulland, J.-L., Bassot, E., Bras, H., Coulon, P., Chaudhry, F. A., Storm-Mathisen, J., Ferhat, L., \& Esclapez, M. (2015). Reorganization of supramammillary-hippocampal pathways in the rat pilocarpine model of temporal lobe epilepsy: Evidence for axon 
terminal sprouting. Brain Structure \& Function, 220(4), 2449-2468.

https://doi.org/10.1007/s00429-014-0800-2

Sperk, G., Wieser, R., Widmann, R., \& Singer, E. A. (1986). Kainic acid induced seizures:

Changes in somatostatin, substance $P$ and neurotensin. Neuroscience, 17(4), 1117-

1126. https://doi.org/10.1016/0306-4522(86)90081-3

St-Gelais, F., Jomphe, C., \& Trudeau, L.-E. (2006). The role of neurotensin in central nervous system pathophysiology: What is the evidence? Journal of Psychiatry \& Neuroscience, 31(4), 229-245.

Sun, L., \& Ye, R. D. (2012). Role of G protein-coupled receptors in inflammation. Acta Pharmacologica Sinica, 33(3), 342-350. https://doi.org/10.1038/aps.2011.200

Tabarean, I. (2020). Neurotensin induces hypothermia by activating both neuronal neurotensin receptor 1 and astrocytic neurotensin receptor 2 in the median preoptic nucleus. Neuropharmacology, 108069.

https://doi.org/10.1016/j.neuropharm.2020.108069

Tanaka, K., Masu, M., \& Nakanishi, S. (1990). Structure and functional expression of the cloned rat neurotensin receptor. Neuron, 4(6), 847-854.

Torup, L., Borsdal, J., \& Sager, T. (2003). Neuroprotective effect of the neurotensin analogue JMV-449 in a mouse model of permanent middle cerebral ischaemia. Neuroscience Letters, 351(3), 173-176. https://doi.org/10.1016/j.neulet.2003.08.008

Uzunalli, G., Dieterly, A. M., Kemet, C. M., Weng, H.-Y., Soepriatna, A. H., Goergen, C. J., Shinde, A. B., Wendt, M. K., \& Lyle, L. T. (2019). Dynamic transition of the blood-brain barrier in the development of non-small cell lung cancer brain metastases.

Oncotarget, 10(59), 6334-6348. https://doi.org/10.18632/oncotarget.27274 
Vincent, J. P. (1995). Neurotensin receptors: Binding properties, transduction pathways, and structure. Cellular and Molecular Neurobiology, 15(5), 501-512. https://doi.org/10.1007/bf02071313

Vita, N., Oury-Donat, F., Chalon, P., Guillemot, M., Kaghad, M., Bachy, A., Thurneyssen, O., Garcia, S., Poinot-Chazel, C., Casellas, P., Keane, P., Le Fur, G., Maffrand, J. P., Soubrie, P., Caput, D., \& Ferrara, P. (1998). Neurotensin is an antagonist of the human neurotensin NT2 receptor expressed in Chinese hamster ovary cells. European Journal of Pharmacology, 360(2-3), 265-272. https://doi.org/10.1016/s0014-2999(98)00678-5

Walker, N., Lepee-Lorgeoux, I., Fournier, J., Betancur, C., Rostene, W., Ferrara, P., \& Caput, D. (1998). Tissue distribution and cellular localization of the levocabastine-sensitive neurotensin receptor mRNA in adult rat brain. Brain Research. Molecular Brain Research, 57(2), 193-200. https://doi.org/10.1016/s0169-328x(98)00074-6

Williams, F. G., Mullet, M. A., \& Beitz, A. J. (1995). Basal release of Met-enkephalin and neurotensin in the ventrolateral periaqueductal gray matter of the rat: $\mathrm{A}$ microdialysis study of antinociceptive circuits. Brain Research, 690(2), 207-216. https://doi.org/10.1016/0006-8993(95)00554-4

Woodworth, H. L., Perez-Bonilla, P. A., Beekly, B. G., Lewis, T. J., \& Leinninger, G. M. (2018). Identification of Neurotensin Receptor Expressing Cells in the Ventral Tegmental Area across the Lifespan. eNeuro, 5(1). https://doi.org/10.1523/ENEURO.0191-17.2018

Xu, Z., Dziarski, R., Wang, Q., Swartz, K., Sakamoto, K. M., \& Gupta, D. (2001). Bacterial Peptidoglycan-Induced tnf- $\alpha$ Transcription Is Mediated Through the Transcription Factors Egr-1, Elk-1, and NF-kB. The Journal of Immunology, 167(12), 6975-6982. https://doi.org/10.4049/jimmunol.167.12.6975 
Yamaji, Y., Moe, O. W., Miller, R. T., \& Alpern, R. J. (1994). Acid activation of immediate early genes in renal epithelial cells. The Journal of Clinical Investigation, 94(3), 1297-1303. https://doi.org/10.1172/JCl117448

Yamauchi, R., Wada, E., Kamichi, S., Yamada, D., Maeno, H., Delawary, M., Nakazawa, T., Yamamoto, T., \& Wada, K. (2007). Neurotensin type 2 receptor is involved in fear memory in mice. Journal of Neurochemistry, 102(5), 1669-1676.

https://doi.org/10.1111/j.1471-4159.2007.04805.x

Yao, J., Mackman, N., Edgington, T. S., \& Fan, S. T. (1997). Lipopolysaccharide induction of the tumor necrosis factor-alpha promoter in human monocytic cells. Regulation by Egr-1, c-Jun, and NF-kappaB transcription factors. The Journal of Biological Chemistry, 272(28), 17795-17801. https://doi.org/10.1074/jbc.272.28.17795

Zamanian, J. L., Xu, L., Foo, L. C., Nouri, N., Zhou, L., Giffard, R. G., \& Barres, B. A. (2012). Genomic Analysis of Reactive Astrogliosis. Journal of Neuroscience, 32(18), 63916410. https://doi.org/10.1523/JNEUROSCI.6221-11.2012

Zhang, B., Sun, X., Mei, H., Wang, Y., Liao, Z., Chen, J., Zhang, Q., Hu, Y., Pang, Z., \& Jiang, X. (2013). LDLR-mediated peptide-22-conjugated nanoparticles for dual-targeting therapy of brain glioma. Biomaterials, 34(36), 9171-9182. https://doi.org/10.1016/j.biomaterials.2013.08.039

Zhang, Y., Chen, K., Sloan, S. A., Bennett, M. L., Scholze, A. R., O’Keeffe, S., Phatnani, H. P., Guarnieri, P., Caneda, C., Ruderisch, N., Deng, S., Liddelow, S. A., Zhang, C., Daneman, R., Maniatis, T., Barres, B. A., \& Wu, J. Q. (2014). An RNA-sequencing transcriptome and splicing database of glia, neurons, and vascular cells of the cerebral cortex. The Journal of Neuroscience, 34(36), 11929-11947.

https://doi.org/10.1523/JNEUROSCI.1860-14.2014 
Zhao, Y., \& Bruemmer, D. (2010). NR4A Orphan Nuclear Receptors: Transcriptional

Regulators of Gene Expression in Metabolism and Vascular Biology. Arteriosclerosis,

Thrombosis, and Vascular Biology, 30(8), 1535-1541.

https://doi.org/10.1161/ATVBAHA.109.191163 


\section{FIGURE LEGENDS}

Figure 1. NTSR2 protein is mainly expressed in astrocytes and increases in all hippocampal areas following pilocarpine-induced SE. NTSR2 (green) and GFAP (red) double immunolabeling was performed in CTL (A-C, G-I) and pilocarpine-treated rats at day 3 postSE (PILO 3D, D-F, J-L). Cell nuclei were counterstained with DAPI (blue, C and F). Merge corresponds to NTSR2/GFAP/DAPI (C and F). High magnification of the hilus of CTL (G-I) and PILO 3D (J-L) clearly shows NTSR2 immunolabeling in GFAP-positive astrocytes (see arrowheads), with stronger NTSR2 immunolabeling in PILO 3D compared to CTL animals. Note that non-astrocytic (GFAP-negative) NTSR2+ cells, most likely neuronal cells, are visible both in CTL and PILO 3D (G-L, see arrows). NTSR2 immunoreactivity is visible in the cell membrane, in the cell body and processes of astrocytes (see insets). In PILO 3D rats, NTSR2 immunolabeling displayed a more punctate pattern at the cell membrane as well as in the processes (Inset in $\mathrm{J}$ and $\mathrm{L}$ ) compared to CTL rats. Panels I and L correspond to NTSR2/GFAP merged labelling. Scale bars: $450 \mu \mathrm{m}$ in A-F, $10 \mu \mathrm{m}$ in $\mathrm{G}-\mathrm{L}$ and $5 \mu \mathrm{m}$ in insets. O: stratum oriens; $\mathrm{P}$ : pyramidal neurons of $\mathrm{CA} 1, \mathrm{CA} 2$ and $\mathrm{CA} 3$; $\mathrm{R}$ : stratum radiatum; $\mathrm{LM}$ : stratum lacunosum-moleculare; M: molecular layer; DG: dentate gyrus; G granule cell layer of DG; H: hilus of the DG.

Figure 2. Mean intensities of NTSR2 immunolabeling in hippocampal astrocytes at different times following pilocarpine-induced SE, compared to CTL. In the DG (A) and CA3 (C), the highest increase for NTSR2 levels was at 3D post-SE, and at 14D for CA1 (B) compared to CTL. In all three areas, NTSR2 levels were higher in PILO vs CTL rats at all time points post-SE from 3 to 14D, except at 14D post-SE for DG. At 3 months post-SE, NTSR2 levels were significantly reduced in the DG and CA3 compared to CTL, but not in CA1. Astrocytes were detected by GFAP immunolabeling. NTSR2 levels were quantified in cells labeled with both NTSR2 and GFAP and values are given as the mean \pm SEM as a percentage of CTL for each area. Asterisks indicate statistically significant differences: ** $p<0,01$ (oneway ANOVA followed by Tukey's post hoc test).

Figure 3. NTSR2 is not expressed in hippocampal microglial cells in CTL rats and following pilocarpine-induced SE. NTSR2 (green) and Iba1 (red) immunostaining was performed in CTL 
(A-C, G-I) and PILO 3D rats (D-F, J-L). Microglia were detected by Iba1 immunolabeling. Cell nuclei were counterstained with DAPI (blue, C and F). Merge corresponds to NTSR2/Iba1/DAPI (C and F). NTSR2 was not expressed in microglial cells since NTSR2 and Iba1 antibodies stain distinct cells as revealed by high magnification images (G-L, see arrowheads). Scale bars: $450 \mu \mathrm{m}$ in A-F and $10 \mu \mathrm{m}$ in G-L.

Figure 4. NTSR2 protein is expressed in blood vessels and increases following pilocarpineinduced SE. NTSR2 (green) immunostaining was performed in CTL (A-C) and PILO 3D rats (DF). NTSR2 immunoreactivity was present in blood vessel cells of the LM with increased labeling in PILO 3D rats. In addition, several cells around these vessels displayed strong NTSR2 expression compared to CTL rats (arrows). Other dispersed cells in LM expressing NTSR2 are indicated (arrowheads). Cell nuclei were counterstained with DAPI (blue, A-F). Scale bar: $20 \mu \mathrm{m}$ in all panels. G: Mean percentage of NTSR2 fluorescence intensity in DG and LM vessels in CTL and PILO 3D rats. Blood vessels of PILO 3D rats expressed significant NTSR2 levels compared to CTL rats vessels. Values are given as the mean \pm SEM as a percentage of CTL. Asterisks indicate statistically significant differences: $* * * \quad p<0.001$ (Student's $t$-test).

Figure 5. NTSR2 protein is expressed in astrocytic end feet around the blood vessels in the LM. GFAP (red, $A, D, G$ ) and NTSR2 (green, $B, C, E, F, H, I)$ immunolabeling was performed in PILO 3D rats. All astrocytes (A-E, see arrows) around blood vessels expressed NTSR2. F-I show high magnification of the boxed-in area illustrating NTSR2 expression in the end-feet of astrocytes that project on blood vessels of the LM (arrowheads). In addition to astrocytes, other cells in and around the blood vessels expressed NTSR2. Cell nuclei were counterstained with DAPI (blue). Scale bars: $10 \mu \mathrm{m}$ in all panels.

Figure 6. NTSR2 protein is expressed in blood vessel endothelial cells of the LM following pilocarpine-induced SE. NTSR2 (white), CD31 (red) and Collagen IV (green) immunostaining was performed in PILO 3D rats (A-H). I-L show high magnification of the boxed-in area illustrating endothelial cells (red, arrows) and basal lamina (green, arrowheads), revealed with anti-CD31 and -Collagen IV antibodies, respectively. NTSR2 labeling was mainly 
associated with endothelial cells as revealed with CD31 labeling. Cell nuclei were counterstained with DAPI (blue). Scale bars: $20 \mu \mathrm{m}$ in A-H and $10 \mu \mathrm{m}$ in I-L.

Figure 7. NTSR2 protein is virtually absent in blood vessel pericytes of the LM following pilocarpine-induced SE. NTSR2 (white), CD31 (red) and PDGFRß (green) immunostaining was performed in PILO 3D rats (A-H). I-L show high magnification of the boxed-in area illustrating endothelial cells (red) and pericytes (green), revealed with anti-CD31 and -PDGFR $\beta$ antibodies, respectively. Co-labeling (NTSR2/CD31/PDGFRß) confirmed NTSR2 expression in endothelial cells and faint or absent NTSR2 labeling in pericytes. Cell nuclei were counterstained with DAPI (blue). Scale bars: $20 \mu \mathrm{m}$ in A-H and $10 \mu \mathrm{m}$ in I-L.

Figure 8. NTSR2 protein is expressed in primary cultured glial cells. A-D: Double NTSR2 (green, B) and GFAP (red, C) immunofluorescence shows that astrocytes from rat primary glial cultures express NTSR2 within the cell body and at the plasma membrane (see arrowheads). The strong immunostaining found in the cell body likely corresponds to the Golgi apparatus. E-H: NTSR2 (green, F) was also expressed in microglial cells from rat primary glial cultures, identified by Iba1 (red, G). Cell nuclei were counterstained with DAPI (blue, $A, B, D$ \& $E, F, H)$. Merge corresponds to superimposition of DAPI, NTSR2 and GFAP (D), or DAPI, NTSR2 and Iba1 staining (H). I: The fluorescence intensity of NTSR2 labeling in CTL GFAP+ cells was measured and compared to that of CTL Iba1+ cells. The average intensity of NTSR2 was significantly higher in microglial cells compared to astrocytes $(H)$. Values are given as the mean \pm SEM as a percentage of the CTL GFAP+ cells. Asterisk indicates statistically significant difference: * $p<0,05$ (Student's $t$-test). Scale bar: $10 \mu \mathrm{m}$

Figure 9. Inflammation differently affects the expression of neurotensin receptors in glial primary cultures. Histograms showing qRT-PCR quantification of the inflammatory cytokines IL1 $\beta$ (A) and MCP-1/ccl2 mRNA levels (B), after 1, 6 and 24H treatment with either IL1 $(10$ $\mathrm{ng} / \mathrm{ml})$ or LPS $(1 \mu \mathrm{g} / \mathrm{ml})$, and MCP-1/CCL2 protein in the supernatants of cultured glial cells assessed by ELISA (C), after $24 \mathrm{H}$ treatment with either IL1 $\beta$ or LPS. IL1 $\beta$ mRNA was induced after 1 and $6 \mathrm{H}$ treatment with LPS, and MCP-1/ccl2 mRNA was induced after $6 \mathrm{H}$ treatment with either IL1 $\beta$ or LPS. As a result, MCP-1/CCL2 protein was increased in primary glial cultures after IL1 $\beta$ or LPS treatment. D, E, F: Histograms showing qRT-PCR levels of mRNAs 
encoding NTSR2 (D), and the other NT receptors, Sortilin1/NTSR3 (Sort1, E) and NTSR1 (F), after 1, 6 and 24H treatment with either IL1 $\beta$ or LPS. NTSR2 and NTSR3 mRNAs were induced after $1 \mathrm{H}$ treatment with IL1 $\beta$ or LPS, while NTSR1 mRNA levels were not modulated. These results show that NTSR2 and NTSR3 are upregulated in primary glial cells during inflammation and that inflammation modulated differentially the expression levels of the NT receptors. Values for $A, B, D, E, F$ are given as the mean \pm SEM normalized to CTL. Asterisks indicate statistically significant differences: * $p<0,05, * * p<0,01$ (one-way ANOVA followed by Tukey's post hoc test).

Figure 10. The rapid induction by inflammation of mRNAs encoding neurotensin receptors is independent of de novo protein synthesis in glial primary cultures. Plots on the left side illustrate the modulation of mRNA levels of the Zif-268/erg-1 IEG (A) and neurotensin receptors, NTSR2 (B) and Sort1/NTSR3 (C) at 1, 6 and 24H after treatment with LPS, CHX or LPS + CHX. LPS alone induced moderate to strong, rapid and transient expression of Zif268/egr-1, NTSR2 and Sort1/NTSR3 mRNA with a peak occurring at the 1H time point when compared to untreated glial cells. Histograms on the right side illustrate Zif-268/erg-1, NTSR2 and Sort1/NTSR3 mRNA expression after 1H treatment with LPS, CHX or LPS + CHX. Treatment with cycloheximide $(\mathrm{CHX}, 10 \mu \mathrm{g} / \mathrm{ml})$ induced the expression of Zif-268/erg-1, compared to untreated CTL glial cells and LPS treatment. However, CHX alone did not affect the expression of NTSR2 and Sort1/NTSR3 compared to LPS. When LPS was combined to CHX, super-induction was observed for Zif-268/erg-1 but not for NTSR2 and Sort1/NTSR3 as compared to LPS and CHX. Thus, as for IEG Zif-268/egr-1, the rapid and transient kinetics of activation and the absence of inhibition of NTSR2 and NTSR3 mRNA expression by CHX, suggest that NTSR2 and NTSR3 are new IEGs in rat primary glia. Values are given as the mean \pm SEM normalized to CTL. Asterisks indicate statistically significant differences: ${ }^{*} p<0,05, * *$ $p<0,01$ (one-way ANOVA followed by Tukey's post hoc test).

Figure 11. The vectorized NT analog VH-N412 down-regulates NTSR2 and GFAP protein expression in primary glial cultures. Representative images of NTSR2 and GFAP staining in untreated primary cultures of glial cells $(C T L)$ or after $24 \mathrm{H}$ treatment with VH-N412 $(1 \mu \mathrm{M})$, IL1 $\beta$, IL1 $\beta+$ VH-N412, LPS, or LPS + VH-N412 (A). Merge corresponds to superimposition of NTSR2 and GFAP staining. In (B), histograms comparing the average fluorescence intensity of 
NTSR2 in astrocytes after treatment with VH-N412, IL1 $\beta$, IL1 $\beta+$ VH-N412, LPS, or LPS + VHN412 compared to untreated CTL astrocytes, and comparison between the different treatments. Quantitative analysis showed that the NT analogue VH-N412 significantly decreased NTSR2 protein expression to CTL levels after $24 \mathrm{H}$ IL1 $\beta$ treatment in GFAP+ astrocytes. However, VH-N412 did not affect NTSR2 protein expression after 24H LPS treatment in GFAP+ astrocytes. In (C), histograms comparing the average fluorescence intensity of GFAP in astrocytes after treatment with VH-N412, IL1 $\beta$, IL1 $\beta+$ VH-N412, LPS, or LPS + VH-N412, compared to untreated CTL astrocytes, and comparison between the different treatments. Quantitative analysis showed that VH-N412 alone significantly decreased GFAP protein expression compared to untreated CTL astrocytes. However, VHN412 did not affect GFAP protein expression after 24H IL1 $\beta$ treatment in GFAP+ astrocytes. Finally, VH-N412 significantly decreased GFAP protein expression back to CTL levels after 24H LPS treatment in GFAP+ astrocytes compared to LPS alone-treated cells. Values are given as the mean \pm SEM as a percentage of CTL. Asterisks indicate statistically significant differences: * $p<0,05,{ }^{* *} p<0,01$ (one-way ANOVA followed by Tukey's post hoc test).

\section{Figure 12. The vectorized NT analog VH-N412 down-regulates NTSR2 and Iba1 protein} expression in primary glial cells. Representative images of NTSR2 and Iba1 staining in untreated primary cultures of glial cells $(C T L)$ or after $24 \mathrm{H}$ treatment with VH-N412 $(1 \mu \mathrm{M})$, IL1 $\beta$, IL1 $\beta+$ VH-N412, LPS, or LPS + VH-N412 (A). Merge corresponds to superimposition of NTSR2 and Iba1 staining. In (B), histograms comparing the average fluorescence intensity of NTSR2 in Iba1-positive microglia after treatment with VH-N412, IL1 $\beta$, IL1 $\beta$ + VH-N412, LPS, or LPS + VH-N412, compared to untreated CTL Iba1-positive microglia, and comparison between the different treatments. Quantitative analysis showed that VH-N412 significantly decreased NTSR2 protein expression back to CTL levels after 24H IL1 $\beta$ or LPS treatment in Iba1+ microglia. In (C), histograms comparing the average fluorescence intensity of Iba1 in microglia after treatment with VH-N412, IL1 $\beta, I L 1 \beta+$ VH-N412, LPS, or LPS + VH-N412, compared to untreated CTL astrocytes, and comparison between the different treatments. Quantitative analysis showed that VH-N412 significantly decreased Iba1 protein expression back to CTL levels after $24 \mathrm{H}$ IL1 $\beta$ or LPS treatment in Iba1+ microglia. Values are given as the mean \pm SEM as a percentage of CTL. Asterisks indicate statistically significant differences: * $p<0,05, * * p<0,01$ (one-way ANOVA followed by Tukey's post hoc test). 
Figure S1. NTSR2 expression is increased in mice hippocampus following KA-induced SE. NTSR2 (green) and MAP2 (red) double immunolabeling was performed in control (CTL, A-C, G-I) and KA-treated mice at day 7 post-SE (KA 7D, D-F, J-L). High magnifications of the hilus of CTL (G-I) and KA 7D (J-L) are shown. In CTL, NTSR2 immunolabeling is clearly shown in neurons, identified by MAP2 staining (see arrows and insets). In KA 7D, NTSR2 immunolabeling is strongly increased in cells that are not immunolabeled for MAP2, compared to CTL mice. NTSR2 immunoreactivity was observed in non-neuronal cell bodies and processes (see insets), likely astrocytes. Panels $\mathrm{C}, \mathrm{F}, \mathrm{I}$ and $\mathrm{L}$ correspond to superimposition of NTSR2, MAP2 and DAPI. Cell nuclei were counterstained with DAPI (blue, $\mathrm{C}, \mathrm{F}, \mathrm{I}, \mathrm{L})$ that underlined the different areas of the hippocampus and its deformation and degeneration that occur in the KA model of epilepsy. Scale bars: $450 \mu \mathrm{m}$ in A-F, $10 \mu \mathrm{m}$ in G-L and $5 \mu \mathrm{m}$ in insets. O: stratum oriens; P: pyramidal neurons of CA1, CA2 and CA3; R: stratum radiatum; LM: stratum lacunosum-moleculare; M: molecular layer; DG: dentate gyrus; G granule cells of DG; H: hilus of DG.

Figure S2. NTSR2 expression is increased in mice blood vessels following KA-induced SE. NTSR2 (green) immunostaining was performed in CTL (A-C) and KA-treated mice at day 7 post-SE (KA 7D, D-F). In KA 7D, NTSR2 immunoreactivity was increased in blood vessel cells of the lacunosum moleculare (LM) compared to CTL mice. In addition, several cells around these vessels displayed moderate to strong NTSR2 expression compared to CTL mice (arrowheads). Other dispersed cells in LM expressing NTSR2 were distinguished, projecting their processes (indicated by arrows and asterisks) around the blood vessels, similar to observations in blood vessels of pilocarpine rats. Cell nuclei were counterstained with DAPI (blue, $A, C, D, F)$. Scale bar: $20 \mu \mathrm{m}$ in all panels. 


\section{TABLE 1}

Primary antibodies used for immunofluorescence analysis

\begin{tabular}{|l|l|l|l|}
\hline Antibodies & Species & Sources and references & Dilution \\
\hline NTSR2 & Rabbit & Novus Biologicals, NBP1-00959 & $1: 100$ \\
\hline GFAP & Rabbit & Dako, Z0334 & $1: 500$ \\
\hline Iba1 & Rabbit & Wako, 019-19741 & $1: 500$ \\
\hline PDGFR & Rabbit & Abcam, ab32570 & $1: 100$ \\
\hline Collagen IV & Goat & Southern Biotech, 1340-01 & $1: 250$ \\
\hline CD31 & Mouse & Abcam, ab64543 & $1: 100$ \\
\hline MAP2 & Chicken & Abcam, ab5392 & $1: 500$ \\
\hline
\end{tabular}




\section{TABLE 2}

Rat TaqMan probes used for QPCR analysis

\begin{tabular}{|l|l|l|}
\hline Gene name & Gene description & Probe ID \\
\hline Ntsr1 & Neurotensin receptor 1 & Rn01415846 \\
\hline Ntsr2 & Neurotensin receptor 2 & Rn00575514 \\
\hline Ntsr3/Sort1 & Neurotensin receptor 3/Sortilin 1 & Rn01521847 \\
\hline Mcp1/ccl2 & Monocyte Chemoattractant ligand 1 & Rn00580555 \\
\hline II1b & Interleukin 1 & Rn00580432 \\
\hline Gfap & Glial Fibrillary Acidic Protein & Rn01253033 \\
\hline Zif-268/egr1 & $\begin{array}{l}\text { Zinc finger protein 225/early growth response } \\
\text { protein 1 }\end{array}$ & Rn00561138 \\
\hline Gapdh & Glyceraldehyde-3-phosphate dehydrogenase & Rn01775763 \\
\hline
\end{tabular}


bioRxiv preprint doi: https://doi.org/10.1101/2020.06.29.166637; this version posted June 29, 2020. The copyright holder for this preprint (which was not certified by peer review) is the author/funder. All rights reserved. No reuse allowed without permission.

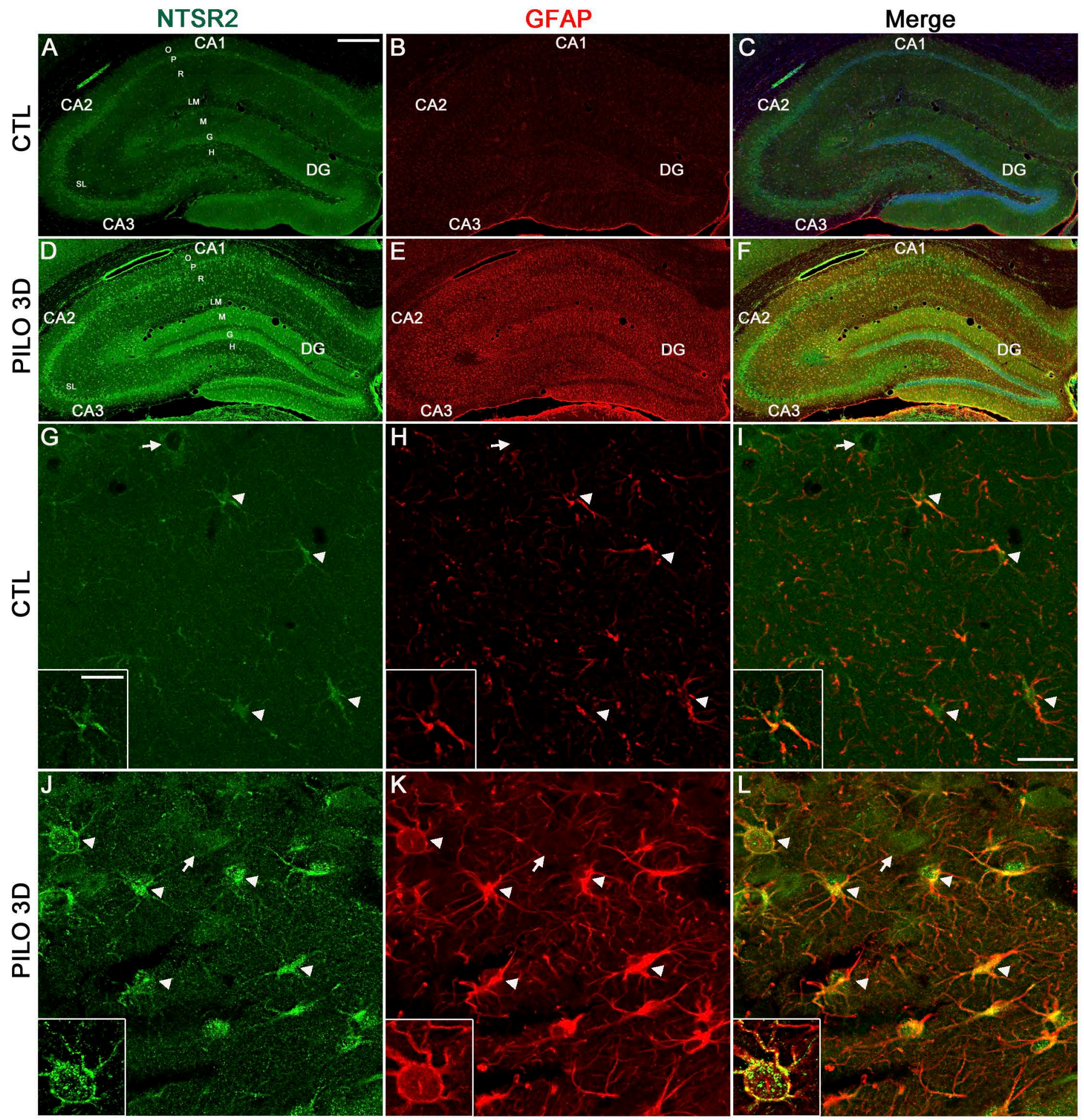

Figure 1 : Kyriatzis et al 
bioRxiv preprint doi: https://do[ $\mathrm{rg} / 10.1101 / 2020.06 .29 .166637$; this DGon posted June 29, 2020. The copyright holder for this preprint (which was not certified b150em review) is the author/funder. All rights reserved. No reuse allowed without permission.

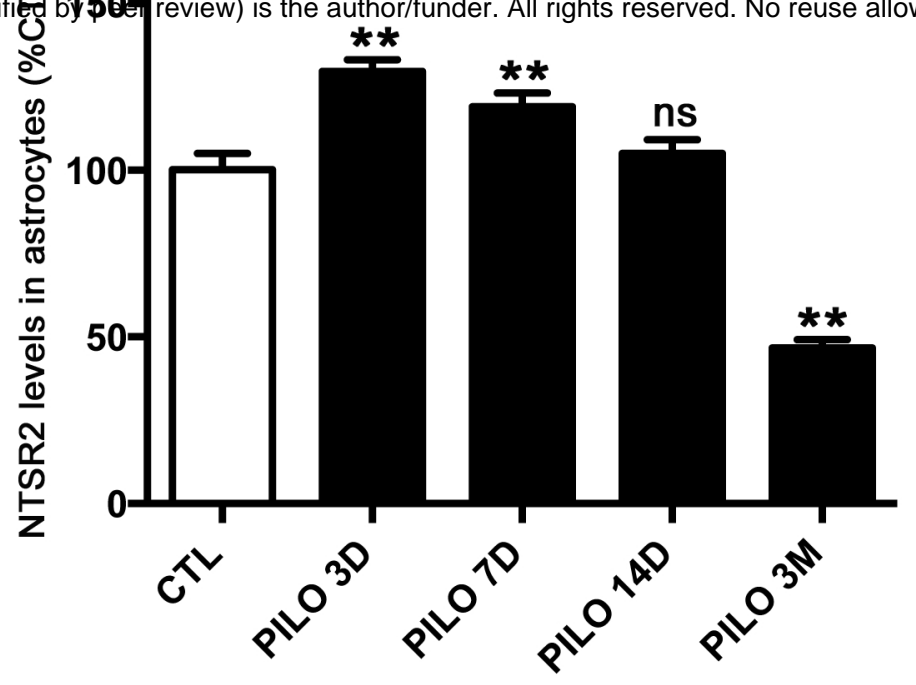

B

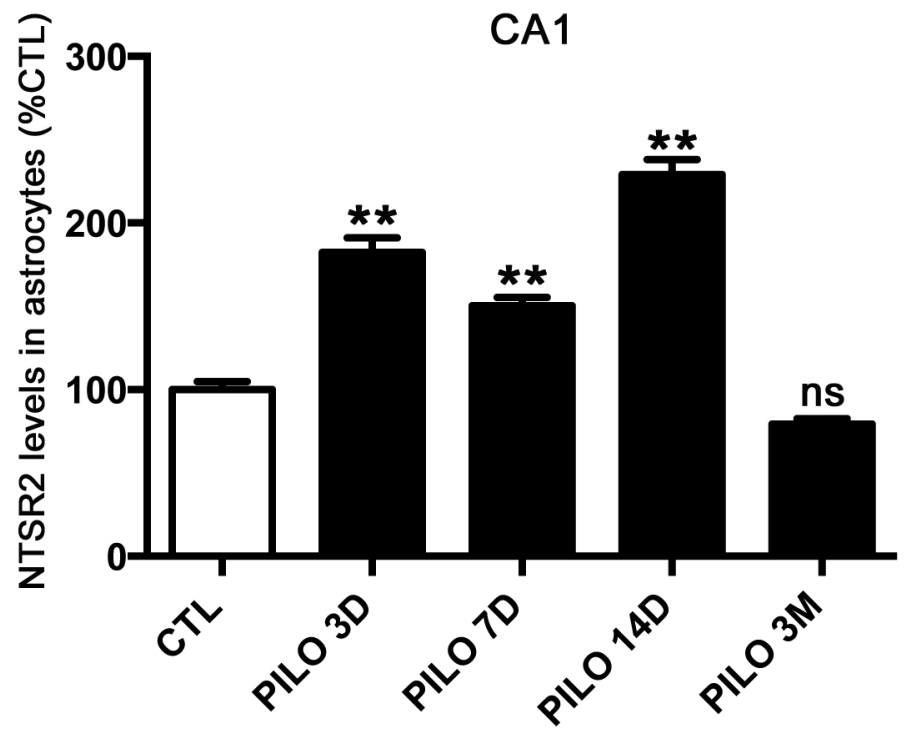

C

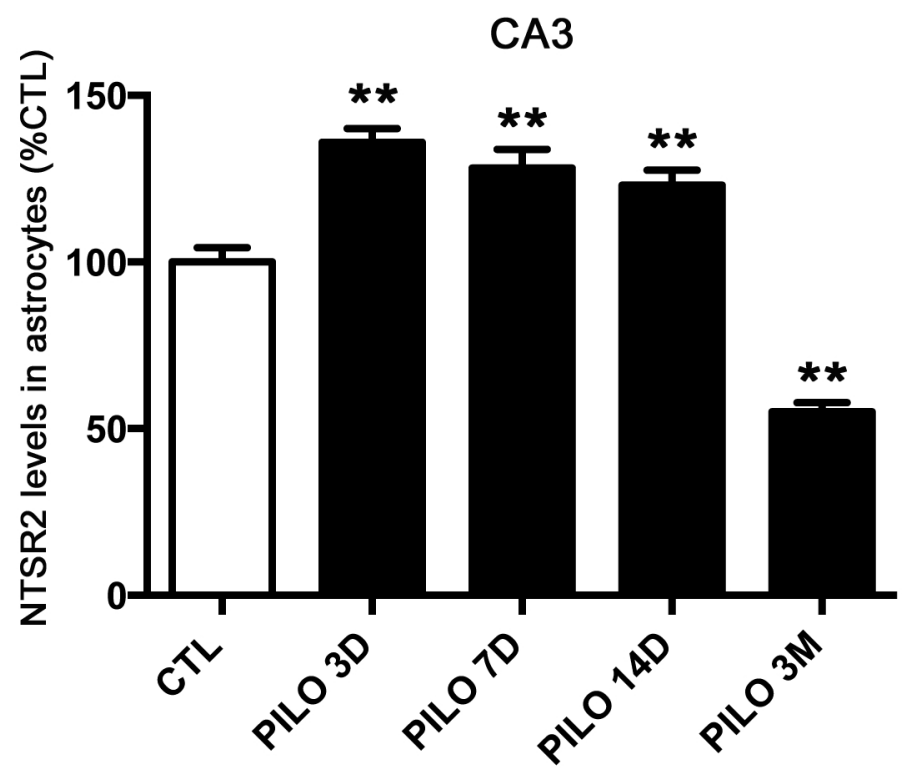

Figure 2 : Kyriatzis et al 
bioRxiv preprint doi: https://doi.org/10.1101/2020.06.29.166637; this version posted June 29, 2020. The copyright holder for this preprint (which was not certified by peer review) is the author/funder. All rights reserved. No reuse allowed without permission.

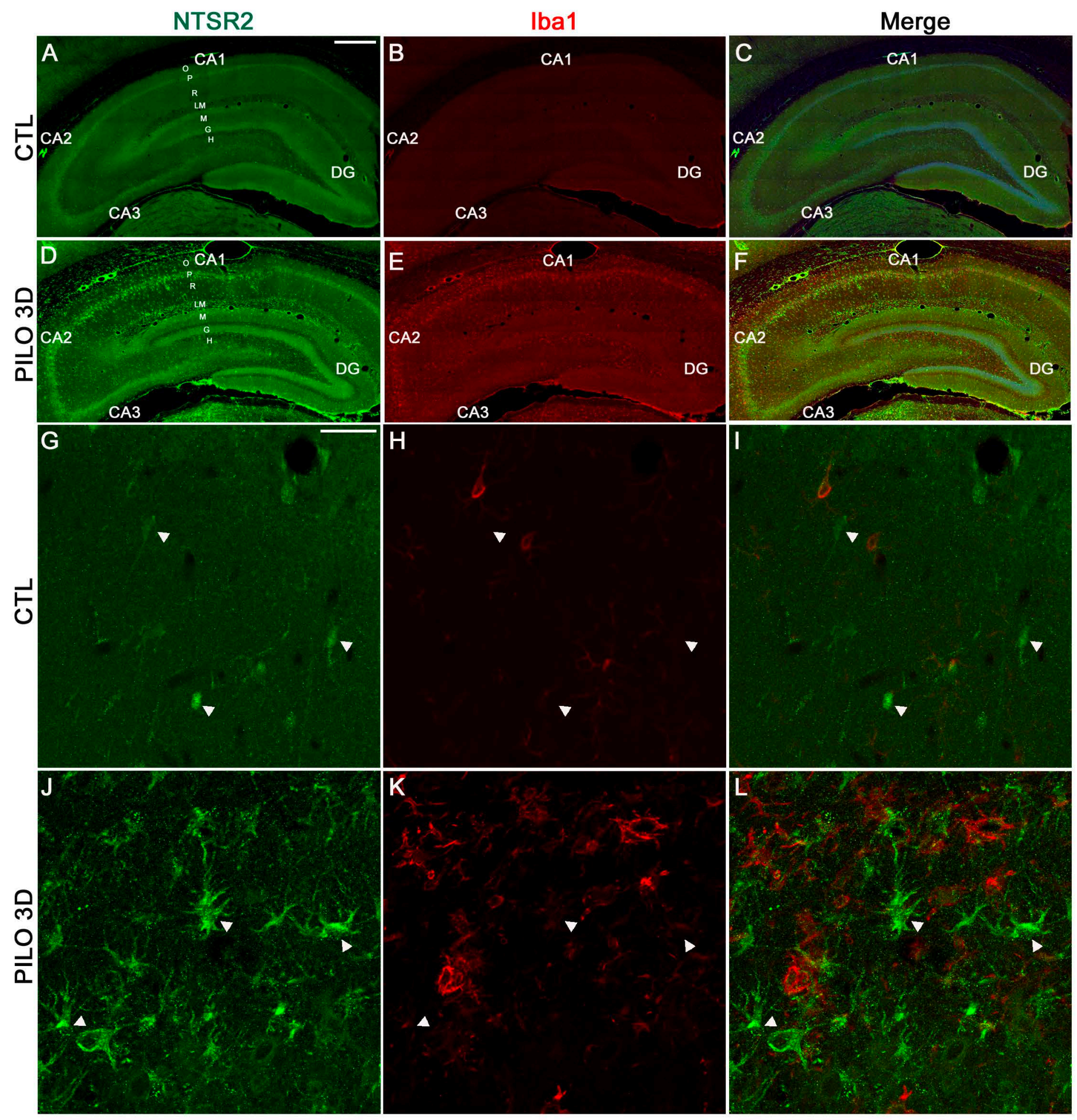

Figure 3 : Kyriatzis et al 


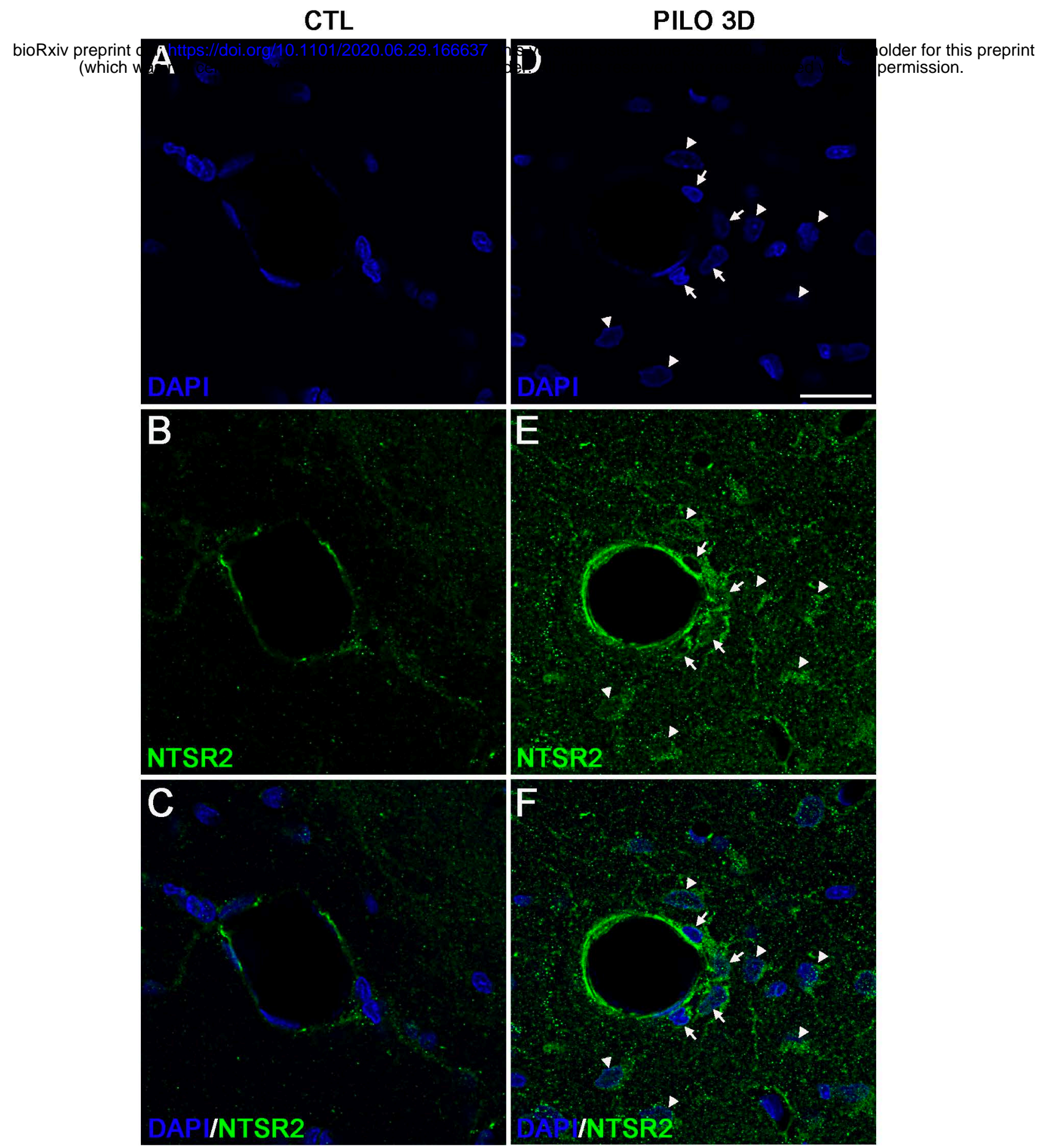

G

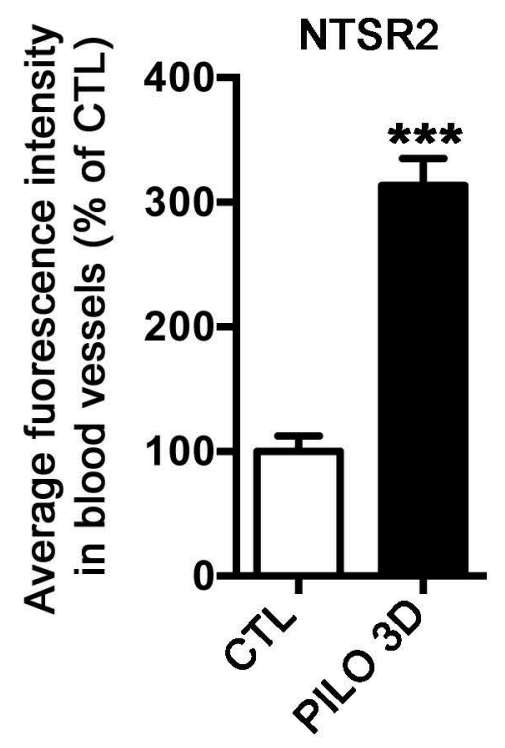

Figure 4 : Kyriatzis et al 
bioRxiv preprint doi: https://doi.org/10.1101/2020.06.29.166637; this version posted June 29, 2020. The copyright holder for this preprint (which was not certified by peer review) is the author/funder. All rights reserved. No reuse allowed without permission.
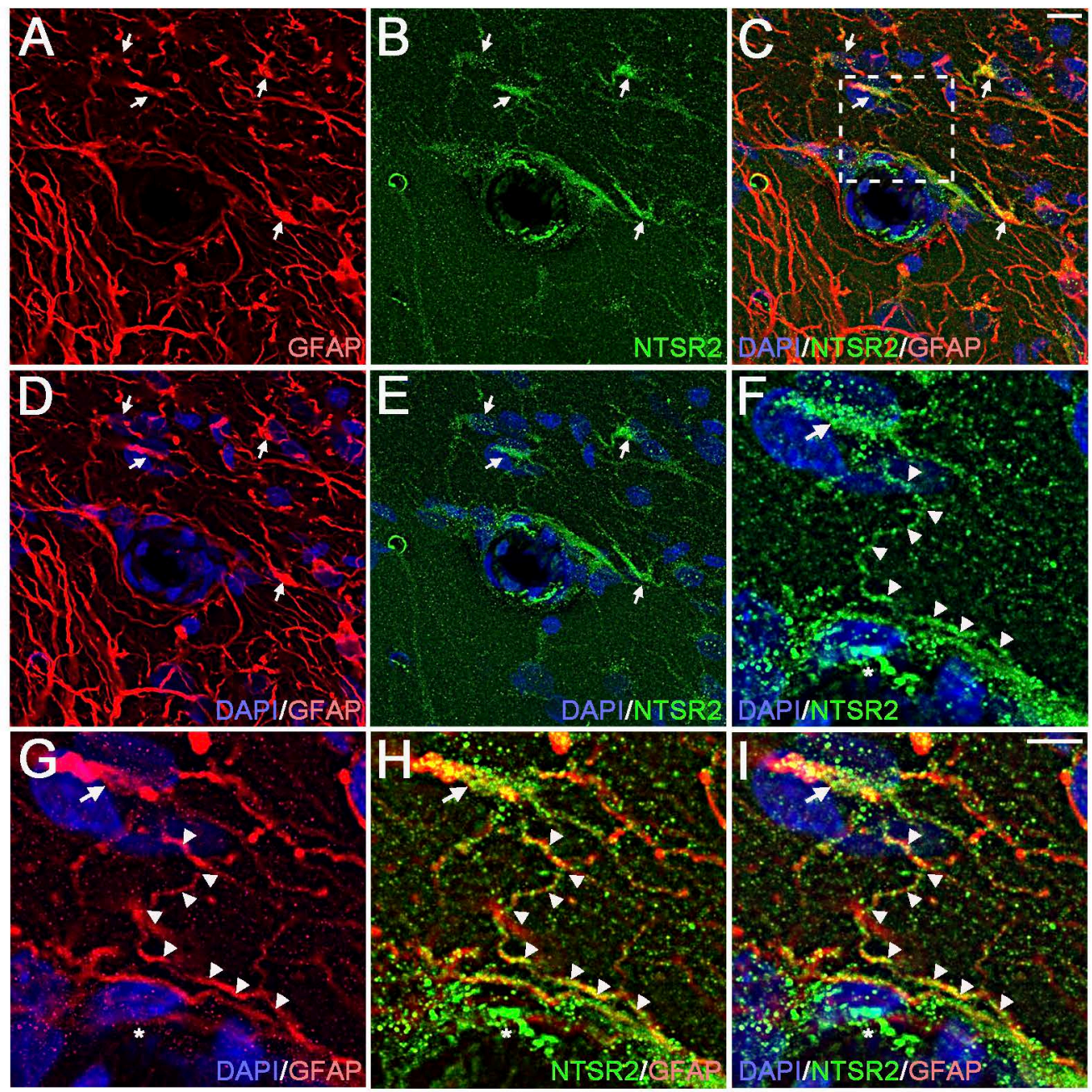

Figure 5 : Kyriatzis et al 
bioRxiv preprint doi: https://doi.org/10.1101/2020.06.29.166637; this version posted June 29, 2020. The copyright holder for this preprint (which was not certified by peer review) is the author/funder. All rights reserved. No reuse allowed without permission.
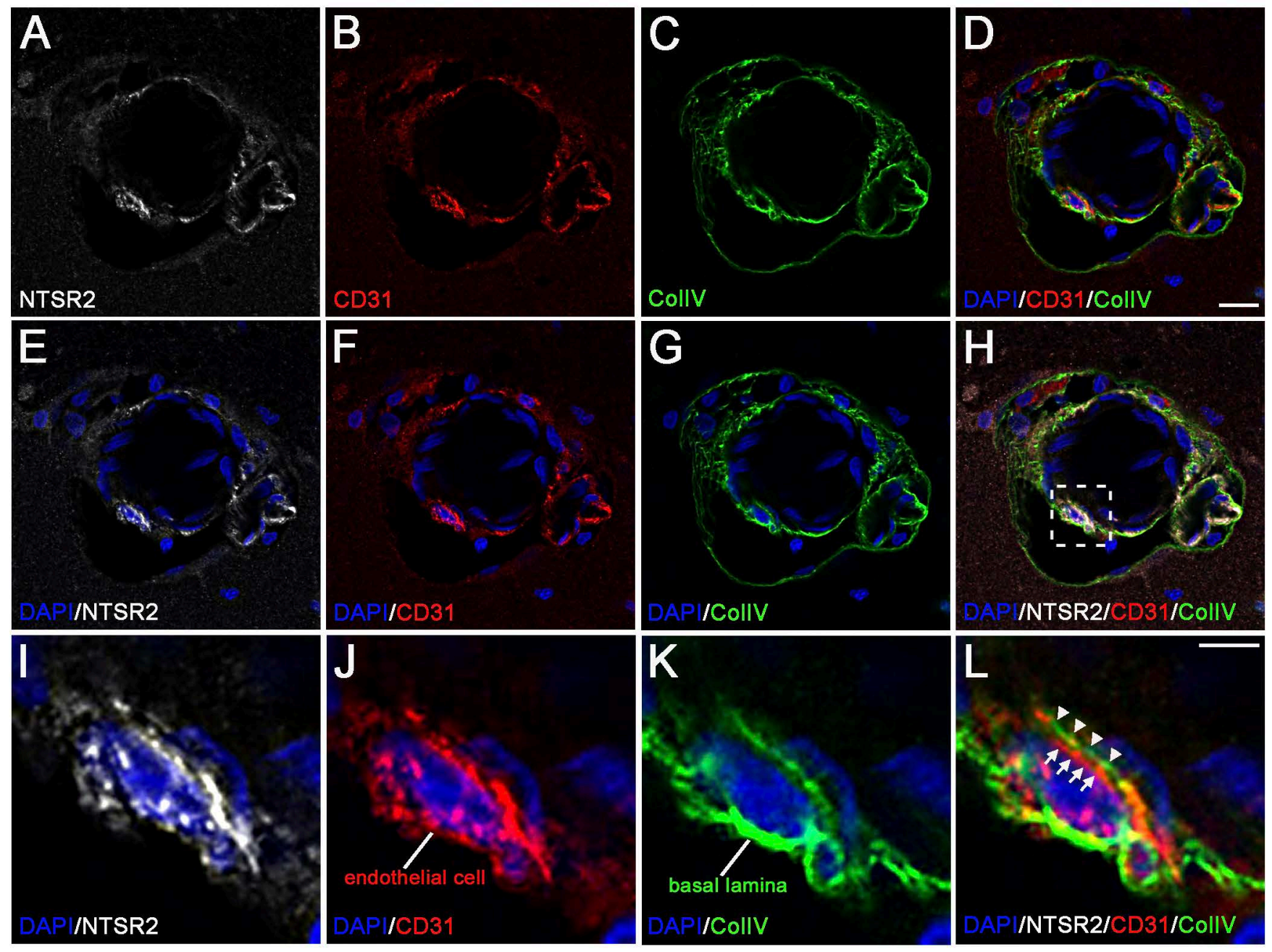

Figure 6 : Kyriatzis et al 
bioRxiv preprint doi: https://doi.org/10.1101/2020.06.29.166637; this version posted June 29, 2020. The copyright holder for this preprint (which was not certified by peer review) is the author/funder. All rights reserved. No reuse allowed without permission.

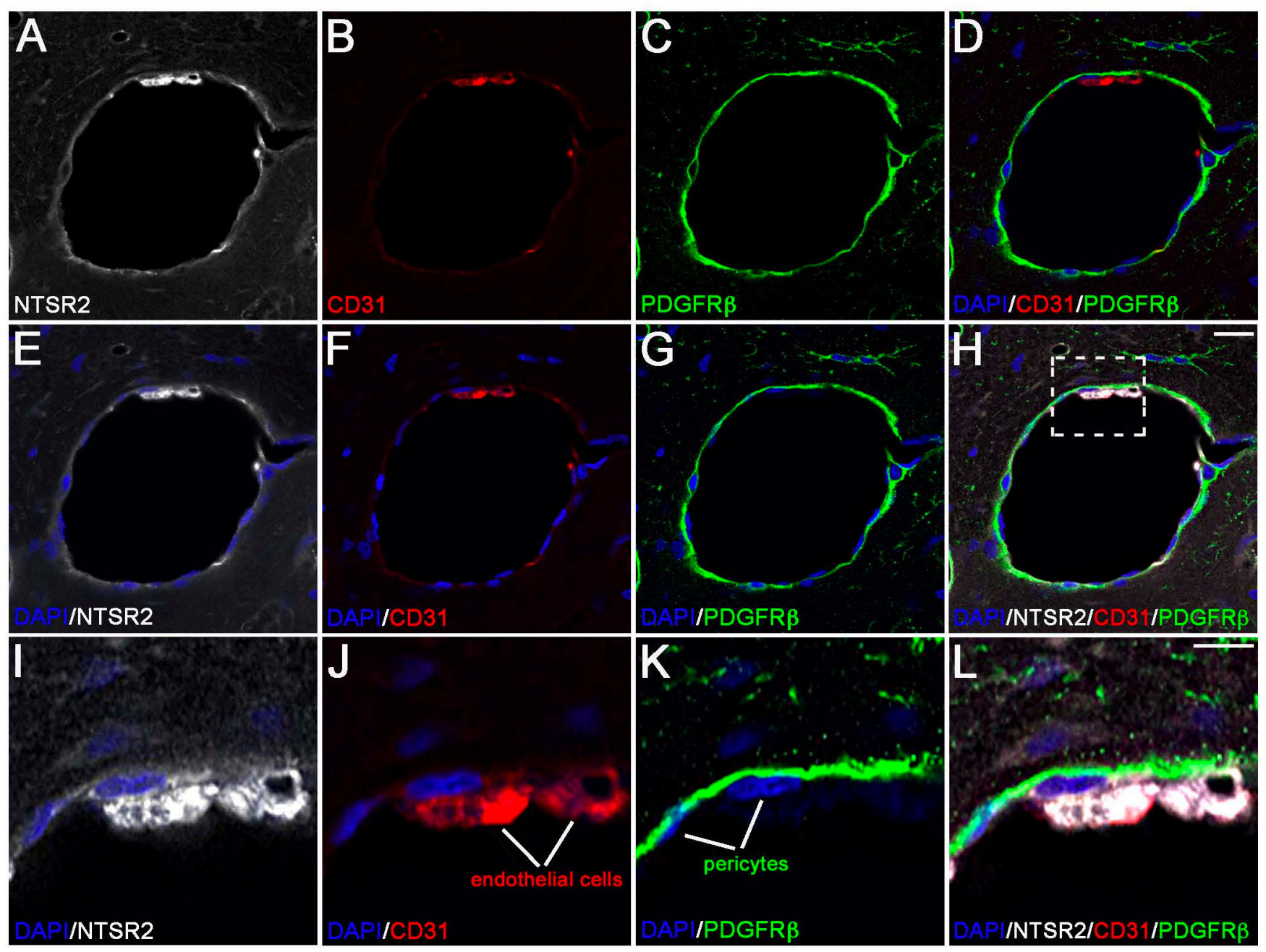

Figure 7 : Kyriatzis et al 


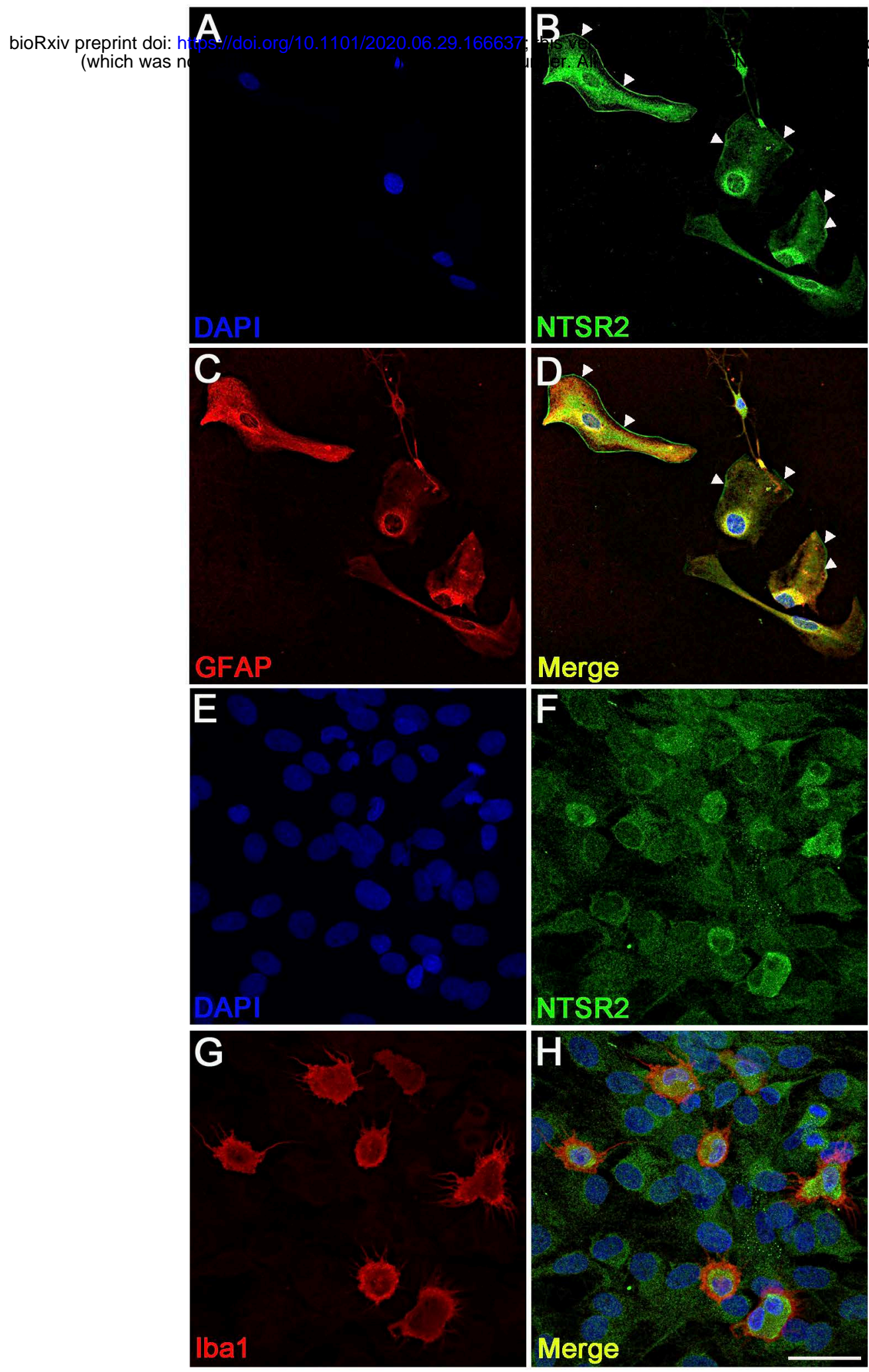

opyright holder for this preprint d without permission.

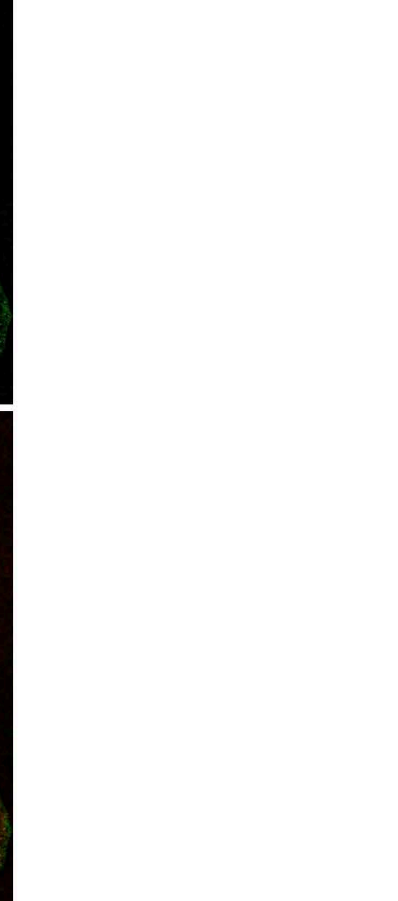


A

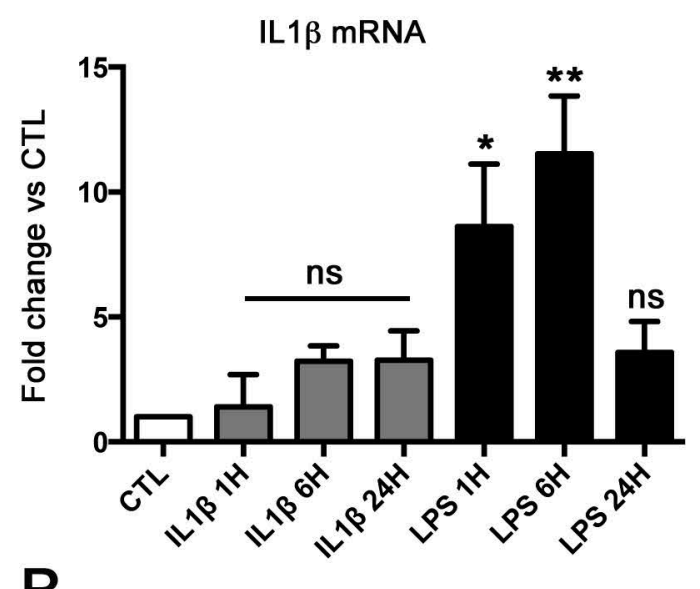

B

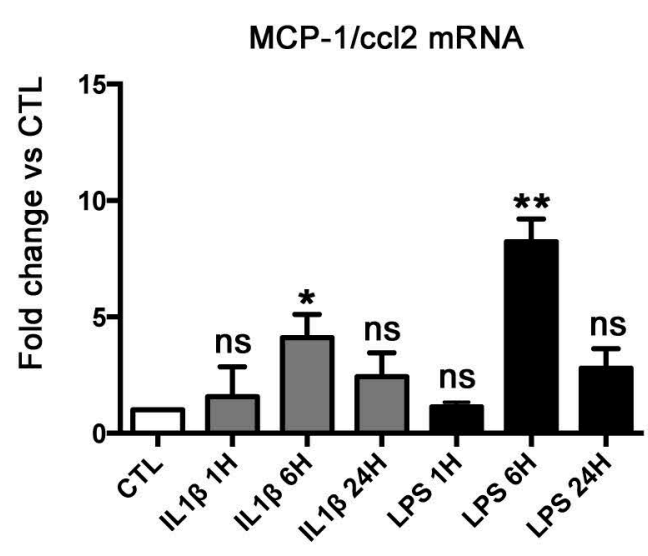

C

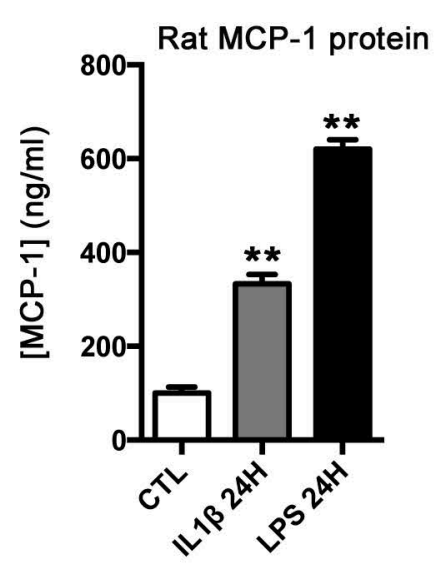

$\mathrm{D}$

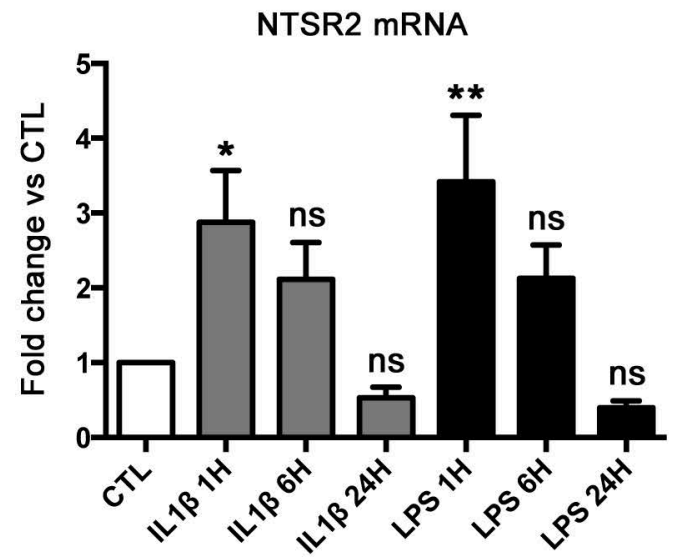

E

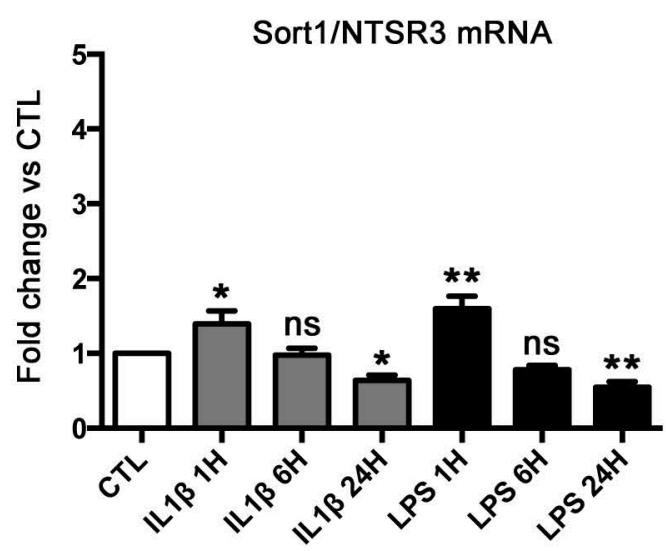

F

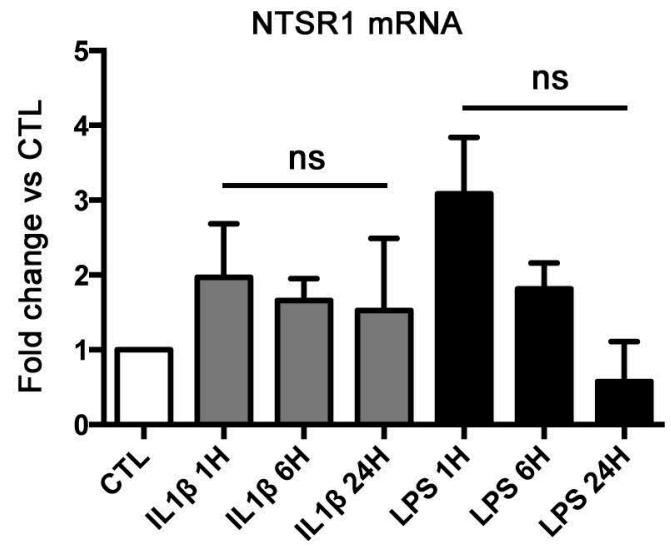

Figure 9: Kyriatzis et al. 
bioRxiv preprint doi: https://doi.org/10.1101/2020.06.29.166637; this version posted June 29, 2020. The copyright holder for this preprint (which was not certified by peer review) is the author/funder. All rights reserved. No reuse allowed without permission.

A Zif-268/erg-1 mRNA
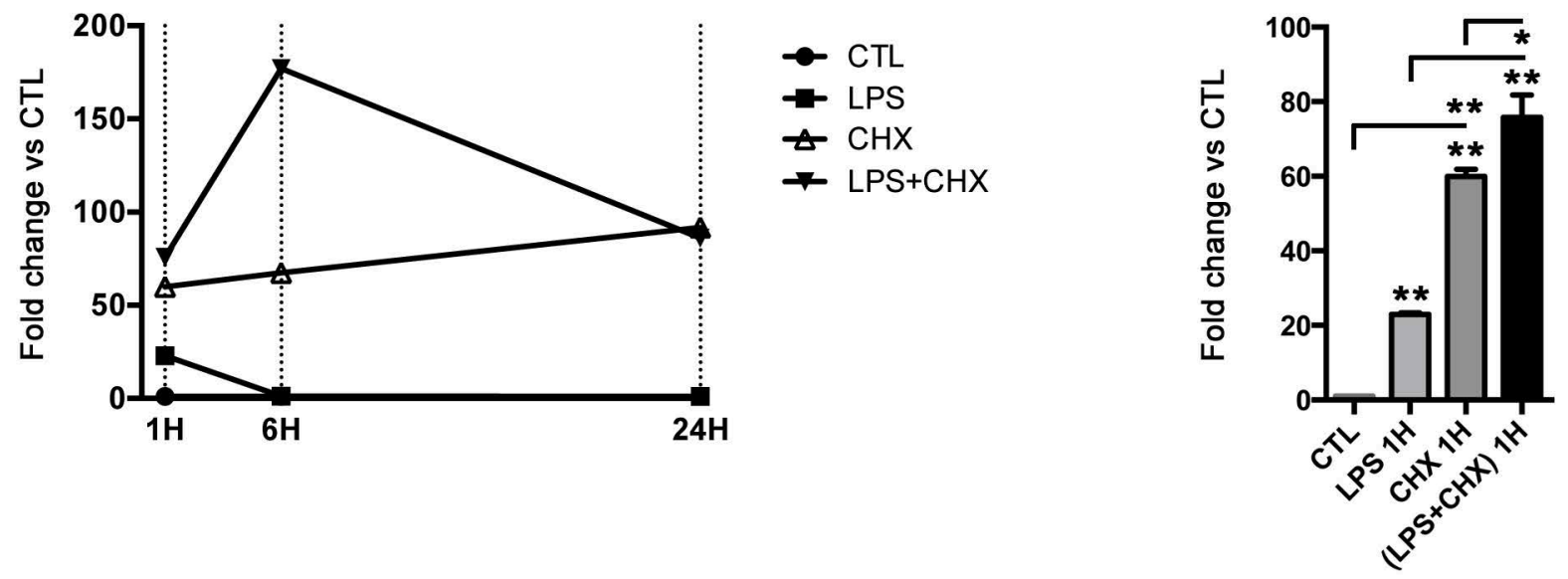

B

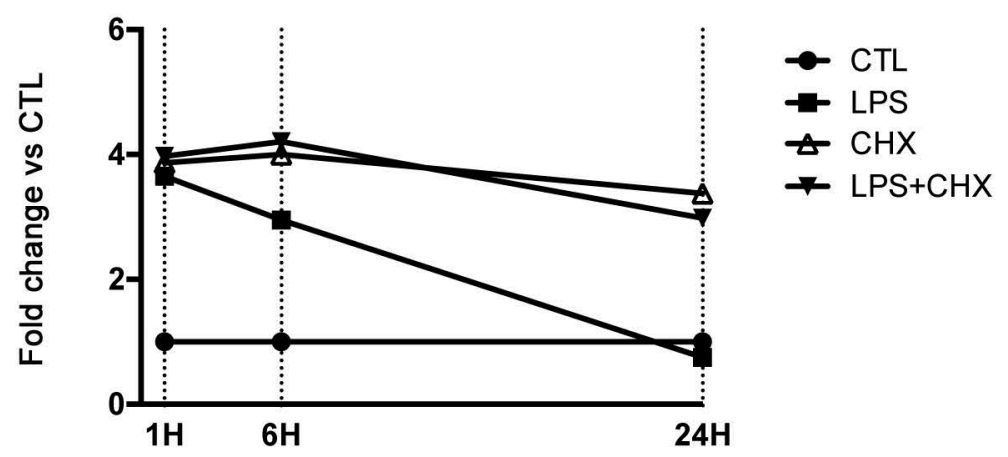

C

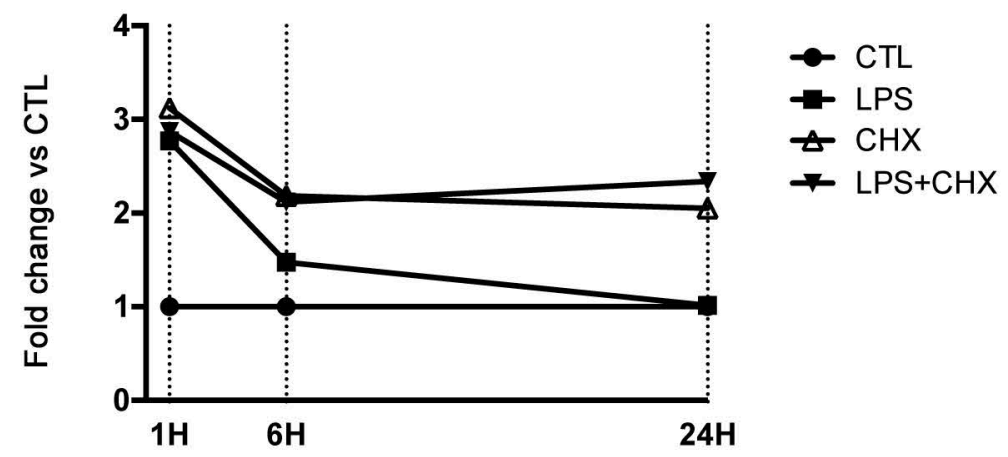

\section{NTSR2 mRNA}

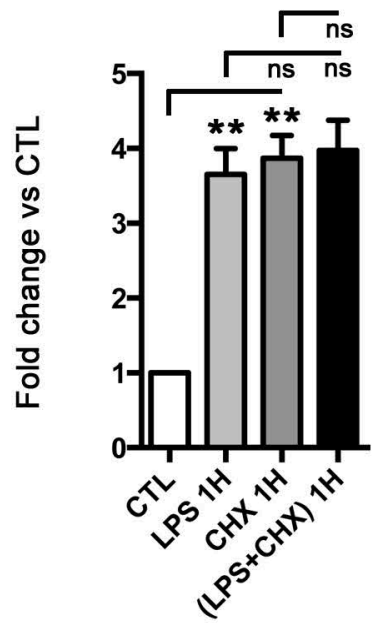

\section{Sort1/NTSR3 mRNA}

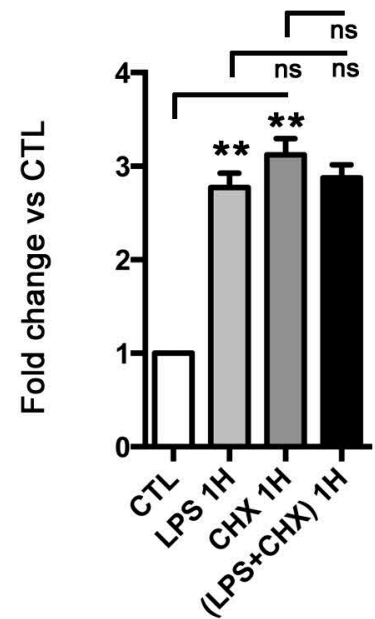

Figure 10: Kyriatzis et al 

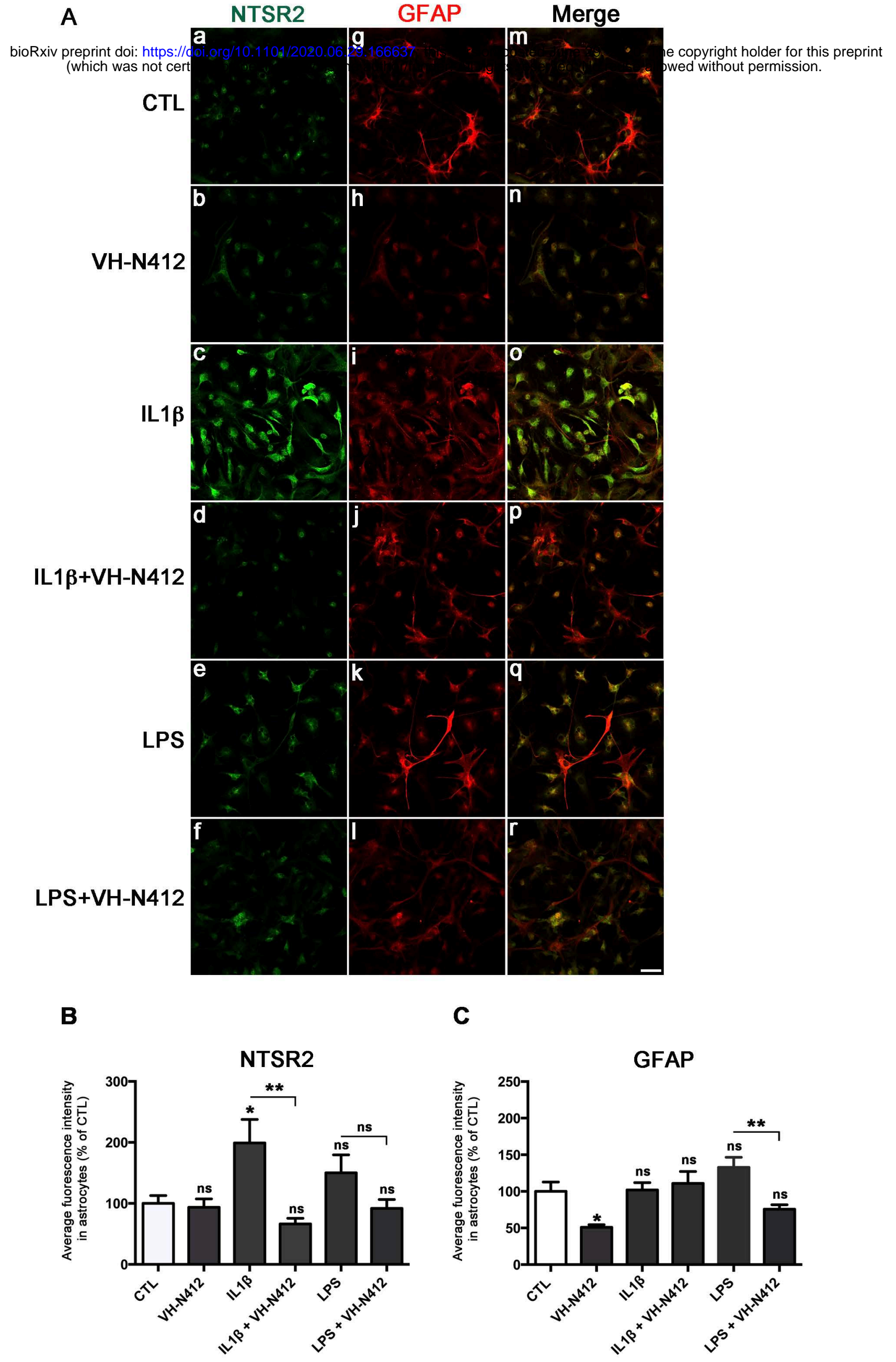

Figure 11 : Kyriatzis et al 
A

bioRxiv preprint doi: https://doi.o

(which was not certified

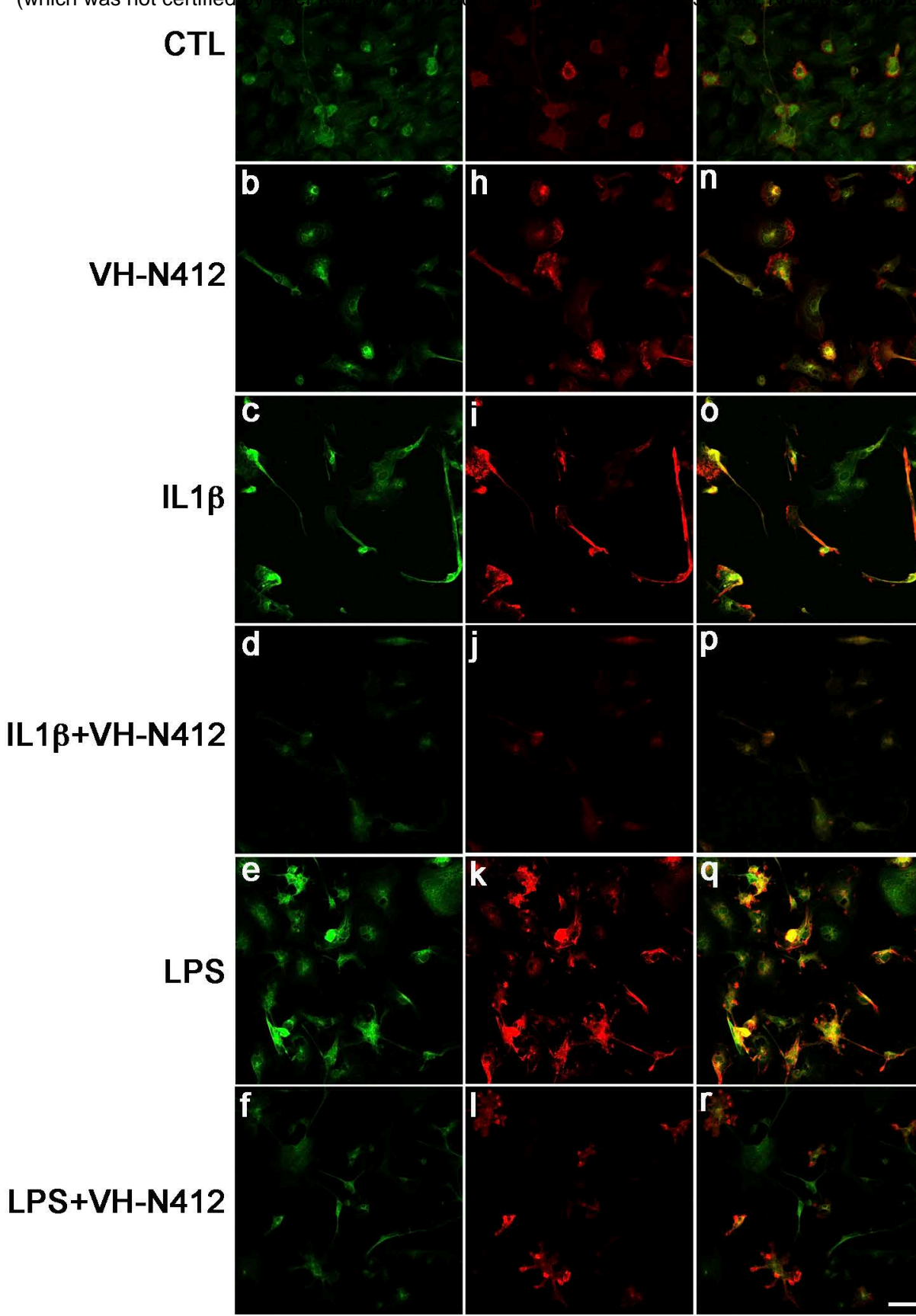

B

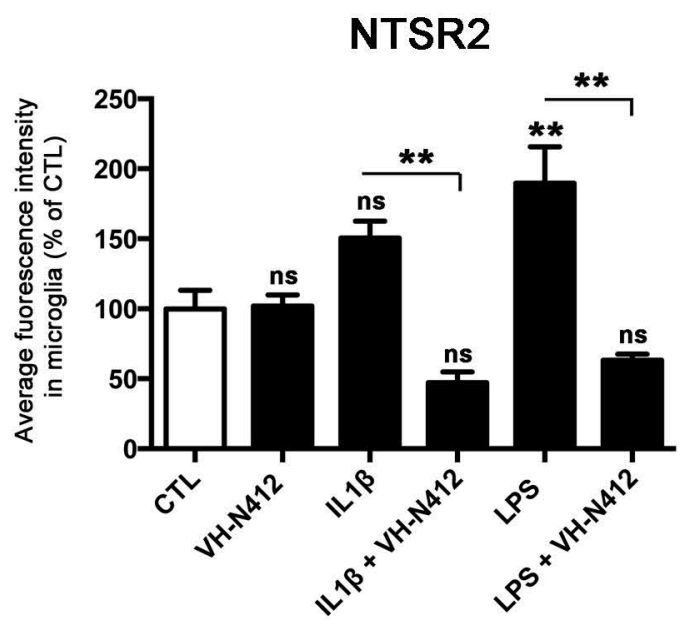

C

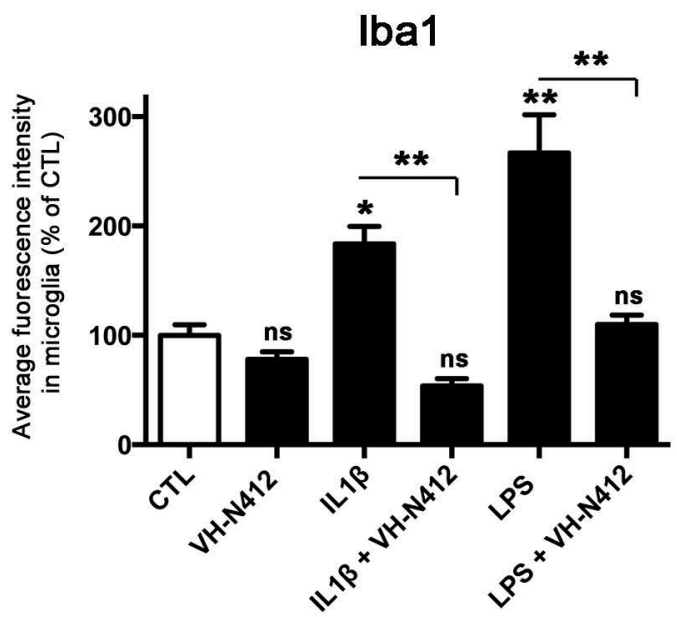

Figure 12 : Kyriatzis et al 


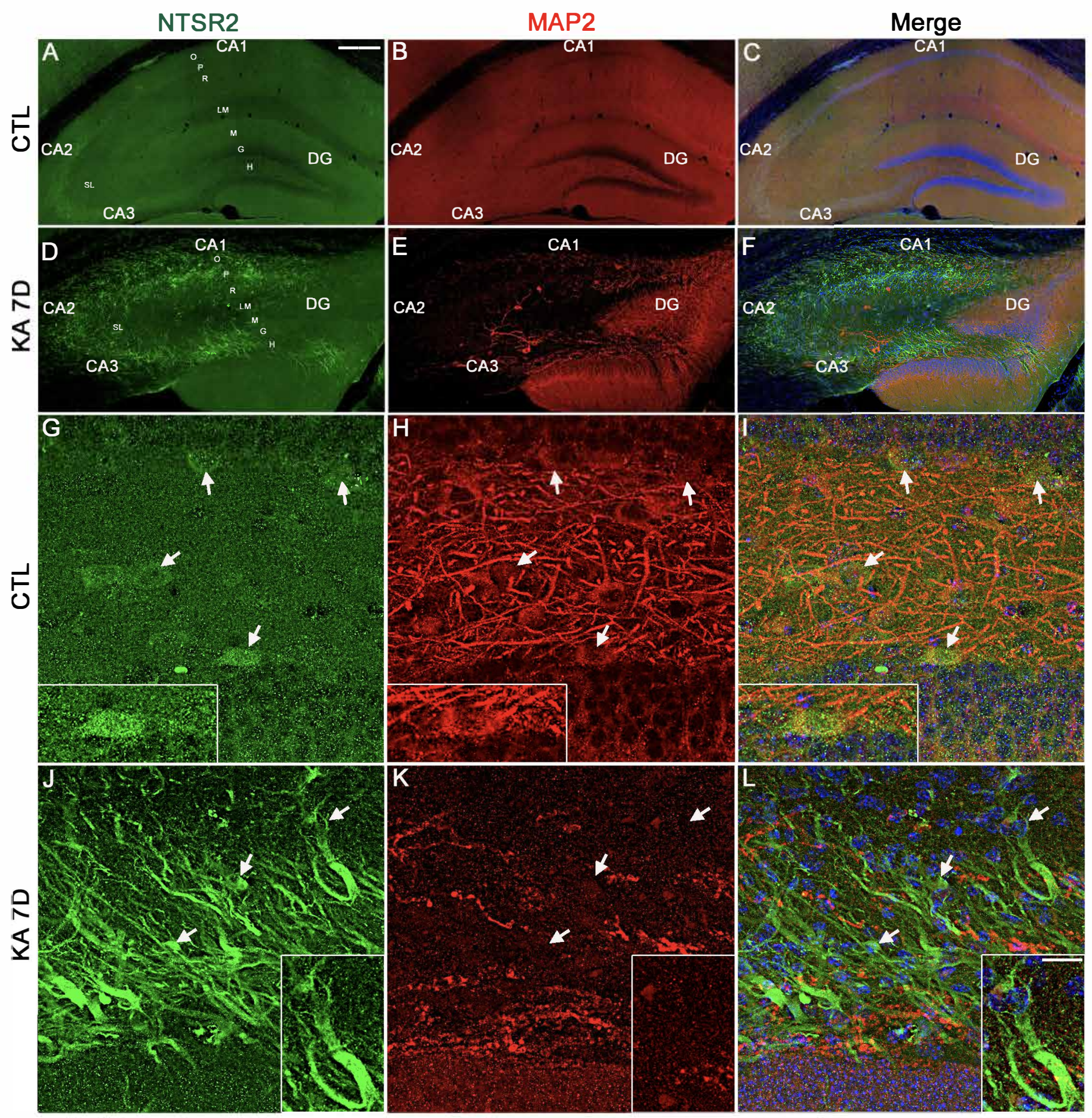

Supplemental Figure S1: Kyriatzis et al 


\section{CTL}
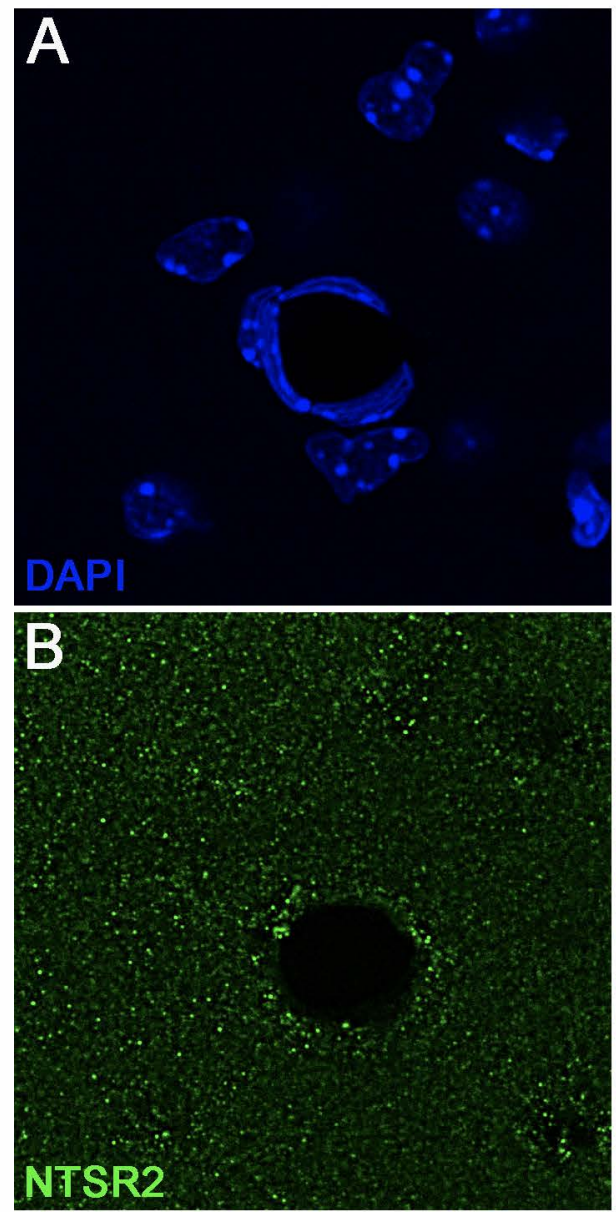

0

INTSR2
KA 7D
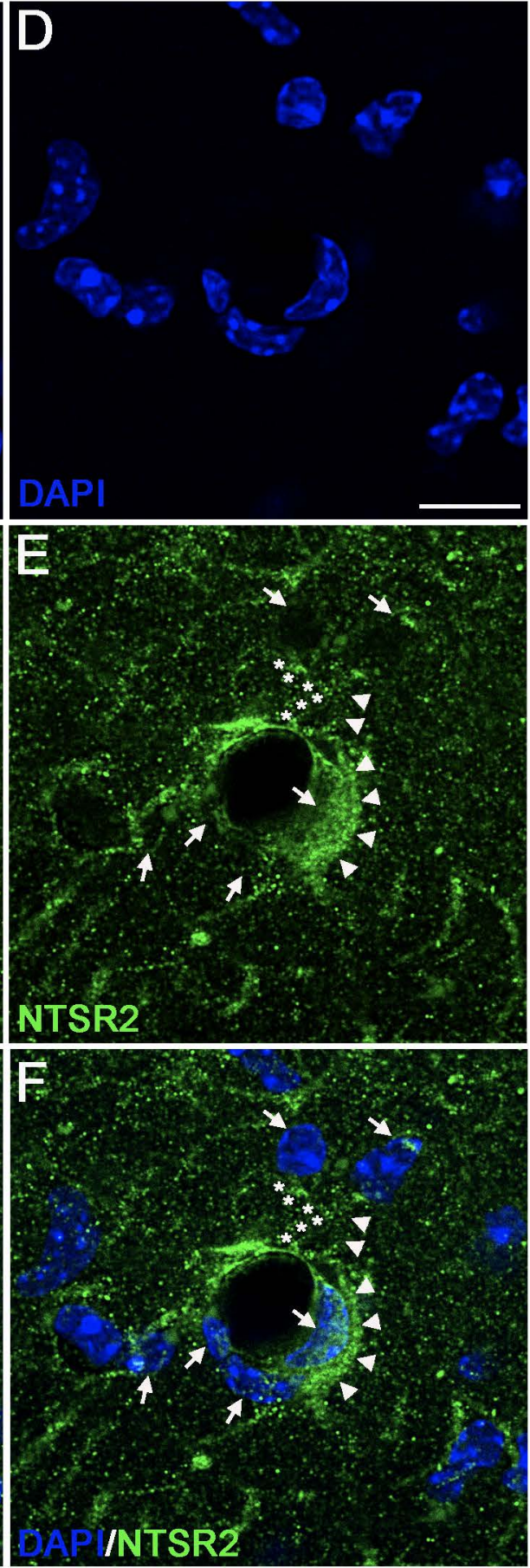

Supplemental Figure S2: Kyriatzis et al 